UNIVERSIDADE DE BRASÍLIA

FACULDADE DE CIÊNCIAS DA SAÚDE

PROGRAMA DE PÓS-GRADUAÇÃO EM ENFERMAGEM

MESTRADO EM ENFERMAGEM

THATIANE MARQUES TORQUATO

SIGNIFICADOS DA EXPERIÊNCIA DA AUTO

ADMINISTRAÇÃO DE INSULINA PARA PESSOAS QUE VIVEM COM DIABETES

BRASÍLIA - DF

2016 


\author{
UNIVERSIDADE DE BRASÍLIA \\ FACULDADE DE CIÊNCIAS DA SAÚDE \\ PROGRAMA DE PÓS-GRADUAÇÃO EM ENFERMAGEM \\ MESTRADO EM ENFERMAGEM
}

THATIANE MARQUES TORQUATO

\title{
SIGNIFICADOS DA EXPERIÊNCIA DA AUTO ADMINISTRAÇÃO DE INSULINA PARA PESSOAS QUE VIVEM COM DIABETES
}

Dissertação apresentada como requisito
parcial para a obtenção do Título de
Mestre em Enfermagem pelo Programa de
Pós-Graduação em Enfermagem da
Universidade de Brasília.
Área de Concentração: Políticas, práticas
e cuidado em saúde e enfermagem.
Linha de Pesquisa: Gestão de Sistemas e
de Serviços em Saúde e Enfermagem.

Orientadora: Prof. ${ }^{a}$ Dr. ${ }^{\text {a }}$ Walterlânia Silva Santos

BRASÍLIA - DF

2016 


\section{SIGNIFICADOS DA EXPERIÊNCIA DA AUTO ADMINISTRAÇÃO DE INSULINA PARA PESSOAS QUE VIVEM COM DIABETES}

Dissertação apresentada como requisito parcial para a obtenção do Título de Mestre em Enfermagem pelo Programa de Pós-Graduação em Enfermagem da Universidade de Brasília.

Área de Concentração: Políticas, práticas e cuidado em saúde e enfermagem.

Linha de Pesquisa: Gestão de Sistemas e de Serviços em Saúde e Enfermagem.

Aprovado em 27 de julho de 2016.

BANCA EXAMINADORA
Professora Doutora Walterlânia Silva Santos
Presidente da Banca
Universidade de Brasília- UnB

Professor Doutor Marcelo Medeiros

Membro Efetivo e Externo

Universidade Federal de Goiás - UFG

Professora Doutora Diana Lúcia Moura Pinho

Membro Efetivo e Interno

Universidade de Brasília - UnB

Professora Doutora Tania Cristina Morais Santa Barbara Rehem

Suplente

Universidade de Brasília - UnB 
FICHA CATALOGRÁFICA

TORQUATO,THATIANE MARQUES

Significados da experiência da auto administração de insulina para pessoas que vivem com diabetes, 2016, 103 p., 297 mm, (UnB-PPGEnf, Mestre, Enfermagem, 2016).

Dissertação de Mestrado - Universidade de Brasília. Programa de Pós-Graduação em Enfermagem.

1. Diabetes Mellitus

3. Atenção Primária a Saúde

I. UnB-PPGenf
2. Insulina

4. Enfermagem

II. Título (série)

\section{REFERÊNCIA BIBLIOGRÁFICA}

TORQUATO, T. M. Significados da experiência da auto administração de insulina para pessoas que vivem com diabetes. 2016. 103f. Dissertação (Mestrado em Enfermagem) - Universidade de Brasília, Brasília, 2016.

\section{CESSÃO DE DIREITOS}

É concedida à Universidade de Brasília permissão para reproduzir cópias desta dissertação e emprestar ou vender tais cópias somente para propósitos acadêmicos e científicos. A autora reserva outros direitos de publicação e nenhuma parte desta dissertação de mestrado pode ser reproduzida sem a sua autorização por escrito. 


\section{DEDICATÓRIA}

Dedico este trabalho aos meus pais, Luzeni e Djalma, e ao meu esposo Sandro. 


\section{AGRADECIMENTOS}

Agradeço primeiramente a DEUS, pela dádiva da vida e por, em momentos aflitos, proporcionar-me sua paz e serenidade para enfrentar os obstáculos e superar os desafios.

Aos meus pais, DJALMA e LUZENI, e às minhas queridas irmãs THIARA, THIANE e DIANDRA, que representam meu porto seguro e, mesmo de longe, apoiaram-me em todos os momentos, ajudando-me e incentivando durante toda a minha jornada.

Ao meu querido esposo SANDRO, pelo carinho, amor, paciência, cuidado, incentivo, e por me proporcionar o sonho de ser mãe no final dessa trajetória.

Aos meus sobrinhos WOOD, YAN, YASMIM, TAYNARA E TAYNAN, pelo carinho e amor.

À professora WALTERLÂNIA, por ter-me orientado e conduzido essa pesquisa com imensa competência e seriedade.

Aos amigos de trabalho do Instituto Federal de Goiás, SUENIR, DANI, NILSON, WAGNER, pela confiança, incentivo e carinho demonstrados por mim durante essa árdua caminhada.

Aos colegas do mestrado, pela boa convivência e pelas discussões.

Ao corpo docente da Pós-Graduação em Enfermagem da UnB, pelos ensinamentos.

Por fim, às PESSOAS COM DIABETES que disponibilizaram seu tempo para participar desta pesquisa como voluntários. Muito obrigada! Sem dúvida, a participação de vocês neste estudo subsidiará os cuidados futuros de outros indivíduos diabéticos.

Ninguém faz nada sozinho! Obrigada pela ajuda e incentivo de cada um de vocês! 
"Tão importante quanto conhecer a doença que o homem tem, é conhecer o homem que tem a doença."

William Osler 


\section{SUMÁRIO}

LISTA DE FIGURAS ............................................................................................................... $\mathrm{x}$

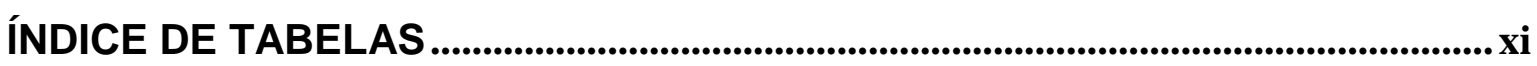

ÍNDICE DE QUADROS ...............................................................................................

LISTA DE ABREVIATURAS ...................................................................................................xiii

RESUMO_.......................................................................................................................................... $\mathrm{xV}$

ABSTRACT .......................................................................................................................

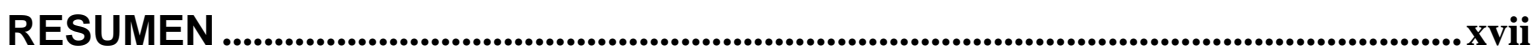

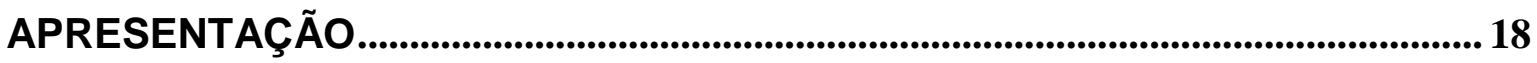

CAPÍTULO 1 - DELIMITANDO O OBJETO E OBJETIVO DO ESTUDO ................20

CAPÍTULO 2 - REVISÃO DA LITERATURA ................................................................. 24

2.1 - A EXPERIÊNCIA EM POSSUIR DIABETES E UTILIZAR INSULINA ..............24

2.2 - GESTÃO DO REGIME TERAPÊUTICO ……......................................................2

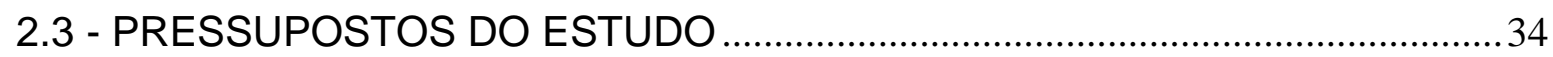

CAPÍTULO 3 - CAMINHO METODOLÓGICO ...............................................................35

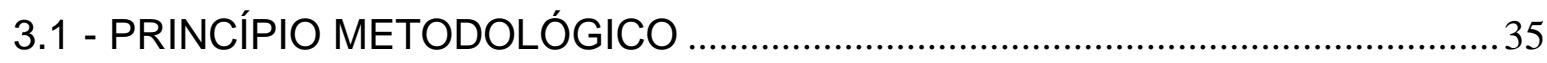

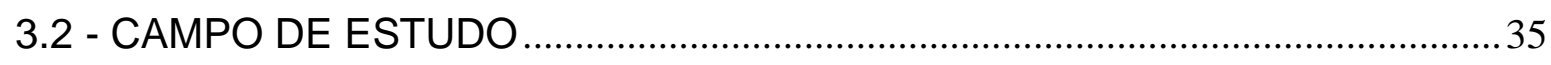

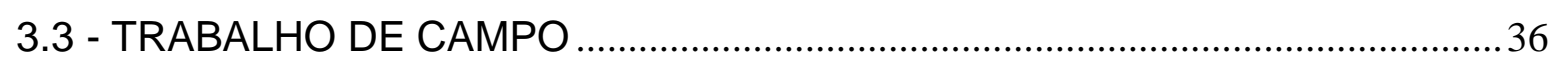

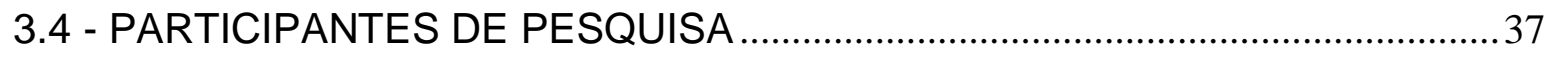

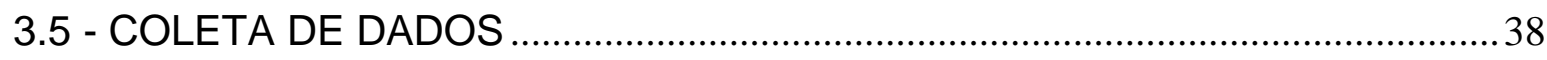

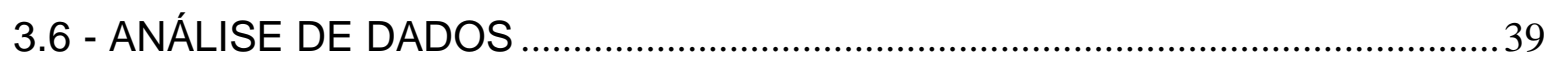

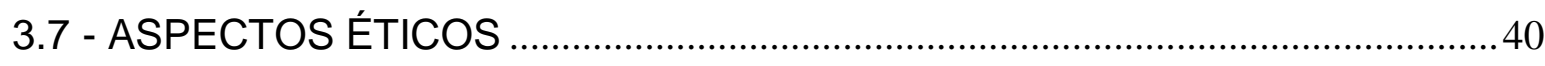

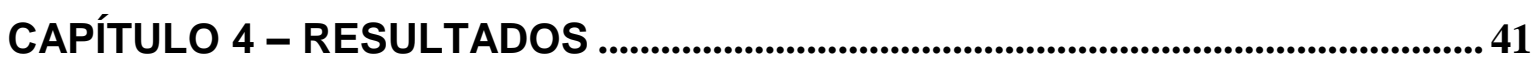

4.1 - CARACTERIZAÇÃO DOS PARTICIPANTES …………………………….......41

4.2 - A EXPERIÊNCIA DOS INSULINOTRATADOS EM VIVER COM A SUA CONDIÇÃO CRÔNICA E ADMINISTRAR A INSULINA ...............................................42

4.2.1 - A experiência dos diabéticos em viver com sua condição crônica ............ 42

4.2.2 - A insulinoterapia na visão dos diabéticos .....................................................46

4.3 - GESTÃO DO CUIDADO NO MANEJO DA INSULINA A.......................................48 


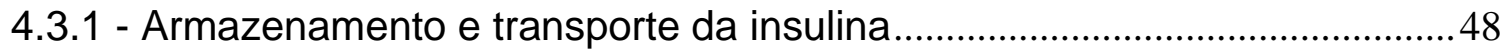

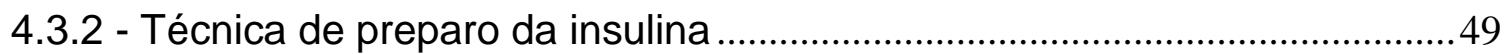

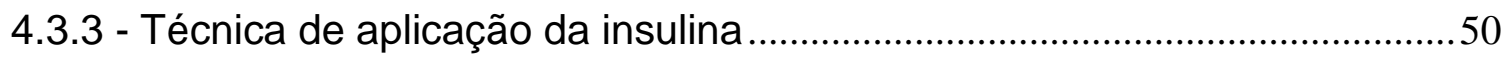

CAPÍTULO 5 - DISCUSSÃO ................................................................................................. 54

5.1 - CARACTERIZAÇÃO DOS PARTICIPANTES .................................................54

5.2 - A EXPERIÊNCIA DOS INSULINOTRATADOS EM VIVER COM A SUA CONDIÇÃO CRÔNICA E ADMINISTRAR A INSULINA ..........................................57

5.2.1 - A experiência dos diabéticos em viver com sua condição crônica ............57

5.2.2 - A insulinoterapia na visão de pessoas com diabetes..................................63

5.3 - A GESTÃO DO CUIDADO NO MANEJO DA INSULINA ................................65

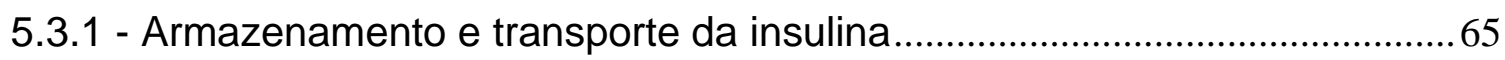

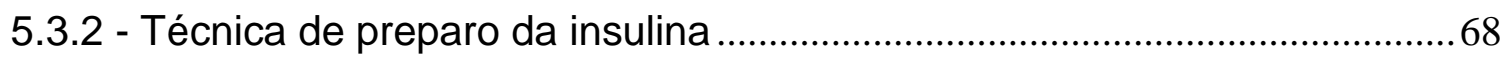

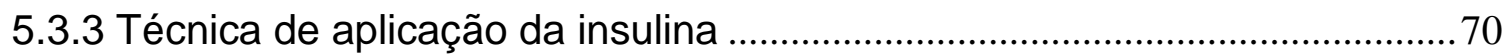

CAPÍTULO 6 - CONSIDERAÇÕES FINAIS ............................................................ 78

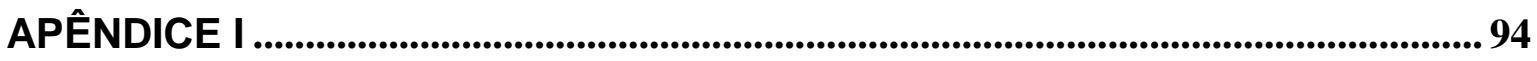

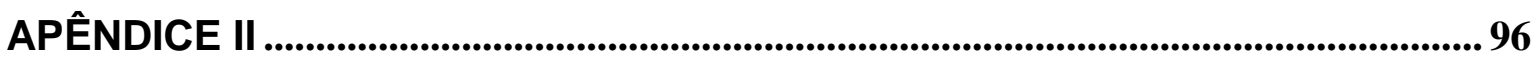

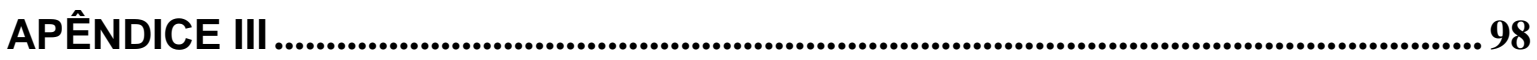

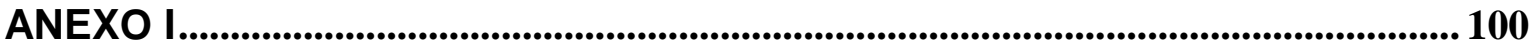




\section{LISTA DE FIGURAS}

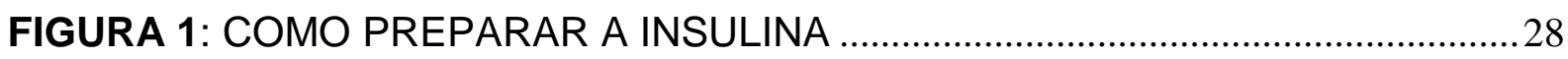

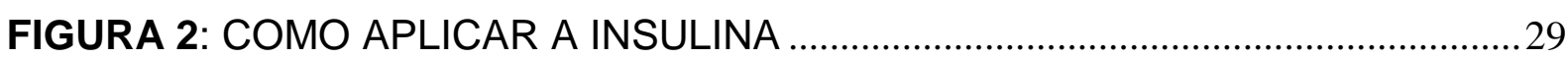

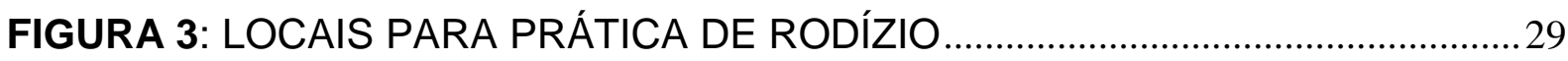

FIGURA 4: FLUXOGRAMA DE ATENDIMENTO AO PACIENTE DIABÉTICO...........33

FIGURA 5: AUTOGERENCIAMENTO DO CUIDADO NO MANEJO DA INSULINA.52 FIGURA 6: FATORES QUE DIFICULTAM O AUTOGERENCIAMENTO DO MANEJO DA INSULINA 


\section{ÍNDICE DE TABELAS}

Tabela 1 - Distribuição quanto ao número (N) e porcentagem (\%) dos entrevistados, segundo as variáveis sociodemográficas. Ceilândia, Brasília, 2016. 41

Tabela 2 - Distribuição quanto ao número $(\mathrm{N})$ e porcentagem (\%) dos entrevistados, segundo o tempo de diagnóstico, tempo de insulinoterapia e tipo de insulina utilizada. Ceilândia, Brasília, 2016 


\section{ÍNDICE DE QUADROS}

QUADRO 1: CONSERVAÇÃO DA INSULINA QUADRO 2: INDICAÇÕES E RECOMENDAÇÕES PARA O USO DAS AGULHAS 75 


\section{LISTA DE ABREVIATURAS}

ADA - American Diabetes Association

Aids - Síndrome da Imunodeficiência Adquirida

APS - Atenção Primária de Saúde

BHU - Basic Health Unit

CAPSAD - Centro de Atenção Psicossocial Álcool e Drogas

CONASS - Conselho Nacional de Secretários de Saúde

DF - Distrito Federal

DIMED - Diretoria da Divisão Nacional de Vigilância Sanitária de Medicamento

DM - Diabetes Mellitus

FEPECS - Fundação de Ensino e Pesquisa em Ciências da Saúde

GO - Goiás

GDF-Governo do Distrito Federal

IDF - Internacional Diabetes Federation

INCRA - Instituto Nacional de Colonização e Reforma Agrária

LADA - Diabetes Latente Autoimune do Adulto

MS - Ministério da Saúde

$\mathrm{NPH}$ - Neutral Protamine Hagedon

PDAD - Pesquisa Distrital por Amostra de Domicílios

PNH - Programa Nacional de Humanização

PUC Goiás - Pontifícia Universidade Católica de Goiás

QNQ - Quadra Norte Q

QNR - Quadra Norte R

RAS - Rede de Atenção à Saúde

SBD - Sociedade Brasileira de Diabetes

SUS - Sistema Único de Saúde

TCLE - Termo de Consentimento Livre e Esclarecido

UBS - Unidades Básicas de Saúde

UnB - Universidade de Brasília

UPA - Unidade de Pronto-Atendimento 
VIGITEL - Vigilância de Fatores de Risco e Proteção para Doenças Crônicas por Inquérito Telefônico 


\section{RESUMO}

TORQUATO, T. M. Significados da experiência da auto administração de insulina para pessoas que vivem com diabetes. 2016. 103f. Dissertação (Mestrado em Enfermagem) - Universidade de Brasília, Brasília, 2016.

O Diabetes Mellitus (DM) é uma síndrome endócrina, com causas multifatoriais, relacionada diretamente com problemas no pâncreas. O tratamento do DM inclui a adoção de hábitos de vida saudáveis como: a suspensão do tabagismo, prática de atividade física e reorganização dos hábitos alimentares, assim como uso de medicamentos orais, auto-monitoramento glicêmico e insulinoterapia. Sendo esta última, medida invasiva, permeada de dúvidas e resistências. Diante dessa situação, objetivamos, neste estudo, investigar a experiência da gestão do cuidado de pessoas que vivem com diabetes insulinotratadas. Desse modo, realizamos um estudo exploratório com abordagem qualitativa em uma Unidade Básica de Saúde (UBS), localizada em Regional Administrativa de Saúde do Distrito Federal. Participaram deste estudo dez usuários que vivem com DM e auto-administram insulina, e que concordaram em cooperar de modo voluntário. Para coleta de dados, utilizamos entrevista norteada por "Descreva-me a experiência de viver com diabetes e realizar o uso de insulina", como também de demonstração simulada da prática do manejo da insulina pelo participante. A partir da análise de conteúdo, emergiram duas categorias: a experiência dos usuários insulinotratados em viver com a sua condição crônica e administrar a insulina, e a gestão de cuidados no manejo da insulina. A maioria dos participantes era do sexo feminino, com idade entre 47 e 59 anos. Desse modo, os entrevistados revelaram que descobrir o diagnóstico de DM despertou emoções ligadas ao medo, ansiedade e depressão; que viver com o DM é uma experiência negativa, acreditam ter adquirido essa condição devido ao estilo de vida não saudável. A descoberta da necessidade do uso de insulina fez com que os usuários vivenciassem sentimentos de medo, raiva, angústia, ansiedade, susto e depressão; que a obrigatoriedade do uso contínuo da insulina incomoda os usuários; que, além de faltar fitas reagentes para realização do teste de glicemia periférica, também faltam medicamentos na UBS. Observamos, por meio das falas e das simulações realizadas, que os usuários apresentaram diferentes comportamentos relacionados ao armazenamento, transporte, preparo e aplicação da insulina. Dessa maneira, o significado do DM e o uso de insulina são circundados por sentimentos negativos e ações inadequadas, que precisam ser compreendidas pela equipe multidisciplinar responsável para assistência ao usuário.

Descritores: Diabetes Mellitus, Insulina, Atenção Primária a Saúde, Enfermagem. 


\begin{abstract}
TORQUATO, T. M. Meanings of the experience of self administration of insulin for people living with diabetes. 2016. 103p.Thesis (Master Degree in Nursing) Universidade de Brasilia, Brasilia, 2016.

Diabetes Mellitus (DM) is an endocrine syndrome, with multifactorial causes directly related to problems in the pancreas. Several studies have shown that diabetes treatment includes the adoption of healthy habits, such as: quitting smoking, physical activity practice and reorganization of eating habits, as well as the use of oral medications, insulin therapy and blood glucose self-monitoring. Thus, the more invasive treatment of diabetes is insulin therapy, which is permeated with doubts and resistance. Given this situation, this study aimed to investigate the experience of managing insulin-treated diabetics health care, by a regional health care institution in the Federal District of Brazil, called Basic Health Unit (BHU). An exploratory qualitative study was conducted, andten insulin-treated diabetics who self inject it, voluntarily, agreed to participate. For data collection, an interview guided by the statement: "Describe me the experience of living with diabetes and the use of insulin", as well as a simulated demonstration of its use by each of the participants were used. From the content analysis, two categories emerged: the experience of insulin-treated diabetics having to live with their chronic condition and the use of insulin; and the carewhen handling it.Most participants were female, aged 47-59 years old. Thus, respondents revealed that discovering the diagnosis of DM made emotions linked to fear, anxiety and depression to arouse; that living with DM is a negative experience; and that they believe they have acquired this condition due to unhealthy lifestyle. Being aware of their need for insulin made them experience feelings of fear, anger, distress, anxiety, and depression; the compulsory continuous insulin use bothers diabetics; and that in addition to the lack ofreagent strips to do the peripheral blood glucose test, there is also a lack of drugs at the BHU.So, it can be seen through the responses and simulations that the participants had different behaviors related to insulin storage, transportation, preparation and application. Thus, the DM meaning and the use of insulin is surrounded by negative feelings and inappropriate actions, that need to be understood by the multidisciplinary team responsible for diabetics' assistance.
\end{abstract}

Keywords: Diabetes Mellitus, Insulin, Primary Attention towards Health, Nursing. 


\section{RESUMEN}

Torquato, T. M. Significados de la experiencia de la autoadministración de insulina para personas con diabetes. 2016. 103H. Disertación (Maestría en Enfermería) - Universidad de Brasilia, Brasilia, 2016.

La diabetes mellitus (DM) es un síndrome endócrino con causas multifactoriales relacionadas directamente con los problemas en el páncreas. Varios estudios han demostrado que el tratamiento de DM incluye la adopción de hábitos de vida saludables como: dejar de fumar, la actividad física y la reorganización de los hábitos alimentarios, así como el uso de medicamentos orales, la insulinoterapia y el automonitoramiento glicémico. Así que, el tratamiento más invasivo de la diabetes es la terapia de insulina, impregnado con dudas y resistencia. Ante esta situación, se pretende en este estudio investigar la experiencia de la gestión del cuidado de las personas que viven con diabetes insulinotratados atendibles en la en la Superintendencia de Salud Oeste. De esta manera, realizamos un estudio con abordaje cualitativo exploratorio en una Unidad Básica de Salud (UBS), ubicada en la región administrativa de salud de Distrito Federal. Han participado de este estudio diez usuarios que viven con DM y se autoadministran insulina, y que han concordado en participar de modo voluntario. Para la recogida de datos, utilizamos la entrevista guiada por "Descríbame la experiencia de vivir con diabetes y realizar la aplicación de la insulina", así como la demostración simulada de la práctica de gestión de la insulina por parte del participante. A partir del análisis de contenido, emergieron dos categorías: la experiencia de los usuarios insulinotratados que viven con su enfermedad crónica y administrar la insulina, y la gestión de los cuidados en el manejo de la insulina. La mayoría de los participantes fueron mujeres, con edades entre 47-59 años. De este modo, los entrevistados revelaron que descubrir el diagnóstico de DM les despertó emociones relacionadas al miedo, ansiedad y depresión; que vivir con el DM es una experiencia negativa, creen haber adquirido esa condición debido al estilo de vida no saludable. El descubrimiento de la necesidad del uso de insulina hizo que los usuarios vivenciaran los sentimientos de miedo, ira, angustia, ansiedad y depresión, que la obrigatoriedad del uso contínuo de insulina les molesta, que además de faltar tiras reactivas para la prueba de glucosa en la sangre periférica también faltan medicinas en UBS. Se puede observar a través de los discursos y las simulaciones que los usuarios presentaron distintos comportamientos relacionados con el almacenamiento, el transporte, la preparación y la aplicación de la insulina. Por lo tanto, el significado de la DM y el uso de la insulina están rodeados de sentimientos negativos y acciones inapropiadas que necesitan ser entendidos por el equipo multidisciplinario responsable de la asistencia al usuario.

Palabras clave: Diabetes mellitus, Insulina, Atención Primaria a la Salud, Enfermería. 


\section{APRESENTAÇÃO}

Minha trajetória e aproximação ao tema Diabetes Mellitus (DM) iniciou-se na graduação em 2008, de forma espontânea e voluntária, no estágio não curricular no Centro de Referência de Hipertensão Arterial e Diabetes Mellitus, no município de Rio Verde - GO, e lá permaneci por dois anos.

Durante esse tempo, desenvolvemos dois estudos, um deles o artigo intitulado "Perfil Epidemiológico de Clientes com Hipertensão Arterial Sistêmica e Diabetes Mellitus: evidências para o ensino do autocuidado", publicado na Revista Objetiva, do Instituto de Ensino Superior de Rio Verde (FERREIRA et al., 2010); e o outro foi a elaboração do trabalho de conclusão de curso: "Conhecimento dos clientes diabéticos em relação aos cuidados com a insulinoterapia" (TORQUATO, 2010).

Logo após a graduação, iniciei a especialização em Urgência e Emergência em que escrevemos o artigo: "Atuação do Enfermeiro no Serviço de Emergência na Assistência ao Cliente com Cetoacidose Diabética: uma revisão bibliográfica" com a orientação da professora Doutora Marislei Espíndula Brasileiro, publicado e apresentado na 7.. Mostra de Produção Científica da Pós-Graduação Lato Sensu, da Pontifícia Universidade Católica de Goiás - PUC (TORQUATO, 2012).

Nesse mesmo período, comecei a trajetória como docente e orientei dois trabalhos de conclusão de curso com o DM como tema de estudo, o primeiro: "Análise do Estado Psicológico de Adolescentes com Diabetes Juvenil"; e o segundo: "Diabetes Latente Autoimune do Adulto (LADA): uma revisão bibliográfica".

Essas experiências aproximaram-me da temática, na qual tenho trabalhado até o presente momento, oportunidades para aprofundar meu conhecimento acerca do DM, como também conhecer as facilidades e barreiras relacionadas à adesão do usuário com DM ao tratamento com a insulina.

Esses conhecimentos adquiridos ao longo dessa trajetória acadêmica/profissional possibilitaram a inclusão do DM mais uma vez como configuração do tema de investigação no mestrado. Mas dessa vez foi diferente, aproximamos da pesquisa qualitativa para descrever quais experiências são vivenciadas pelos diabéticos em relação à sua condição crônica e ao uso de insulina.

O interesse por essa temática se deu pelo fato de querermos compreender 0 viver do adulto com diabetes e a sua gestão ao fazer o uso de insulina, ponto 
fundamental para que se preste assistência eficaz e se propicie melhor qualidade de vida ao mesmo.

Outro ponto considerado foi a percepção que os profissionais de saúde prestam assistência voltada à doença, particularmente ao controle glicêmico, numa clara demonstração que o cuidado ainda é mais voltado para patologia do que para o ser humano que a possui.

Nesse sentido, este estudo tem como intuito compreender o processo do viver com DM, sob a ótica de quem a experimenta em seu cotidiano, e como eles enfrentam as adversidades advindas do processo de adoecer e de seu tratamento.

Diante do exposto, apresentamos a pesquisa desenvolvida, que está organizada em seis capítulos, nos quais procuramos discorrer sobre a autogestão do cuidado relacionado ao DM e ao uso de insulina de forma a aprofundar a discussão segundo referenciais atualizados, buscando evidenciar possibilidades de melhorar a assistência oferecida aos usuários insulinodependentes.

No Capítulo 01, delimitamos nosso objeto de estudo relatando publicações nessa temática nos últimos anos e levantamos breve panorama da autogestão dos usuários em relação ao uso de insulina.

O Capítulo 02 trata da revisão da literatura, constituído de elementos da literatura que trazem esclarecimentos e sustentação para a análise do material coletado na pesquisa. Consiste na delimitação conceitual da experiência em possuir DM e utilizar insulina.

O Capítulo 03 é constituído pelo caminho metodológico, sob o qual a investigação foi conduzida, com o contexto detalhado do nosso campo de estudo, do trabalho de campo, com a coleta dos dados por meio de entrevistas e simulações. Relata também, o cumprimento dos requisitos éticos para a execução da pesquisa.

No Capítulo 04 encontra-se os resultados oriundos do material coletado que possibilitou a construção de duas categorias temáticas: A experiência dos insulinotratados em viver com a sua condição crônica e administrar a insulina; e a gestão do cuidado no manejo da insulina. Já no capítulo 05 encontra-se a discussão dos resultados levantados.

Encerrando a pesquisa, tecemos nossas considerações finais (capítulo 6) que contém nossas impressões e sentimentos por termos participado da pesquisa, suas contribuições para a Enfermagem, a comunidade de estudos e incentivos de políticas públicas nessa temática. 


\section{CAPÍTULO 1 - DELIMITANDO O OBJETO E OBJETIVO DO ESTUDO}

O Diabetes Mellitus (DM) é uma síndrome endócrina, com causas multifatoriais, relacionada diretamente a alterações no metabolismo de insulina, como quantidade insuficiente, não produção ou impossibilidade desse hormônio exercer sua função com êxito. Geralmente, essa deficiência pode ocasionar hiperglicemia constante e outras complicações, como lesões no coração, olhos, nervos, rins e nos membros periféricos (PEREIRA et al., 2012; BRASIL, 2013).

O DM é um problema de saúde pública, devido à sua elevada morbimortalidade em todo o mundo; essa síndrome é considerada uma condição sensível à Atenção Primária de Saúde (APS), visto que estudos demonstraram que o manejo adequado e o acompanhamento do diabético na Atenção Básica evitam futuras complicações como cegueira, amputações, problemas circulatório e cardíacos (ALFRADIQUE, 2009; PEREIRA et al., 2012).

Em 2011, a pesquisa realizada pela Vigilância de Fatores de Risco e Proteção para Doenças Crônicas por Inquérito Telefônico (VIGITEL), nas 26 capitais brasileiras e no Distrito Federal,constatou que $5,6 \%$ da população brasileira referem ter a doença e que as ocorrências são mais comuns em pessoas com baixa escolaridade e aumenta de acordo com a idade (VIGITEL, 2011).

Dados de 2013, da International Diabetes Federation (IDF), mostram que o Brasil ocupa a quarta posição entre os países com maior prevalência de DM no mundo, obtendo um total de 13,4 milhões de portadores na fase etária de 20 a 79 anos.

Em decorrência do aumento de casos de indivíduos com DM, tornou-se necessário desenvolver estratégias para alcançar o controle metabólico e prevenir futuras complicações. Dentre as alternativas terapêuticas, a insulinoterapia constitui-se em opção eficiente, no sentido de se aproximar do perfil fisiológico da secreção pancreática de insulina no usuário (BATISTA et al., 2013).

Vale ressaltar que a insulina somente é indicada quando os níveis de glicose plasmática estiverem maiores de $300 \mathrm{mg} / \mathrm{dl}$, na primeira avaliação ou no momento do diagnóstico, principalmente se acompanhado de perda ponderal, cetonúria e cetonemia. Esse hormônio também é utilizado caso o controle metabólico, após três a 
seis meses, não seja alcançado com medicamentos orais, como o uso de metformina em associação da sulfonilureia, por exemplo (BRASIL, 2013).

No entanto, o tratamento do DM não se limita somente à insulinoterapia; inclui modificações do estilo de vida, como a suspensão do tabagismo, aumento da atividade física e reorganização dos hábitos alimentares, assim como o uso de medicamentos orais e injetáveis. Para tanto, a participação de prática de educação em saúde pode auxiliar na adoção de hábitos de vida saudáveis (OLIVEIRA; ZANETTI, 2011).

Pereira et al. (2012) reafirmam que o desenvolvimento das ações relacionadas a modificações do estilo de vida tem que ter como apoio alternativo a educação em saúde, por ser estratégia que propicia informações aos portadores da doença, no sentido de incentivar ação participativa em seu tratamento, e, consequentemente, promover a gestão do cuidado (PEREIRA et al., 2012).

Um dos principais problemas da gestão de cuidado no DM é o abandono ou o uso incorreto dos tratamentos prescritos pelos profissionais de saúde, principalmente a insulina. A falta de adesão não está somente relacionada a tomar ou não tomar remédios, mas como o usuário gere seu tratamento, ou seja, qual é seu comportamento em relação à dosagem, horário, frequência e duração do tratamento instituído (LACERDA, 2010).

Vários estudos (TORRES et al., 2013; GRILLO et al., 2013; TORRES, PEREIRA, ALEXANDRE, 2011) evidenciaram que pessoas com DM apresentaram défice de gestão de cuidado relacionados à dieta, à atividade física, ao sono, repouso, a interação social e principalmente à prática de insulinoterapia, associados à não incorporação do tratamento e às condutas inerentes ao estilo de vida saudável por esses indivíduos. Tais comportamentos são influenciados por fatores como a escolaridade, o nível socioeconômico, a idade, os medos, a ansiedade, indisponibilidade de tempo, a indisposição para realizar atividades físicas e a falta de apoio familiar (TORRES, PEREIRA, ALEXANDRE, 2011).

Torres et al (2010) defendem que a gestão do cuidado deve ser centrada no conhecimento e na atitude do usuário frente à doença, visando a adesão às práticas do autocuidado e potencializando os recursos pessoais para o enfrentamento da doença.

Já Costa, Zago e Medeiros (2009, p. 633) ressaltam que "a adesão consiste na busca da aceitação do diagnóstico, da mudança que ocorre no corpo, da importância do segredo do diagnóstico". Eles afirmam ainda que a aceitação do diagnóstico e a adesão ao tratamento acontecem em um tempo diferenciado para cada usuário. 
Vale ressaltar ainda que o DM ocasiona alterações fisiológicas importantes no organismo do usuário, acarretando mudanças significativas na relação que o usuário diabético estabelece com seu próprio corpo, outras pessoas e o mundo que o cerca, obrigando-o, muitas vezes, a vivenciar experiências diversas ao longo de sua trajetória de vida (BATISTA; LUZ, 2012).

Outra constatação é que, dentre a variedade de estudos que abordam o DM, poucos são aqueles que buscam uma compreensão da experiência de vida dos usuários em viver com sua condição crônica e utilizar a insulina.

Diante do exposto, o estudo da experiência do usuário em viver com DM e utilizar insulina se justifica pela imprescindibilidade de compreender as reais necessidades dos usuários e fundamentar propostas de intervenção na atenção primária a esse público. Estudos dessa natureza investigam como as pessoas constroem seus caminhos ao lidar com exigências e consequências da cronicidade da doença (REZENDE, 2010; FRAGOSO et al., 2010).

Este estudo de compreensão da experiência possui o intuito de auxiliar a reorganização da atenção ao diabético em nível de atenção primária à saúde, com vistas a propor intervenções eficazes e dirigidas de forma a minimizar a morbimortalidade, oferecendo melhor qualidade de vida aos usuários.

Acreditamos que o desenvolvimento desse estudo é de suma importância, pois ele poderá servir de subsídio para o gerenciamento do cuidado, na elaboração de planos de cuidados específicos voltados às necessidades do grupo de estudo, facilitando o atendimento em saúde com a orientação de pessoas que fazem uso de insulinoterapia e, consequentemente, diminuindo as complicações decorrentes das experiências estudadas.

Consideramos que para a equipe de saúde realizar atendimento de qualidade aos usuários insulinodependentes é necessário reconhecer, compreender e valorizar o significado das experiências da gestão do cuidado de pessoas que vivem com diabetes e insulinotratadas. Para tanto, faz-se necessária uma aproximação e vivência junto a esses usuários de forma que possam nos auxiliar a desvendar os questionamentos dessa investigação: o que significa a gestão do cuidado de pessoas que vivem com DM? Como esses usuários lidam com a insulinoterapia em seu cotidiano? 
Suas vozes a esses questionamentos, juntamente com o conhecimento científico, certamente possibilitarão o estabelecimento de estratégias para um atendimento de qualidade, humanizado, resolutivo e combatível ao usuário com DM em insulinoterapia. Contudo, pretendemos, com essa pesquisa, atingir os seguintes objetivos:

Geral:

> Compreender os significados da experiência da gestão do cuidado de pessoas que vivem com diabetes e insulinotratadas.

Específicos:

> Conhecer o perfil de pessoas que vivem com diabetes e insulinotratadas,.

$>$ Compreender a experiência de administração de insulina para pessoas que vivem com diabetes.

> Identificar fatores que dificultem a prática segura da insulinoterapia.

> Descrever a prática correta de preparo, administração, armazenamento e conservação da insulina.

Assim, acreditamos que os resultados deste estudo contribuirão para melhoria da assistência à saúde dos usuários diabéticos insulinodependentes na medida em que oferecem subsídios à atuação do Enfermeiro, bem como de outros profissionais da área de saúde, no estabelecimento de ações coerentes e resolutivas para o atendimento desse grupo e também na construção de políticas públicas direcionadas aos usuários diabéticos em uso de insulina. 


\section{CAPÍTULO 2 - REVISÃO DA LITERATURA}

Esta pesquisa inclui os temas: Diabetes Mellitus, experiência, insulinoterapia e gestão do cuidado. Assim, neste capítulo ressaltaremos de modo sucinto as experiências vivenciadas por usuários relacionadas a sua condição crônica e ao uso de insulina, também descreveremos a importância do próprio usuário realizar a gestão do seu regime terapêutico e os pressupostos do estudo.

\section{1 - A EXPERIÊNCIA EM POSSUIR DIABETES E UTILIZAR INSULINA}

O DM é um problema de importância crescente em saúde pública, do ponto de vista emocional, econômico e social para as instituições e as famílias que vivem com essa síndrome, visto que sua incidência e prevalência estão aumentando, alcançando proporções epidêmicas (SBD, 2015; REZENDE et al., 2014).

De acordo com Rezende et al. (2014, p.73):

O Diabetes Mellitus é uma síndrome complexa e heterogênea, de origem multifatorial, caracterizada por desordens metabólicas, em que a capacidade de metabolização de glicídios se encontra prejudicada por distúrbios na insulina (incapacidade de secreção, ação diminuída sobre os tecidos-alvos ou ambos) ocasionando alterações na perfusão tecidual e na permeabilidade microvascular, diminuição do metabolismo protéico, aumento no metabolismo lipídico, deficiência na migração dos neutrófilos, comprometimento da fagocitose e exagerada resposta inflamatória aos produtos microbianos [...].

Assim, o DM ocasiona alterações fisiológicas importantes no organismo, obrigando os usuários muitas vezes a vivenciar experiências diversas ao longo de sua trajetória de vida, que podem dificultar a sua aceitação da doença e a adoção da gestão do cuidado (BATISTA; LUZ, 2012).

Para Bondía (2002), "a experiência é o que nos passa, o que nos acontece, o que nos toca". Já Michaelis (2009) define experiência como "conhecimento adquirido graças aos dados fornecidos pela própria vida". A importância de estudar a experiência dos usuários acometidos por DM em uso de insulina é compreender como o usuário lida com a sua condição crônica e o uso de insulina, e saber identificar qual sentimento ele vivencia. Isso é primordial para que a equipe de saúde possa propor intervenções que sejam realmente eficazes no cuidado, pois estudos relacionam as experiências 
vivenciadas pelos portadores de diabetes como algo negativo e estressor, que influenciam negativamente a adesão à gestão do cuidado (PÉRES et al., 2007; DAMIÃO et al., 2009; CHAVES; TEIXEIRA; SILVA, 2013).

Faria e Bellato (2010) descrevem que o DM é visto pelo indivíduo diabético como uma experiência que ameaça a sua vida, pois o diagnóstico da doença pode desencadear sentimentos como impotência, desesperança, desvalorização, temor, apreensão e o medo da morte.

Soares, Araújo e Oliveira (2014) afirmam que o DM modifica profundamente a vida dessas pessoas, pois, no decorrer do tratamento, a pessoa vivencia sentimentos como angústia e desespero frente à percepção do pouco controle acerca de sua vida, dificultando muitas vezes a aceitação de sua condição crônica de saúde.

Ainda segundo esses autores, o automanejo do DM se faz necessário para o controle da síndrome hiperglicêmica; porém, para melhorar o prognóstico da doença, mudanças no estilo de vida são necessárias.

Já Moreira et al. (2008) destacam que o sentimento mais vivenciado pelos usuários com DM é o de culpa, o qual é amenizado à medida que os usuários vão aprendendo a conviver com a doença.

O enfrentamento do DM impacta tanto na vida do usuário, como na da sua família e até mesmo na comunidade em que vive, pois vários relatam vivenciar as experiências de isolamento social, empobrecimento da autoimagem, dificuldades na promoção do autocuidado e conflitos gerados pela dependência de cuidados de outras pessoas e pelo uso de medicamentos (DAMIÃO et al., 2009; PÉRES et al., 2007).

Correr et al. (2013) afirmam que a descoberta do DM foi algo marcante na vida dos usuários, os quais demonstraram sonhos, otimismo, preocupação para melhorar o seu bem-estar e um desejo enorme de eliminar a insulinodependência de suas vidas.

Vale ressaltar que o uso de insulina faz-se necessário por constituir-se uma opção terapêutica eficiente, frente à deficiência do pâncreas em produzir adequados níveis dessa substância. O seu objetivo é promover o controle metabólico, permitindo o crescimento e desenvolvimento adequado, gerando o bem-estar físico, psíquico e social do usuário (KATZUNG, 2003).

Péres et al. (2007) ressaltam, no entanto, que a insulinodependência gera sentimentos como ódio, pavor e mau humor, e que vários usuários têm dificuldades em aceitar o uso desse hormônio, visto que a sua administração causa agressão ao corpo, impõe limites de atividades relacionadas ao trabalho e lazer, causa dependência 
química, traz preocupações com horário e precisão das doses e provoca discriminações.

Ferreira et al. (2013) afirmam que as reações emocionais surgem a partir da necessidade de cuidados, como o uso de insulina, pois geralmente os usuários se sentem desanimados, visto que o ato de realizar diariamente o controle da glicemia e a aplicação de insulina não representa a cura da doença. Esses autores ressaltam também que muitos usuários não aceitam a obrigatoriedade do uso de insulina cotidianamente, pois ela representa uma forma de tratamento incômodo, de caráter restritivo.

Os usuários estudados por Chaves, Teixeira e Silva (2013) relatam também que viver com diabetes é algo negativo e que muitos são obrigados a promoverem o seu autocuidado, como autoaplicar a insulina, devido ao medo de perder sua saúde. Eles expressam claramente seu temor por uma mutilação, cegueira, pela possibilidade de perder sua capacidade de ir e vir e de cuidar de si mesmo.

Assim, 0 ato de utilizar a insulina intensifica os sentimentos vivenciados pelos usuários com DM ao descobrir o diagnóstico de sua condição crônica. Esses sentimentos são resultantes das limitações que a doença e seu tratamento impõem como controle diário da glicemia, prática de exercício físico, realização de exames laboratoriais, dieta, e uso rotineiro de medicações (FARIA; BELLATO, 2010; CORRER et al.,2013).

Silva, Santana e Palmeira (2013) revelam que o ato de usar insulina tem diferentes significados, que vão desde os benefícios da terapêutica até uma concepção negativa que envolve sentimento de medo e incômodo; porém, pode proporcionar bons níveis glicêmicos, aumentar a expectativa e a qualidade de vida dos usuários.

Para obter os benefícios da terapêutica é necessária uma boa adesão tanto ao tratamento insulínico quanto à adoção de medidas relacionadas à mudança dos hábitos de vida do usuário; porém, isso só é alcançado quando o usuário percebe que o uso da insulina leva à obtenção do bem-estar (SBD, 2015).

Dessa forma, Filho, Rodrigues e Santos (2008) revelam que o DM e seu tratamento causam impacto negativo na vida biopsicossocial do usuário; assim, faz-se necessário um olhar macro por parte dos profissionais de saúde, com a finalidade de identificar grupos de pessoas com baixa aceitação terapêutica e, consequentemente, mediar relações entre reações emocionais e ações de gestão do cuidado, visando melhorar a qualidade de vida dos usuários com DM em uso de insulina. 


\section{2 - GESTÃO DO REGIME TERAPÊUTICO}

Por se tratar de uma síndrome crônica, o tratamento do DM inclui diversas estratégias como a educação, modificação do estilo de vida e, se necessário, o uso de medicamentos. Das medicações prescritas para o controle do DM, a insulina é mais temida também por parte dos profissionais de saúde, que retardam sua prescrição, como pelos usuários, que possuem medo do uso rotineiro de injeções subcutâneas (BONIFÁCIO et al., 2008).

O objetivo da administração de insulina é aproximar o sujeito usuário do perfil fisiológico da secreção normal de insulina. Dessa forma, as múltiplas doses de insulinas são necessárias a fim de controlar a taxa glicêmica do usuário (SBD, 2015).

Porém, para um controle glicêmico adequado, faz-se necessário reestruturar os níveis de cuidados por meio da gestão do regime terapêutico. Para Bastos (2012, p.307), a gestão de regime terapêutico:

é um conceito mais global, que engloba a adesão, mas que vai além da volição e inclui, entre outros aspectos, a capacidade de decisão sobre a mudança de um comportamento face à modificação do status de um sintoma ou face a uma nova circunstância, incorporando, por isso, o autoconhecimento e o conhecimento técnico necessário para interpretar e agir em conformidade.

Rodrigues (2014) reforça a ideia que a gestão do regime terapêutico leva em consideração a atitude das pessoas face à doença e à sua relação com o sistema de saúde.

Já para Pires e Gottems (2009) a gestão do cuidado é a forma como o "cuidar se revela e se organiza na interação propiciada entre sujeitos, podendo gerar interações e subversões potencialmente emancipatórias ou restritivas das múltiplas liberdades humanas".

Assim, entendemos que a gestão do regime terapêutico converge com 0 conceito de gestão do cuidado, visto que ambos termos possuem como foco à atenção voltada às necessidades dos usuários com a capacidade de identificar recursos, falhas e dificuldades encontradas durante todo o processo terapêutico ofertado pelo sistema de saúde. Dessa forma, nesse estudo o termo gestão do regime terapêutico será utilizado como sinônimo da gestão do cuidado.

Diógenes et al. (2012) ressaltam que o próprio usuário com DM deve realizar a gestão do seu regime terapêutico, autoadministrando a insulina prescrita, uma vez que isso traz autonomia ao usuário, porém é também aconselhável que pelo menos um 
membro da família deva aprender a técnica de administração de insulina para agir nas situações de emergências.

Dessa forma, a técnica de preparo e aplicação da insulina, envolve etapas consecutivas, quando seguidas corretamente, contribuem com a prática segura para o alcance dos objetivos do tratamento (BRASIL, 2006). Assim, as etapas estão descritas detalhadamente nas Figuras 1, 2 e 3:

FIGURA 1: COMO PREPARAR A INSULINA

\section{Como Preparar a Insulina}

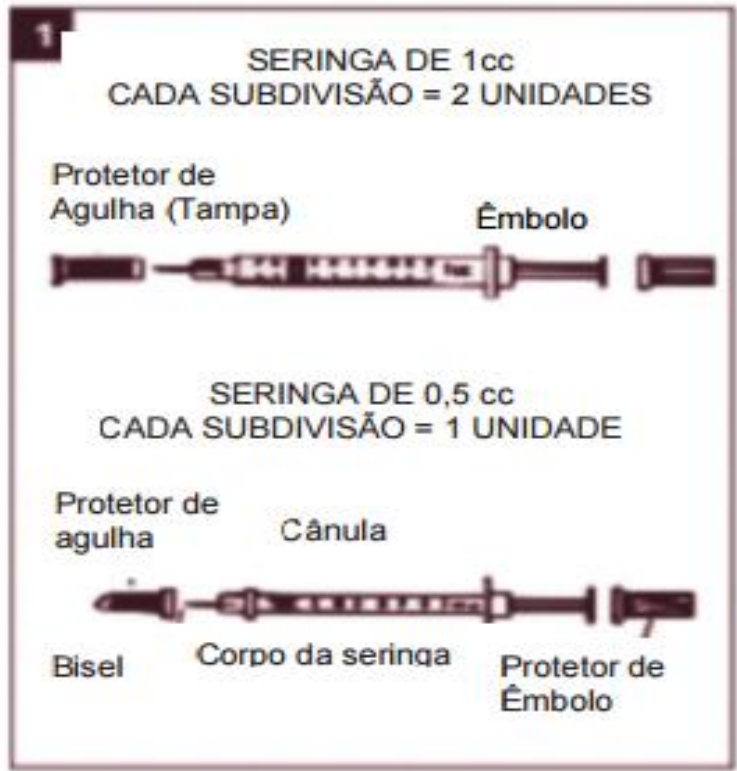

2 Lavar bem as mãos com água e

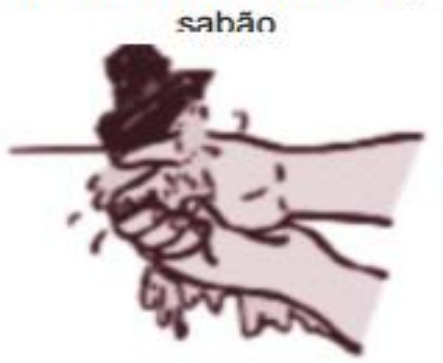

\section{3}

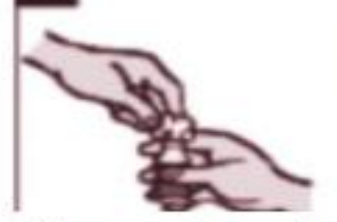

Limpar a tampa do frasco usando algodāo com álcool
Rolar o frasco entre as mãos para misturar a insulina. Năo agitar o frasco.

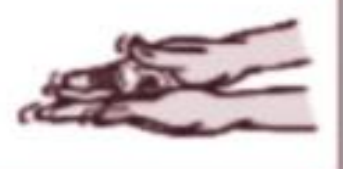

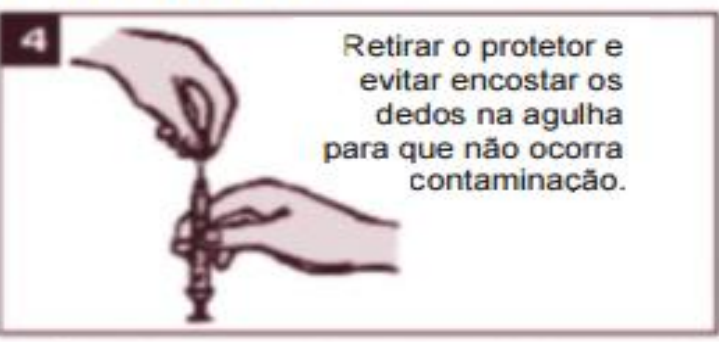

5

Puxar o êmbolo da seringa até a marca da quantidade de insulina que você usa.

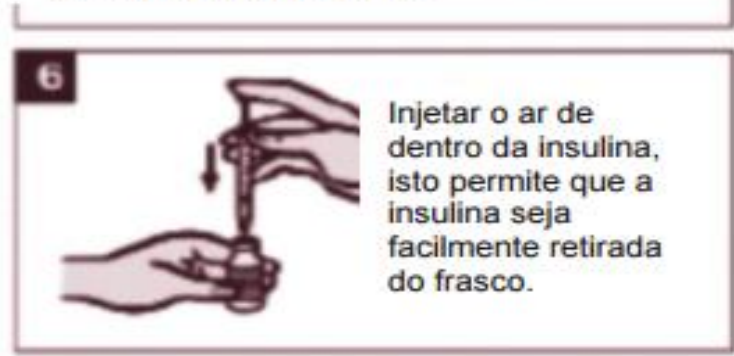

7

Virar o frasco e a seringa para baixo. Puxar o êmbolo lentamente, para aspirar a insulina para dentro da seringa.

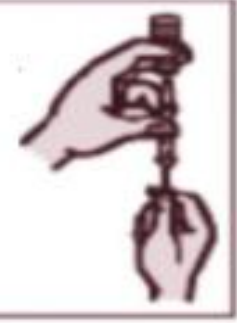

8 Verificar se existem bolhas de ar. Para tirá-las, bater com o dedo na

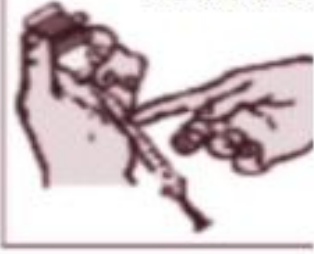
parte da seringa onde elas estão ou injetar a insulina de volta para o frasco. Em seguida, retirar a dose de insulina que vocé vai usar. 
FIGURA 2: COMO APLICAR A INSULINA

\section{COMO APLICAR A INSULINA}

1

Escolher o local para aplicar a insulina. Limpar a pele usando algodão com álcool e deixar secar. Manter uma distância de mais ou menos $2 \mathrm{~cm}$ do local onde você tomou $\mathrm{a}$ injeção anterior, se a área do corpo for a mesma

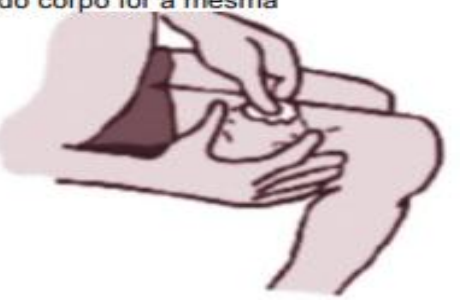

Fazer uma prega na pele onde você vai aplicar a insulina. Pegar na seringa como se fosse um lapis. Introduzir a agulha na pele. num ângulo de $90^{\circ}$, soltar a prega cutânea. Obs.: em pessoas muito magras ou crianças menores, a injeçăo poderá ser feita num angulo de $45^{\circ}$ para evitar que seja aplicada no músculo.

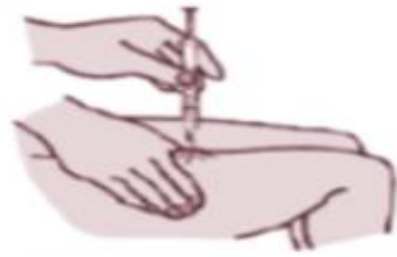

Ao iniciar a aplicaçăo da insulina, se or encontrada a presenca de sangue orientaçōes:

1) Sangue em pequena 1) quantidade: continuar a aplicação 2) Sangue em grande quantidade: parar a aplicação. Jogue fora a seringa com a insulina e prepare outra dose.

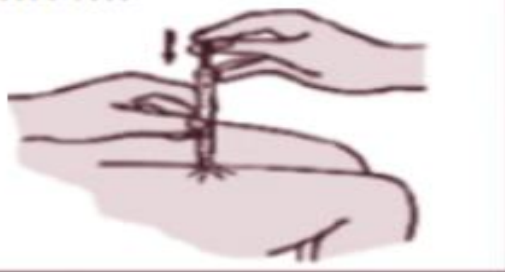

Injetar insulina, empurrando o êmbolo até o final. Retirar a seringa e fazer uma leve pressão no local, usando o algodão com álcool

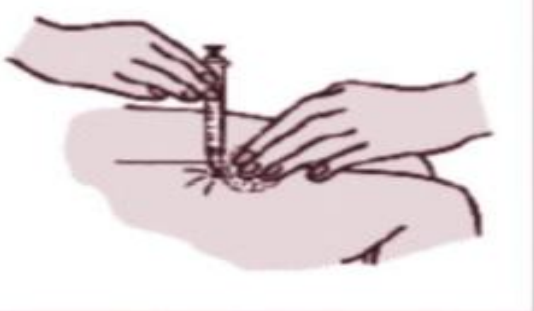

FONTE: BRASIL, 2006

FIGURA 3: LOCAIS PARA PRÁTICA DE RODÍZIO

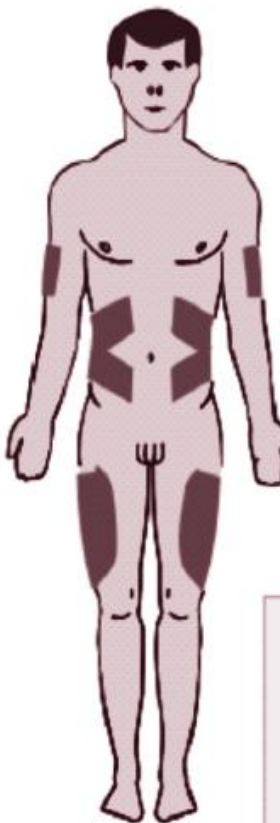

FRENTE
BRAÇOS

(parte externa e superior)

COXAS

(parte anterior e lateral)

REGIÃO ABDOMINAL

REGIÃO GLÚTEA
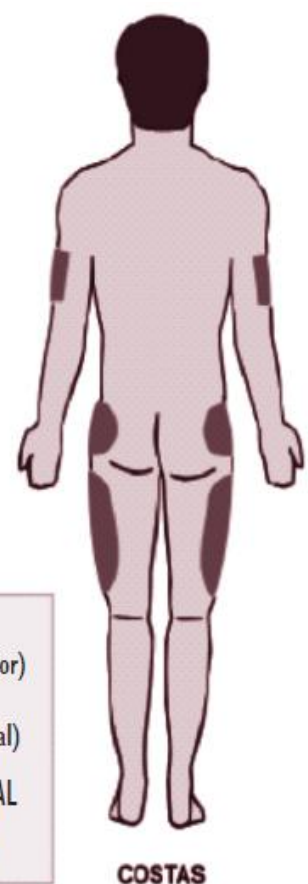

FONTE: BRASIL, 2006 
A técnica de preparo e administração da insulina requer vários cuidados, conhecimentos e habilidades técnicas. Para que ocorra, fazem-se necessários tempo, prática, educação continuada para os usuários e elaborar estratégias para promover o conhecimento e o desenvolvimento de habilidades para a promoção da gestão do cuidado, considerando as limitações cognitivas, econômicas e sociais de cada usuário (STACCIARINI; CAETANO; PACE, 2011).

Contudo, o que se observa nos estudos encontrados (GAERTNER et al., 2014; BATISTA et al., 2013; DIÓGENES et al., 2012) é que os usuários que autoadministram a insulina não possuem conhecimentos e nem habilidades para realizarem essa prática de forma segura.

Gaertner et al. (2014) revelam que as principais falhas no tratamento com insulina são: a reutilização do conjunto seringa/agulha além do preconizado, a realização de assepsia da agulha utilizando algodão com álcool e o desconhecimento relacionado ao armazenamento da insulina.

Batista et al. (2013) identificaram que as pessoas que utilizam insulina apresentam erros em diversas etapas do processo de aplicação de insulina. Para esses autores, o empoderamento dos usuários foi aprimorado após a intervenção de profissionais de saúde e de outros usuários, utilizando a metodologia da educação em saúde em forma de grupo, para a troca de experiências e incorporação de novos conhecimentos acerca da patologia.

Diógenes et al. (2012) também demonstraram em seu estudo que os usuários apresentaram défice de conhecimento em relação à prática da insulinoterapia, sendo que relacionaram esse fato com o nível de escolaridade dos participantes, pois quanto menor são os anos de estudos, maiores são as chances para os usuários não autoadministrarem a insulina adequadamente.

Os conjuntos de ações inadequadas descritas anteriormente para o manejo da insulina devem ser trabalhados na APS, pois as políticas de saúde votadas à condição crônica, como o DM, são elaboradas pelo MS, e possuem como objetivo fornecer informações e direcionamentos aos profissionais, para que possam conduzir suas ações de modo a alcançar o controle metabólico, a partir da compreensão da doença e do manejo do tratamento (OLIVEIRA; ZANETTI, 2011).

Moreira et al. (2008) ressaltam a desobediência e resistência do usuário, o despreparo da família para realizar essa técnica, a dependência de outras pessoas para administrarem a insulina e a realização incorreta do procedimento. 
Entretanto, além da gestão do cuidado sobre a técnica correta do manuseio da insulina por parte do usuário, faz-se necessária a atuação efetiva dos gestores e dos profissionais de saúde juntamente com a participação dos usuários com diabetes, pactuando corresponsabilidades e compromisso para a gestão do seu cuidado, com o intuito de manter a sua qualidade de vida (TAVARES et al., 2011).

Stacciarini, Pace e Haas (2009) reforçam que os profissionais das Unidades Básicas de Saúde (UBS) devem atuar precocemente nas dificuldades levantadas para a realização da gestão do cuidado, como também planejar a aquisição de insumos de acordo com as características da população atendida. Apesar do conhecimento técnico-científico dos enfermeiros em relação à administração de medicamentos, esses profissionais ainda possuem uma participação menos expressiva na orientação do processo de administração da insulina no domicílio, quando comparados com a atuação dos médicos (STACCIARINI, PACE, HAAS; 2009).

Vale ressaltar que a importância da participação de outras categorias profissionais atuantes na atenção primária para garantir educação em saúde, considerando os aspectos psicológicos, culturais, sociais, interpessoais e as necessidades psicológicas da pessoa diabética, minimizariam os problemas de gestão dessa terapêutica. A atuação de uma equipe multiprofissional é concebida como recurso para a articulação dos saberes, diante da complexidade que o DM impõe para o usuário que o possui (SOARES; ARAÚJO; OLIVEIRA, 2014).

Uma pesquisa realizada nas UBS de um município de pequeno porte do interior do estado de São Paulo (FERRAZ et al., 2015) avaliou o sistema de gerenciamento de usuários com DM, sob a perspectiva do olhar do profissional enfermeiro, constatando que as principais dificuldades encontradas para gerir esse sistema se resumem em dois polos principais: um ligado aos fatores socioeconômicos e outro ligado aos fatores administrativos do sistema de saúde.

Os fatores ligados às condições socioeconômicas interferem na adesão adequada de uma dieta balanceada e na compreensão da doença, demonstrando que existe uma relação entre a dificuldade de adesão ao tratamento e a vulnerabilidade social do usuário. Já os fatores administrativos do sistema de saúde estão ligados ao número insuficiente de profissionais, baixa qualificação, ausência de equipe multidisciplinar, deficiência nos encaminhamentos para especialistas como endocrinologista e oftalmologista e baixa resolubilidade dos problemas (FERRAZ et al., 2015). 
Os fatores administrativos do sistema de saúde também foram abordados por Maggini (2009), que ressalta que a atuação dos gestores dos serviços de saúde deve estar voltada a articular condições para que o treinamento dos profissionais aconteça, com a finalidade de colocar em prática as recomendações estabelecidas pelas políticas nacionais de saúde. Um profissional desatualizado atua de modo limitado, se restringindo a realizar orientações somente sobre restrições e proibições, intensificando ainda mais o sentimento de falta de liberdade, angústia, tristeza e frustrações vivenciadas pelos usuários (FERRAZ et al., 2015).

Cabe também aos gestores fornecerem infraestrutura e materiais de consumo adequados para o desenvolvimento do processo de trabalho dos profissionais, respeitando as boas práticas clínicas e fornecendo uma terapêutica individualizada (ASSIS; SIMÕES; CAVALCANTI, 2012).

Já para Lorenzetti et al., (2014) a missão dos gestores é responder às expectativas e necessidades de saúde da população, buscando superar a fragmentação dos serviços de saúde para maior eficiência e melhor atendimento aos usuários. Ainda de acordo com os autores, tais serviços devem ser organizados em rede de atenção à saúde (RAS), com o intuito de prestá-los de forma equitativa e integral a uma população definida.

A RAS foi lançada pelo MS com a proposta de mudanças nos processos de trabalho em saúde. Considerando os componentes do processo de trabalho como agentes (profissionais de saúde, gestores, usuários), objeto (necessidades de saúde), e instrumentos (tecnologia materiais e não materiais). Dessa forma, a gestão do cuidado passa a ser reorganizada por meio da aplicação do gerenciamento do cuidado como o principal instrumento de trabalho, em que se pode prestar a assistência aos usuários, observar e atender as necessidades de saúde, adquirir e organizar os instrumentais e treinar os agentes conforme as suas necessidades (BRASIL, 2013).

Visando a elaboração do processo de trabalho, o Conselho Nacional de Secretários de Saúde (CONASS, 2015) reforça que o atendimento ao usuário diabético também deve ser organizado em redes, conforme demonstra o fluxograma na Figura 4: 
FIGURA 4: FLUXOGRAMA DE ATENDIMENTO AO PACIENTE DIABÉTICO

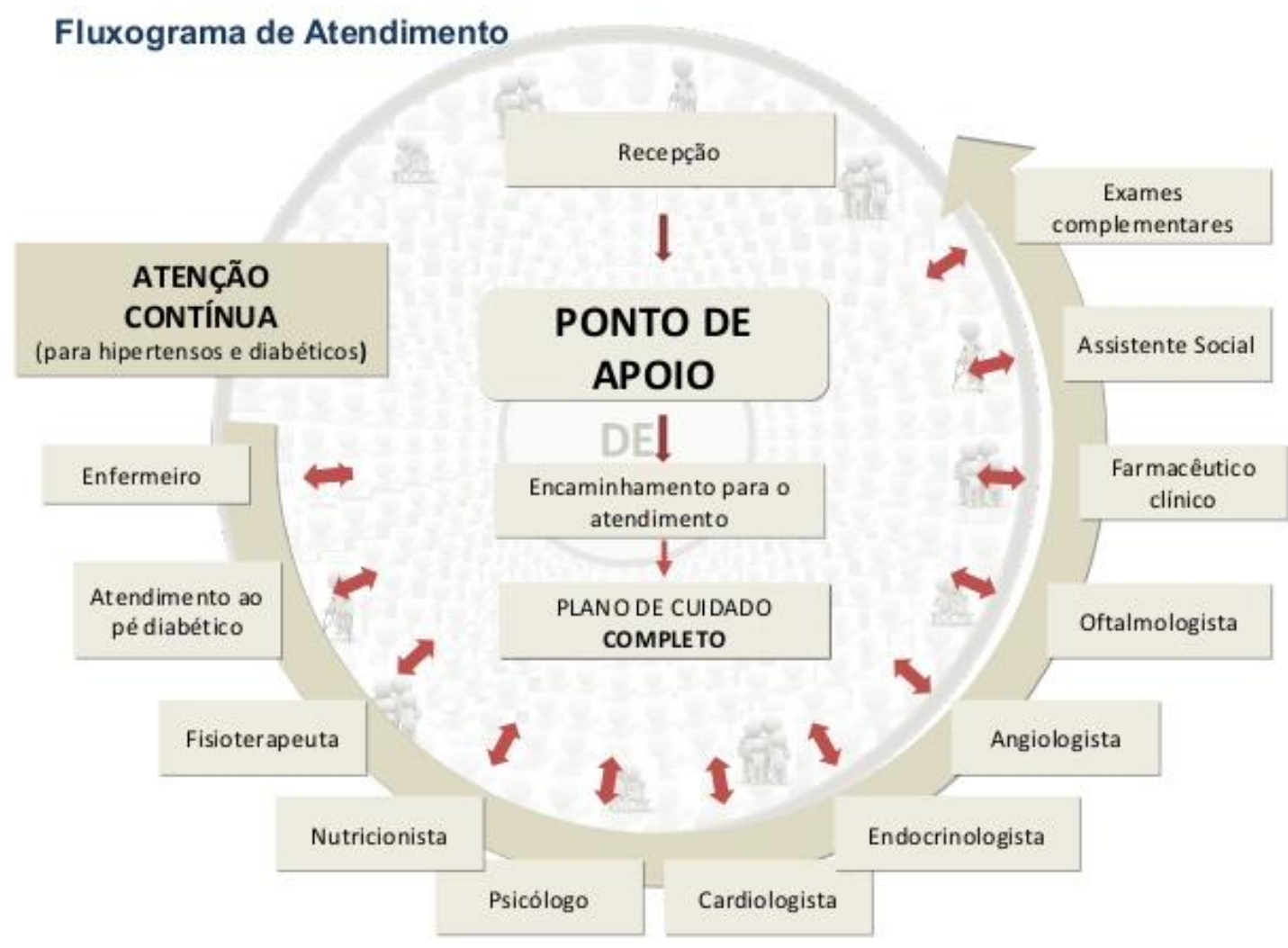

FONTE: CONASS, 2015

Dessa forma, ao refletir sobre a organização de serviços de saúde para o atendimento de pessoas com diabetes que autoadministram insulina, vislumbramos 0 modelo de Rede de Atenção à Saúde (RAS) para essa população. Estudos que abordam essa temática são respaldados no sentido de minimizar complicações advindas do insucesso dessa terapia no organismo do usuário, repercussões na família, nos sistemas de saúde e nos dados epidemiológicos que apontam curva crescente de números de pessoas com diabetes nas próximas décadas.

Com o intuito de compreender os processos de trabalhos do cuidado às pessoas adultas insulinodependentes sob a ótica de usuários, este estudo possibilita a investigação da experiência desses usuários como operadores de sua própria saúde. Assim, percebe-se que a problemática da gestão terapêutica do portador de DM em insulinoterapia perpassa desde a gestão do cuidado realizado pelo próprio usuário, passa pelo cuidado prestado pelos profissionais de saúde e chega até aos problemas administrativos advindos da gestão do próprio serviço de saúde. 


\section{3 - PRESSUPOSTOS DO ESTUDO}

Com base na literatura até aqui exposta, discutimos algumas concepções conceituais sobre DM e o uso de insulina, como também aspectos sociais e culturais que influenciam na gestão do regime terapêutico. Assim, com base na literatura, podemos dizer que, muitas vezes, os usuários com DM em uso de insulina vivenciam vários sentimentos que prejudicam a gestão do seu regime terapêutico.

Dessa forma, a gestão do cuidado sofre influência das características de cada pessoa, como a busca constante por conhecimento e habilidades para satisfazer as necessidades dos usuários, levando em consideração o nível de aprendizagem e as características socioculturais de cada um.

Ao mesmo tempo, entendemos que para a gestão do cuidado se realizar de forma adequada, o usuário com DM necessita de um acompanhamento de equipe multiprofissional treinada, e de sistema de serviço de saúde que garanta o acesso do usuário, por meio da atenção primária estruturada que assegura a inserção desse indivíduo na RAS.

Outras proposições foram levantadas a partir das referências consultadas, como: pessoas com DM em uso de insulina podem ter uma vida saudável; a educação em saúde é uma das estratégias utilizadas para promover o cuidado de pessoas com diabetes e pode ser desenvolvida tanto individualmente quanto pela participação em grupos de convivências; para que os usuários modifiquem seus comportamentos, fazse necessário o auxílio de profissionais de saúde e o apoio de seus familiares e que o portador de DM é o protagonista da gestão do seu cuidado.

Por conseguinte, a experiência de viver com diabetes e o uso de insulina expõe a preocupação de compreender como os usuários vivem nesse mundo, o entendimento da experiência permite que, a partir dos acontecimentos relatados, poderemos conseguir analisar as estratégias de gestão do cuidado para o manejo do DM.

Contudo é necessário dar voz as experiências e aos saberes construídos ao longo do processo do adoecer e do tratamento vivenciados pelos usuários diabéticos, pois só assim poderemos oferecer subsídio para auxiliar o gerenciamento do cuidado da condição crônica advinda do DM. 


\section{CAPÍTULO 3 - CAMINHO METODOLÓGICO}

\section{1 - PRINCÍPIO METODOLÓGICO}

Para alcançar o objetivo deste estudo, optou-se pela a pesquisa social estratégica em uma abordagem qualitativa. De acordo com Bulmer (1978), citado por Minayo (2014, p. 50), a pesquisa estratégica é a mais apropriada para o conhecimento e a avaliação de problemas e políticas do setor Saúde. Ainda segundo Minayo (2014, p. 24), a pesquisa qualitativa estuda o mais profundo das relações dos processos e o principal elemento analisado é o universo dos significados.

A abordagem qualitativa de pesquisa é uma prática que assume uma postura interpretativa em relação ao mundo, por meio de uma série de técnicas como: notas de campo, entrevistas, diálogos, figuras e gravações, ou seja, o pesquisador tenta compreender os sentidos que as pessoas atribuem para um determinado fenômeno, e é em torno desse sentido que elas organizam suas vidas (FLICK, 2009), inclusive a prática da gestão do cuidado com a sua saúde.

Dessa forma, a proposta envolve a aproximação do pesquisador à realidade sobre a qual formulou a pergunta para estabelecer uma relação com os atores sociais para a construção do conhecimento. Os participantes do estudo foram questionados sobre sua realidade e, nesse momento, além da descrição, promovem interpretações de acordo com o conjunto de conhecimentos que detêm.

\section{2 - CAMPO DE ESTUDO}

O Campo é o recorte espacial que o pesquisador faz para representar uma realidade empírica a ser estudada a partir das concepções teóricas que fundamentam o objeto da investigação (MINAYO, 2014, p. 201). Assim, optou-se por buscar pelo usuário desse estudo num local em que fosse possível a aproximação da sua realidade. Essa investigação então foi realizada em UBS localizada em CeilândiaDistrito Federal.

Atualmente essa UBS executa vários projetos que auxiliam os usuários com DM a desenvolverem atividades para melhoria em sua qualidade de vida, tais como: atividade física tradicional, palestras, consultas individualizadas, assim como práticas integrativas e complementares. 
A escolha por esse local se deu pelo fato de ter observado a participação da população diabética em atividades educativas, assim como interesse na prática do automanejo e a receptividade dos funcionários em receber pesquisadores, com a finalidade de melhorar a assistência prestada aos diabéticos insulinotratados.

A população urbana de Ceilândia é estimada de 449.592 habitantes, distribuídos em uma área de 29,10 km² (DISTRITO FEDERAL, 2013). Essa Regional Administrativa de Saúde do Distrito Federal teve seu nome modificado para Superintendência de Saúde Oeste, com a publicação do Decreto n.ํ 37.057, no dia 15 de janeiro de 2016, que reestrutura a gestão do Distrito Federal e cria uma nova instância de administração. Atualmente, essa superintendência abrange tanto a região de Ceilândia como a de Brazlândia (BRASIL, 2016).

A Região de Ceilândia é subdividida em diversos setores: Ceilândia Centro, Ceilândia Sul, Ceilândia Norte, P Sul, P Norte, Setor O, Expansão do Setor O, Quadra Norte Q (QNQ), Quadra Norte R (QNR), Setores de Indústria e de Materiais de Construção, Parte do Instituto Nacional de Colonização e Reforma Agrária - INCRA (área rural), Condomínio Privê, e os Condomínios Pôr do Sol e Sol Nascente, que se encontram em processo de regularização (DISTRITO FEDERAL, 2013; SEVERO, 2014).

Segundo a Secretaria de Estado de Saúde do Distrito Federal (2015), a rede pública de saúde de Ceilândia é composta por: (1) um Hospital Regional, (12) doze UBS, (1) um Centro de Atenção Psicossocial Álcool e Drogas (CAPSAD), (1) uma Unidade de Pronto-Atendimento (UPA) e (1) um Laboratório Regional (DISTRITO FEDERAL, 2015).

\section{3 - TRABALHO DE CAMPO}

Para utilizar o cenário de estudo, solicitamos autorização escrita, por meio de carta de concordância da Diretoria da UBS e do Coordenador Geral da Regional de Saúde de Ceilândia, naquele momento, a estrutura organizacional se configurava dessa forma. Nesse pedido apresentamos o projeto contendo o objetivo e justificativa da pesquisa, os procedimentos para a coleta de dados e como seriam apresentados no texto final, respeitando a privacidade dos usuários.

No documento, frisamos que no desenvolvimento da pesquisa partimos do princípio do respeito à dignidade do Ser Humano, de acordo com a Resolução n.o 
466/2012, do Conselho Nacional de Saúde, que apresenta as diretrizes e normas que regulamentam a pesquisa envolvendo seres humanos (BRASIL, 2012).

Em agosto de 2015, iniciou-se o estudo, em que participamos de atividades programadas pelos profissionais da UBS, nos encontros semanais de educação em saúde, por meio de palestras e nas atividades físicas desenvolvidas às sextas-feiras. Assim, pudemos aproximar da realidade dos usuários e entender como funciona a instituição de saúde pesquisada, ou seja, o trabalho de campo:

Permite a aproximação do pesquisador da realidade sobre a qual formulou uma pergunta, mas também estabelece uma interação com os "atores" que conformam a realidade, e assim, constrói um conhecimento empírico importantíssimo para quem faz a pesquisa social (MINAYO, 2007, p.61).

\section{4 - PARTICIPANTES DE PESQUISA}

Participaram da investigação dez indivíduos adultos; entende-se por adulto as pessoas que se encontram com idade entre 18 a 59 anos (PIANCASTELLI, 2013). Os usuários apresentavam condições (física, cognitiva, mental) de exercer sua autonomia para decidir participar do estudo, após serem informados quanto aos objetivos, riscos possíveis, importância do estudo e assinar o Termo de Consentimento Livre e Esclarecido - TCLE (APÊNDICE I).

Os dez usuários foram selecionados dentre os 57 usuários cadastrados na UBS que se encontravam em insulinoterapia e na faixa etária estudada. Para participar da pesquisa foi necessário que os usuários estivessem em tratamento de DM, que praticassem o automanejo da insulina, e fossem cadastrados e acompanhados na UBS como pessoa com diabetes e que fizessem uso de insulina, no mínimo, há um ano. Este último aspecto foi considerado, uma vez que o uso de insulina menor que um ano dificulta a adesão do usuário ao tratamento, pois, conforme Villas Boas, Lima e Pace (2014), a maior adesão à insulina é atribuída ao longo tempo de diagnóstico do DM, bem como à presença de complicações. Vale salientar que não participaram do estudo usuários com DM gestacional e aqueles que apresentaram confusão mental.

Foram entrevistados doze (12) usuários, de ambos os sexos. Foram excluídas do estudo duas entrevistas; a primeira, pelo fato de que, durante a coleta de dados, a entrevistada relatou que havia parado de utilizar insulina por conta própria, havia mais de seis meses e ainda não tinha informado aos profissionais da UBS sobre sua decisão. Como essa postura colocava em risco a vida da usuária, foi necessário 
comunicar ao enfermeiro responsável pelo acompanhamento da mesma, a fim de minimizar os problemas decorrentes da hiperglicemia. Já a segunda entrevista foi excluída pelo fato de que, durante o relato da descoberta da doença e de acordo com os exames médicos apresentados, não foi possível identificar se a usuária era portadora de DM Gestacional, visto que a mesma afirma que descobriu ser portadora de DM após um aborto espontâneo. Assim, ao final, dez (10) usuários participaram do estudo.

\section{5 - COLETA DE DADOS}

Após a aprovação da pesquisa pelo Comitê de Ética, foi solicitada ao enfermeiro responsável pela assistência das pessoas com DM na UBS, planilha com os dados dos usuários diabéticos cadastrados. Esse documento contém informações como: nome, idade, telefone, últimas datas de consultas com enfermeiro e médico, número do cadastro na Secretaria do Distrito Federal, se o mesmo utiliza insulina e se ele faz uso do aparelho de glicemia fornecido pela secretaria. O conhecimento dessa planilha aconteceu durante o início do trabalho de campo.

Com essa planilha, foi confeccionado um segundo documento com os dados apenas dos usuários em uso de insulina. Dessa forma, em setembro de 2015, iniciouse o contato com pessoas que atendiam aos critérios de inclusão desta pesquisa por meio de ligações telefônicas. Nessas ligações, a pesquisadora se apresentava e convidava os usuários aptos a participarem de uma entrevista (APÊNDICE II).

A entrevista era constituída por uma conversa que incluiu demonstração simulada da prática do manejo da insulina por parte do usuário, realizada no dia e horário marcados, em ambiente reservado na própria instituição, com garantia de privacidade, preservação de identidade e sigilo de respostas. A conversa foi norteada por: "Descreva-me a experiência de viver com diabetes e realizar o uso de insulina".

Para simulação, dispusemos sobre uma mesa - seringa de $1 \mathrm{~mL}$ (graduada em 100 unidades), com agulha acoplada de $6 \mathrm{~mm}$, frasco-ampola contendo líquido leitoso (similar insulina NPH), frasco-ampola com líquido transparente (similar a insulina Regular), algodão e álcool. Assim, os usuários foram solicitados a realizarem o procedimento de forma habitual. $\mathrm{Na}$ observação direta do procedimento, a pesquisadora permaneceu ao lado do usuário durante todo o procedimento, observando e anotando os achados referentes à prática realizada. 
O tempo estimado para cada entrevista foi de aproximadamente sessenta (60) minutos, reduzido ou prolongado de acordo com a disponibilidade e receptividade do usuário. A entrevista foi gravada digitalmente, no intuito de otimizar a transcrição dos dados, sendo o entrevistado informado da gravação, e também de que as informações nelas obtidas seriam utilizadas somente para a realização da pesquisa e divulgação da mesma.

A coleta de dados foi encerrada quando as entrevistas passaram a apresentar repetições em seu conteúdo, atingindo a saturação de dados. De acordo com Fontanella, Ricas e Turato (2008), o número de entrevistas, para que haja saturação dos dados, está em torno de dez a quinze entrevistados. Assim como para ThiryCherques (2009), o ponto de saturação somente é atingido quando nenhuma nova informação ou novo tema é acrescentado ao fenômeno que é pesquisado.

\section{6 - ANÁLISE DE DADOS}

As entrevistas gravadas foram transcritas integralmente pela pesquisadora e em seguida submetidas à Análise de Conteúdo, na modalidade temática. A Análise de Conteúdo, de acordo com Bardin (2009, p.15), consiste de:

Um conjunto de técnicas de análise das comunicações visando obter, por procedimentos sistemáticos e objetivos de descrição do conteúdo das mensagens, indicadores (quantitativos ou não) que permitam a inferências de conhecimentos relativos às condições de produção/recepção (variáveis inferidas) destas mensagens.

Nesse sentido, essa forma de análise permitiu articular os textos analisados aos fatores que determinam suas características (sejam eles psicossociais, culturais ou o contexto). A análise temática, opção técnica deste trabalho, consistiu, de acordo com Minayo (1996, p.209), em "descobrir os núcleos de sentido que compõem uma comunicação cuja presença signifique alguma coisa para o objetivo analítico visado".

No primeiro momento, realizou-se a exploração do material com leitura exaustiva das falas. Em seguida, as respostas dos usuários foram agrupadas e sintetizadas sobre o conteúdo de cada um dos participantes. Após, foram identificados os núcleos do sentido extraídos das falas dos entrevistados, agrupados de acordo com a unidade temática. Nesse processo, obtivemos as categorias de análise dos dados. A síntese geral abordou os significados trazidos pelos participantes deste estudo. 


\section{7 - ASPECTOS ÉTICOS}

O estudo seguiu a Resolução n. ${ }^{\circ}$ 466/2012, do Conselho Nacional de Saúde/Ministério da Saúde, a qual norteia o princípio de autonomia, por meio da assinatura do TCLE, instrumento imprescindível que pressupõe da troca de informações entre o pesquisador e o participante, no qual aponta os objetivos, benefícios, riscos e as várias etapas da pesquisa que compreende desde a coleta de dados até a sua divulgação (GUZ, 2010).

O anonimato dos participantes ficou garantido com a substituição dos nomes dos participantes pelo termo entrevista, acompanhado de um algarismo romano sequencialmente (entrevista I a entrevista X), e os participantes do estudo foram informados que a sua participação na pesquisa não os prejudicaria e não influenciaria no trabalho desenvolvido pela UBS, visto o sigilo dos relatos.

Os participantes deste estudo foram expostos a riscos, a que se buscou serem minimizados, pois alguns apresentaram alterações emocionais e desconforto ao compartilhar informações pessoais ou confidenciais na entrevista.

Como benefício, após a defesa da dissertação, os resultados estarão disponíveis na Superintendência de Saúde Oeste, e posteriormente serão publicados.

A pesquisa foi aprovada pelo Comitê de Ética e Pesquisa da Fundação de Ensino e Pesquisa em Ciências da Saúde (FEPECS), da Secretaria Estadual de Saúde do Distrito Federal, com o número de Parecer n.ำ 1.037.214. 


\section{CAPÍTULO 4 - RESULTADOS}

A seguir, serão apresentados os resultados de acordo com os objetivos propostos no presente estudo. Primeiro, a caracterização dos usuários e, posteriormente, as duas categorias que emergiram durante a análise temática das transcrições: a experiência dos usuários insulinotratados em viver com a sua condição crônica e administrar a insulina, e a gestão do cuidado no manejo da insulina. A primeira categoria se desdobrou em duas subcategorias: a experiência dos diabéticos em viver com sua condição crônica e a insulinoterapia na visão dos diabéticos. Já a segunda categoria emergiu em três subcategorias: armazenamento e transporte da insulina, técnica de preparo da insulina e técnica de aplicação da insulina.

\section{1 - CARACTERIZAÇÃO DOS PARTICIPANTES}

O estudo foi realizado com dez usuários que vivem com DM e autoadministram insulina, sendo a maioria do sexo feminino e com idade entre 47 e 59 anos. Também observou que o número de casados era igual ao número de solteiros; e que a ocupação mais frequente era de servidores públicos. Quanto à escolaridade e à renda familiar, houve um predomínio de ensino médio completo e renda familiar de $\mathrm{R} \$ 881,00$ a $\mathrm{R} \$ 2.640,00$, conforme Tabela 1.

Tabela 1 - Distribuição quanto ao número $(\mathrm{N})$ e porcentagem (\%) dos entrevistados, segundo as variáveis sociodemográficas. Ceilândia, Brasília, 2016

\begin{tabular}{lrrr}
\hline & Característica & $\mathrm{N}$ & $\%$ \\
\hline Idade (anos) & & & \\
& 47 a 50 anos & 3 & $30 \%$ \\
Sexo & 51 a 54 anos & 2 & $20 \%$ \\
& 55 a 59 anos & 5 & $50 \%$ \\
Estado Conjugal & Feminino & 6 & $60 \%$ \\
& Masculino & 4 & $40 \%$ \\
& Estável & 1 & $10 \%$ \\
& Casado (a) & 3 & $30 \%$ \\
Escolaridade & Solteiro (a) & 3 & $30 \%$ \\
& Viúvo (a) & 2 & $20 \%$ \\
& Divorciado (a) & 1 & $10 \%$ \\
Ocupação & & 3 & $30 \%$ \\
& Ensino Fundamental Incompleto & 3 & $10 \%$ \\
& Ensino Fundamental Completo & 1 & $20 \%$ \\
Ensino Médio Incompleto & 2 & $40 \%$ \\
\hline
\end{tabular}




\begin{tabular}{lrrr}
\hline & Servidor (a) Público (a) & 3 & $30 \%$ \\
Aposentado (a) & 1 & $10 \%$ \\
Pensionista & 1 & $10 \%$ \\
Desempregado (a) & 1 & $10 \%$ \\
Comerciante & 2 & $20 \%$ \\
Cozinheira (o) & 1 & $10 \%$ \\
& Açougueiro (a) & 1 & $10 \%$ \\
& & \\
& Até $\mathrm{R} \$ 880,00$ & 1 & $10 \%$ \\
& $\mathrm{R} \$ 881,00$ a $\mathrm{R} \$ 2640,00$ & 6 & $60 \%$ \\
$\mathrm{R} \$ 2641,00$ a $\mathrm{R} \$ 5280,00$ & 2 & $20 \%$ \\
Mais de $\mathrm{R} \$ 5280,00$ & 1 & $10 \%$ \\
\hline
\end{tabular}

O tempo de diagnóstico do DM variou de dois a vinte anos, já o tempo de insulinoterapia esteve entre dois a quinze anos. Em relação ao tipo de insulina utilizada para o tratamento da hiperglicemia, todos os usuários relataram fazer uso da insulina humana NPH, de acordo Tabela 2.

Tabela 2 - Distribuição quanto ao número (N) e porcentagem (\%) dos entrevistados, segundo o tempo de diagnóstico, tempo de insulinoterapia e tipo de insulina utilizada.

Ceilândia, Brasília, 2016

\begin{tabular}{lrrr}
\hline & Característica & $\mathrm{N}$ & $\%$ \\
\hline Tempo de Diagnóstico & 2 a 6 anos & 4 & $40 \%$ \\
& 7 a 11 anos & 2 & $20 \%$ \\
& 12 a 16 anos & 2 & $20 \%$ \\
Tempo de Insulinoterapia & 17 a 20 anos & 2 & $20 \%$ \\
& 2 a 6 anos & 7 & $70 \%$ \\
Insulina utilizada & 7 a 11 anos & 2 & $20 \%$ \\
& 12 a 15 anos & 1 & $10 \%$ \\
& NPH & 7 & $70 \%$ \\
\hline
\end{tabular}

\section{2 - A EXPERIÊNCIA DOS INSULINOTRATADOS EM VIVER COM A SUA CONDIÇÃO CRÔNICA E ADMINISTRAR A INSULINA}

As experiências levantadas por este estudo sobre a temática de viver com diabetes e fazer o uso de insulina possibilitou conhecer algumas interfaces existentes no cotidiano da vida dos diabéticos insulinotratados, que serão descritas nos subitens abaixo.

\subsection{1 - A experiência dos diabéticos em viver com sua condição crônica}

Nessa categoria foi possível reconhecer que ao descobrir a sua condição crônica os usuários vivenciaram emoções ligadas ao medo, ansiedade e depressão; pois viver 
com o DM é uma experiência negativa; sendo que o diagnóstico da doença aconteceu logo após surgirem os sinais e sintomas de hiperglicemia; e acreditam ter adquirido essa condição devido ao estilo de vida não saudável. Referiram que o DM não possui cura, apesar da cura divina ser esperada. Durante as entrevistas revelaram a proximidade do DM com outras doenças, como a Síndrome da Imunodeficiência Adquirida (Aids), problemas cardíacos e o câncer. Percebemos que os usuários com menos de cinco anos de diagnóstico de DM tiveram maior aceitação ao tratamento proposto e a adesão à prática de autocuidado, que a maioria dos usuários não souberam relatar o tipo de diabetes que possuíam, e as principais dificuldades para o manejo de DM foi seguir uma dieta hipoglicemiante, praticar atividade física e lidar com o isolamento social advindo do uso da insulina.

Assim, os usuários deste estudo ressaltaram que viver com DM é algo "desagradável", "perigoso", "péssimo", "horrível", "assustador", que causa ansiedade, medo e depressão:

Vou te falar uma coisa, viu, não é agradável não [...] sabe que vai mexer no seu organismo todinho, né! Mexe com o coração, mexe com o pulmão, mexe nas pernas, né! Aquela coisa toda, né! [...] Sei que é uma coisa muito perigosa sabe é muito perigoso e tudo mais (Entrevista I).

Horrível [...] Péssimo, horrível, né! (Entrevista II).

Não, na verdade eu fiquei com um pouco de medo (Entrevista VI).

A descoberta da condição crônica de todos os usuários se deu por meio da apresentação em domicílio dos sinais e sintomas de hiperglicemia e, posteriormente, a confirmação no serviço de saúde, como também que ao descobrir DM, apenas um usuário não se preocupou com seu diagnóstico:

Não fiquei preocupado não, porque eu nem sabia que era isso, porque na família nunca teve, aí apareceu em mim e depois na minha irmã. Já depois de velho já [...] É, a gente acostuma a conviver com o diabetes, tem que conviver, né! (Entrevista IX).

Ah, na verdade, eu passei mal à noite [...] aí eu fui no posto de saúde e a atendente perguntou lá pra mim: Vem cá, você é diabético? Eu falei não. Aí falou: Então faz o seguinte, amanhã de manhã tu vai lá no [outro] posto e mede a glicose. Aí, eu fui no outro posto, medi e tava 416, aí eu não sabia que era diabético e nem nada [...] logo eu já comecei a emagrecer, porque eu tava bem gordinho, aí eu já comecei a emagrecer [...] (Entrevista VI).

Aí que "tá", foi de repente em casa, começou uma secura na boca e urinando, uma urina grossa com cheiro forte, e aquilo começou a 
apertar e a boca secando, parecia que eu ia morrer sufocado, aí corri aqui, e eu não sabia que tinha isso, eu não tinha mesmo, ninguém na família tinha, aí constou isso. O médico pediu que eu tomasse logo a insulina e já passou esse remédio (Entrevista IX).

Olha, ficou tudo normal, a única coisa é que eu emagreci demais, no começo fiquei só a pele e o osso mesmo e todo mundo pensava que era virose. Falava que era virose, porque vomitava, dava diarreia e eles falam que era virose (Entrevista II).

Os usuários acreditam ter desenvolvido DM devido à alimentação não saudável:

Eu acho que a minha diabetes foi quando eu morava sozinho, eu tomava muito [refrigerante], só pode ter sido isso, o dia todo. Comprava dois litros de [refrigerante], rapidinho ela acabava, aí eu ia lá e comprava mais dois (Entrevista II).

Eu fiquei mais ou menos uns 3 anos no Hospital de Apoio, depois no Hospital de Base, com ele [esposo]. Eu nem vinha em casa, eu ficava lá, aí sabe aquela correria, você não ter tempo de comer, comia tudo e aquela ansiedade de comer de tudo, aí comecei a engordar (Entrevista V).

Durante as entrevistas, o DM foi diversas vezes comparado com outras doenças graves, como a Síndrome da Imunodeficiência Adquirida, problemas cardíacos e o câncer:

Igual a pessoa que tem Aids, sabendo que aquilo não tem a cura (Entrevista I).

Acho que o câncer, o câncer terminal [...] O câncer eu acho que é igual, ou então a Aids; Aids porque também vai destruindo o corpo, né? Se tiver uma pneumonia, a pessoa morre de Aids, né? (Entrevista III).

A diabetes ela é muito perigosa, eu compararia com o coração, porque o coração se você não cuidar ele te mata, né, e a diabetes também, se você não cuidar ela vai te matar (Entrevista II).

De forma geral, os usuários têm ciência de que o DM é uma doença crônica incurável, mas alguns acreditam na possibilidade da cura divina:

Uma doença que, como se fala, é incurável, né, que vou morrer com ela, não, pra mim não tem não [cura], porque a tendência dela pra mim só tá aumentando, só tá me matando aos poucos (Entrevista IV).

Mas a cura vem de Deus, sabe! (Entrevista I).

Mas fez eu me pegar mais com Deus, porque tudo Ele pode, né! (Entrevista III). 
Em relação ao tempo de diagnóstico, observou-se que os usuários que possuíam menos de cinco anos de descoberta da doença tiveram maior aceitação ao tratamento proposto e adesão à prática de autocuidado, quando comparado com aqueles que tinham mais de dez anos:

Falei pra meus meninos que eu não quero nem mais viver, eu já vivi muito, tava tomando era cachaça (Entrevista X, dez anos de diagnóstico da doença).

É, às vezes eu como e depois eu lembro, e às vezes eu tô sabendo que tá errado, mas eu tô fazendo, comecei a fazer natação, comecei a fazer hidroginástica, aí largo tudo (Entrevista $\mathrm{V}$, doze anos de diagnóstico da doença).

Depois do banho, eu procuro secar bem sequinho [pés], agora eu estou com sandália, mas eu gosto de andar com sapatinho fechado (Entrevista VII, cinco anos de diagnóstico da doença).

Faço caminhada, às vezes faço bicicleta em casa quando não dá para fazer uma caminhada, eu uso mais é o adoçante (Entrevista IX, dois anos de diagnóstico da doença).

Quando perguntados sobre o tipo de diabetes que possuíam, a maioria dos usuários não souberam responder com exatidão a essa pergunta:

\author{
Eu não lembro, qual que é o mais assim [...] Eu acho que é o 2 \\ (Entrevista VII). \\ Pois é, me parece que é o 2 ou o 1, sei lá (Entrevista V). \\ Eu não sei (Entrevista IV).
}

As principais dificuldades relatadas pelos usuários relacionadas ao manejo do DM foram: seguir uma dieta hipoglicemiante e praticar atividades físicas:

Eu tenho dificuldade e a profissão não deixa a gente fazer esses regimes que pede. Porque a alimentação, se não for forte, não dá conta. São 12 horas de serviço por dia e em pé, então é complicado. E ela exige, principalmente arroz, feijão, isso aí não pode faltar na alimentação e é meio exagerado, né (risos). Às vezes, ela sobe demais e eu sou obrigado a maneirar, mas dá uma fome "danada" logo em seguida. Aí vai massa, que é uma coisa que não pode também, né?. Mas é o que sustenta, por incrível que pareça é o que mata a fome (Entrevista IX).

Eu faço quinze dias de dieta e quinze é de pé na jaca, come o que tem, a renda não dá (Entrevista IV). 
Aí minha esposa fala assim: Mas você praticava esporte, fazia isso... e aquilo, né! Aí vem o comodismo, né! Aí você fala assim amanhã eu vou praticar um esporte aí você não vai, deixa que domingo eu vou, aí você não vai. Aí vai acomodando [risos] (Entrevista I).

Percebe-se, nas falas que a dieta, o fator financeiro e o comodismo também interferem diretamente no tratamento do DM, dificultando o seguimento de uma dieta hipoglicemiante e a prática de atividade física.

Além das dificuldades em seguir uma dieta hipoglicemiante e praticar atividade física, os usuários também relataram que sofrem por causa das brincadeiras realizadas pelos amigos e devido ao isolamento social.

Aí o cara chega: Toma aí um copo de [refrigerante]. Não, num tô a fim não. Bebe aí, cara. Não, não! Aí um fala assim: Ele num pode, ele é diabético. Aí o cara fala: Ah, mas eu sou de Anápolis. Aí quer dizer aquilo ali, sabe, incomoda (Entrevista II).

Seus amigos é só naquele exato momento quando você tá bem, aí o pessoal vira as costas, entendeu? Aí o único amigo que você tem é Deus, em primeiro lugar, e sua família (Entrevista I).

Dessa forma, as principais dificuldades para o manejo dessa condição crônica é seguir uma dieta hipoglicemiante, praticar atividade física e lidar com o isolamento social.

\subsection{2 - A insulinoterapia na visão dos diabéticos}

A descoberta da necessidade do uso de insulina fez com que os usuários vivenciassem sentimentos de medo, raiva, angústia, ansiedade, susto e depressão, pois a obrigatoriedade do uso contínuo da insulina incomoda os usuários; além de faltar fitas reagentes para realização do teste de glicemia periférica, também faltam medicamentos na UBS, e carregar as agulhas e seringas em público causa receio.

Ao descobrir que era necessário realizar a insulinoterapia, vários sentimentos foram vivenciados pelos usuários, como medo, raiva, angústia, ansiedade, susto e depressão:

Não, na verdade eu fiquei com um pouco de medo. Porque o pessoal olha pro diabético... A partir do momento que ele toma insulina, já era pra ele; aqueles comentários, né? (Entrevista VI).

Ah, minha filha, raiva, angústia, sabe, aquela angústia doida. Aí, eu dizia: Ah, se for pra mim tomar insulina, prefiro morrer, eu preciso 
suicidar. Entrei em depressão mesmo. Cheguei a pesar 40kg, sabia? (Entrevista X).

Observa-se, nas falas, que 0 ato de aplicar a insulina diariamente incomoda os insulinodependentes, e os usuários demonstram desejo em se libertar dessa rotina:

Eu, por mim, eu não usava a insulina, eu tava até pensando que eu vou
voltar no endocrinologista pra ver se eu consigo me libertar dessa
insulina, porque isso é muito chato (Entrevista V).

Porque incomoda muito de manhã [...] Ah, sei lá, de todos os dias pela manhã ter aquele processo de ser furada [...] Eu nem sei dizer, é uma coisa assim que eu queria deixar, né! (Entrevista VII).

Os usuários relataram que a maioria dos insumos necessários para o seu tratamento - como insulinas, seringas, agulhas - são fornecidos pela UBS ou pela farmácia popular; porém, quando faltam insumos, influencia diretamente na renda familiar e na terapêutica dos mesmos. Assim, um usuário relata que utiliza como estratégia a economia para não ficar sem as fitas que auxiliam no seu tratamento, realizando a verificação da glicemia capilar em quantidades inferiores ao orientado para esse usuários:

Não, porque não tem fita aqui. Pego aqui [...] Eu pego aqui no posto, eu pego três caixinhas [...] Não olhei [glicemia]... Aí vai no "escuro", o que eu faço: eu vejo o que eu tô sentindo, entendeu? E tomo 10 [unidades], "tiro" no escuro. Ontem eu tomei cinco. As minhas acabaram segundafeira [as fitas]. Aí eu vim aqui e não tinha. Eu fui em outros postos e eles disseram que não entregam, nem se tivessem eles não entregam, eu fico assim nervoso, porque eu sinto que ela "tá" alta, mas não sei a quantidade (Entrevista II).

Chego aqui no posto e tá faltando remédio, eu tenho que comprar. Aí eu não tenho dinheiro pra comprar, aí tem que pedir um filho pra comprar. O filho não tem dinheiro pra comprar, isso já me deixa triste. Tá faltando alguma coisa, eu sempre tenho que tá pedindo para os outros. Eu chego no posto, não tem; é o que tá acontecendo agora (Entrevista III).

$\mathrm{Na}$ verdade, eu economizo as fitinhas também, né? Senão acaba as fitinhas, e elas estão aqui sempre em falta... olha, eu olho umas quatro vezes por semana... eu não olho todo dia, não (Entrevista VI).

Os usuários relataram que sentem receio em carregar as agulhas e seringas em público, pois a população pode confundir que eles fazem uso de drogas ilícitas:

Eu tenho receio, se a gente sair com uma sacola dessa ali no meio da rua, drogada, tá com uma sacola cheia de seringa, isso é terrível! (Entrevista III). 


\section{3 - GESTÃO DO CUIDADO NO MANEJO DA INSULINA}

Ao analisar a gestão do cuidado no manejo da insulina, observamos por meio das falas e das simulações realizadas, que os usuários apresentaram diferentes comportamentos relacionados ao armazenamento, transporte, preparo e aplicação da insulina.

\subsection{1 - Armazenamento e transporte da insulina}

Em relação ao armazenamento da insulina e da seringa, a maioria dos usuários relatou armazenar esses insumos na geladeira e apenas um armazena em cima de um móvel.

Fica na geladeira (Entrevista VIII).

Fica em cima do armário (Entrevista I).

Quanto ao local da geladeira que os usuários utilizam para armazenar a insulina e as seringas, a maioria dos usuários referiu que colocam na porta, alguns na gaveta e um no congelador.

$\mathrm{Na}$ porta da geladeira, tem uma vasilhinha de plástico assim, aí eu fecho com saco plástico e esse saco plástico eu troco ele uma vez por semana (Entrevista VII).

Na gaveta da geladeira, aonde ficam as verduras (Entrevista IV).

$\mathrm{Na}$ verdade, sempre mantenho ela no congelador (Entrevista $\mathrm{VI}$ ).

No caso de falta de energia, a maioria dos usuários apontou que colocam a insulina em uma vasilha com gelo em gel reciclável, alguns afirmaram que colocam dentro do congelador, e apenas um disse que caso percebesse que a insulina estava com a temperatura acima do habitual, ele a desprezaria.

Aconteceu uma vez, eu peguei e joguei fora, porque esquentou (Entrevista VII).

Quando acaba [energia elétrica], eu tiro ela da vasilha e coloco dentro do congelador (Entrevista IV). 
Aí eu pego esse gel, que te falei, ponho na vasilha e ponho elas, até chegar a energia (Entrevista II).

A data de validade e o prazo para o consumo da insulina não são observados pela maioria dos usuários, e as insulinas, após abertas, são geralmente utilizadas até a última dose do frasco.

Você acredita que eu nunca fiz isso [se olhou a validade da insulina] (Entrevista V).

Dá, dá mais de 30 dias (Entrevista VI).

Uso uns dois meses (Entrevista VIII).

Quanto ao transporte da insulina da UBS para a residência dos usuários, ocorre com armazenamento em bolsas e sacolas. Já no caso de viagens, os usuários relataram que transportam a insulina em caixa de isopor com gelo.

Pensa que sacrifício, é difícil para viajar, você tem que encher de gelo, colocar dentro da vasilha de isopor com gelo, aí se o gelo acabar tem que parar em restaurante e comprar para colocar mais (Entrevista $\mathrm{X}$ ).

Dentro da bolsa, eu coloco dentro de uma sacola, dentro da bolsa e vou direto pra casa (Entrevista IV).

\subsection{2 - Técnica de preparo da insulina}

Durante a simulação da prática de autoadminsitração de insulina, observou-se que nenhum usuário realiza a assepsia do frasco, somente um realiza a higienização das mãos antes de pegar a insulina e que cinco usuários descreveram que homogeneizam a insulina antes de administrá-la.

Eu lavo as mãos, aí eu pego e viro ela umas duas vezes (Entrevista VIII).

Pego, dou uma rodadinha (Entrevista IX).

Eu tenho que sacolejar (Entrevista X).

Nas observações realizadas durante as simulações de aspiração de insulina, observou-se que nenhum dos usuários injetou o ar dentro do frasco de insulina para auxiliar na aspiração, e que somente um realizou a aspiração da quantidade correta de insulina sem desperdiçar a medicação e sem deixar bolha de ar na seringa. 
Foi observado também que os usuários apresentaram dificuldades para visualizar as marcações das unidades existentes nas seringas de 100 unidades, disponibilizadas na UBS para a administração de insulina.

\subsection{3 - Técnica de aplicação da insulina}

Em relação à reutilização da seringa/agulha, foi relatado que, no mínimo, as mesmas são utilizadas em duas aplicações e no máximo 14 aplicações, tendo em média a reutilização desses insumos em seis aplicações:

Quando eu vejo que ela tá cega, quando ela não quer entrar, aí eu já sei, umas seis ou sete, por aí [se referindo à quantidade de aplicações por seringas], umas seis, sete vezes, quando eu vejo que ela não quer entrar, eu não utilizo mais (Entrevista III).

Observou-se também que alguns usuários adeptos a prática de reutilização de seringas e agulhas utilizam o álcool para a sua limpeza:

Passo álcool na agulha e puxo o álcool, até fazer a próxima (Entrevista II).

Passo o álcool, passo o álcool na agulha primeiro, tampo, ponho na mesa (Entrevista VII).

Durante a pesquisa, vários usuários afirmaram que as principais dificuldades relacionadas ao uso de insulina é a dor e o sangramento que aparecem quando a aplicação da insulina é realizada em locais errados ou quando reutilizam a seringa/agulha. Relataram ainda que retiram a insulina da geladeira e imediatamente aspiram a medicação para a sua administração:

Só sinto desconforto quando aplico no lugar errado. Só isso, dói e sangra (Entrevista III).

Eu pego, eu tiro ela [da geladeira] e aplico logo (Entrevista III).

Eu já sei, eu já sinto, como já tem muito tempo, quando eu pego ela,que eu vou furar e vejo que ela tá agarrando, eu já não uso, já jogo fora (Entrevista VII).

Em relação ao descarte correto das agulhas, observou-se que ele ainda não é seguido pela metade dos entrevistados: 
Deixo em uma caixinha de isopor. Fica tudo guardadinho, trago para o posto, entrego para as meninas que elas sabem o que fazem [descarte das agulhas] (Entrevista I).

Eu tô armazenando nas garrafas pet, lá em casa, até tem uma cheia. Eu trago pra cá, porque antigamente eu descartava no lixo. Eu não sabia, aí eu fui informada (Entrevista III).

Bom, na verdade, essa agulhinha aí eu pego ela e quebro a pontinha e coloco no saco de lixo. Não deixo ela com a ponta não, eu vou lá e quebro a agulhinha (Entrevista VI).

Os usuários entrevistados foram orientados quanto ao descarte do material perfurocortante pelos profissionais de saúde da UBS, porém não colocam em prática as orientações recebidas:

Eu estou descartando errado, tem que ser em uma garrafa plástica, mas eu estou pondo no lixo, é a pressa para ir trabalhar. Eu ponho tudo junto, porque só sou eu, aí é pouquinho lixo (Entrevista IX).

Quanto à realização de rodízio dos locais de aplicação da insulina, somente alguns entrevistados realizam essa prática, outro realiza o rodízio, mas aplica a insulina em um local não recomendável, e a maioria relata que não realiza essa prática devido às dificuldades encontradas em aplicar a insulina em outro local que não seja o abdome:

Eu aplico nos braços, aí tem vez que eu aplico na barriga e tem vez que na coxa. Eu vou sempre mudando (Entrevista II).

A agulha é bem pequenininha, né, e tem hora que você tem que tá brincando, eu passo sete dias aqui (braço), sete dias aqui (barriga), no bumbum, sempre mudando, né! os locais (Entrevista I).

Eu ando aplicando aqui na planta [se referindo ao músculo gastrocnêmico] da perna, só que é muito ruim (Entrevista V).

Eu só consigo aplicar só na barriga, nos braços eu não consigo (Entrevista X).

Deixei só para a barriga mesmo (Entrevista IX).

Os usuários relataram também que, quando estão fora do domicílio no horário de administrar a insulina, buscam ambientes como o sanitário para realizar tal procedimento:

Banheiro, escondida de todo mundo (Entrevista IV). 
Quando eu vejo que tá dando a hora, eu só entro no banheiro ali e aplico (Entrevista VI).

E dois usuários realizam a assepsia do local de aplicação com álcool antes da administração da insulina:

Aí, passo o álcool, o algodão com álcool, e aplico! (Entrevista III).

Nas observações realizadas durante as simulações de administração de insulina, verificou-se que nenhum usuário realiza a prega cutânea para administrar a medicação e que todos possuem dificuldades para autoadministrar a insulina nos membros superiores.

Desse modo, os resultados sinalizam que, para um usuário realizar a insulinoterapia de forma eficaz, ele deve autogerenciar o armazenamento e transporte, a técnica de preparo e a técnica de aplicação da insulina - conforme mostra a Figura 5, assim como, os fatores que influenciam negativamente o autogerenciamento do manejo da insulina como o défice de conhecimento/orientação, o preconceito, a falta de prática, a acuidade visual diminuída, a falta de insumos/medicamentos e a indisponibilidade financeira - conforme apresenta a Figura 6.

FIGURA 5: AUTOGERENCIAMENTO DO CUIDADO NO MANEJO DA INSULINA

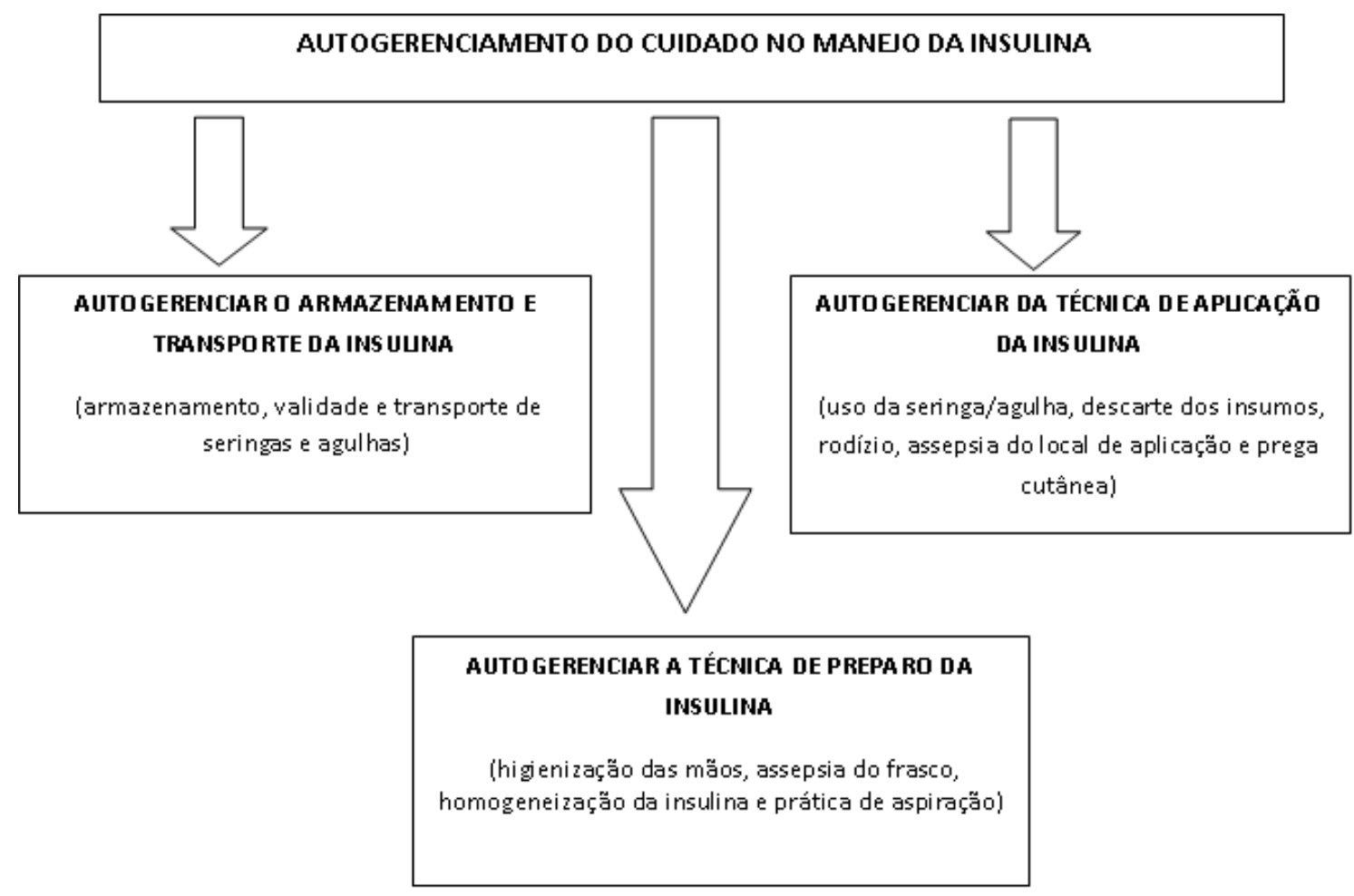


FIGURA 6: FATORES QUE DIFICULTAM O AUTOGERENCIAMENTO DO MANEJO DA INSULINA

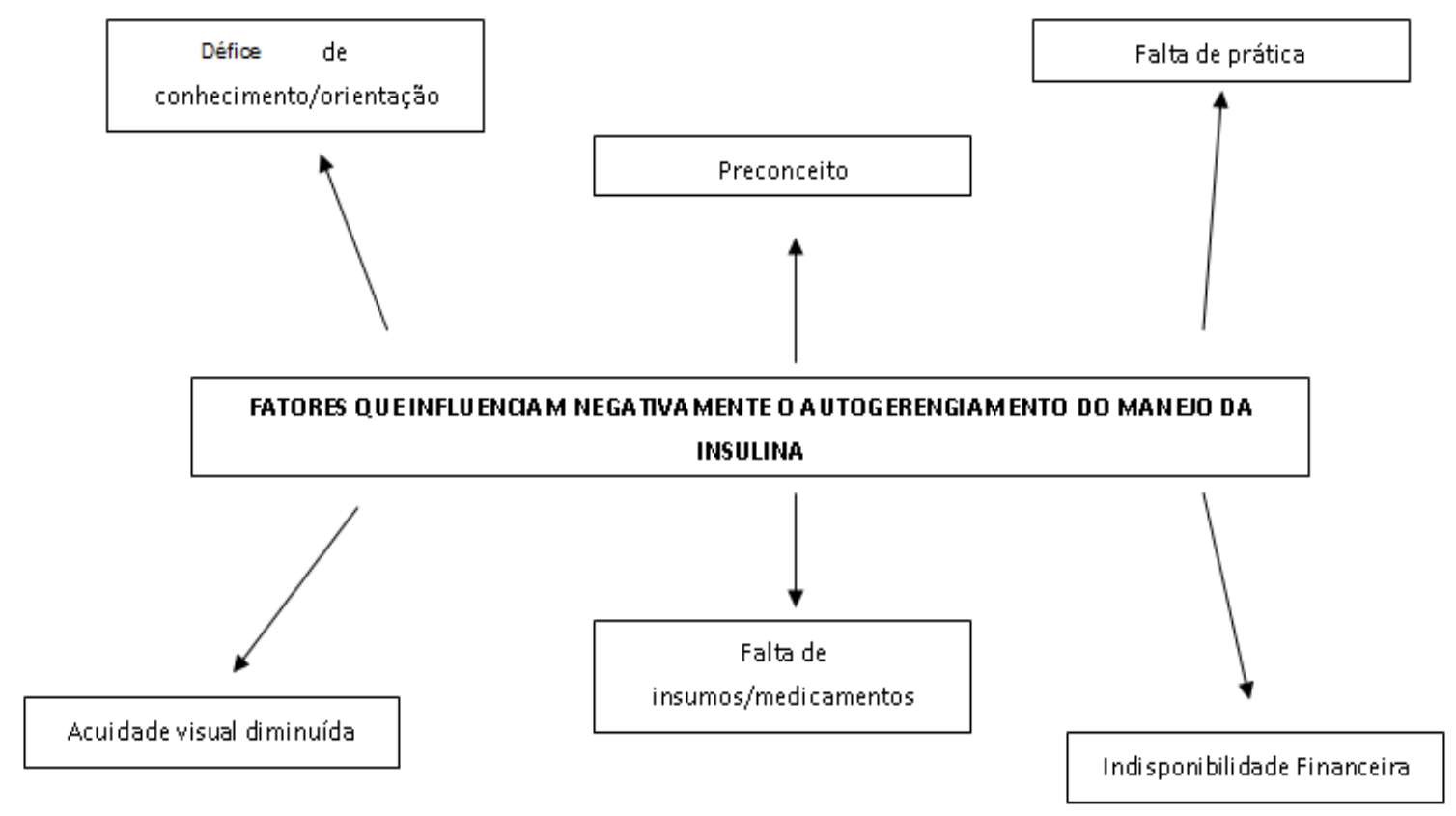




\section{CAPÍTULO 5 - DISCUSSÃO}

Neste capítulo discorreremos os resultados obtidos a partir da análise de dados. Inicialmente, discutiremos a caracterização dos participantes e, posteriormente, as duas categorias que emergiram: a experiência dos insulinotratados em viver com a sua condição crônica e administrar a insulina, e a gestão do cuidado no manejo da insulina.

\section{1 - CARACTERIZAÇÃO DOS PARTICIPANTES}

Nesta pesquisa obtivemos maior participação de usuários do sexo feminino. Tal achado corrobora com os dados obtidos no estudo de prevalência de diabetes e hipertensão no Brasil, baseado em inquérito de morbidade autorreferida, que demonstra que o número de DM é maior entre o sexo feminino (SCHMIDT et al., 2009).

Essa realidade está relacionada justamente com o predomínio do número de usuárias diabéticas atendidas na UBS pesquisada, em que, de 711 usuários portadores de diabetes, 439 são do sexo feminino.

Esse fato reforça também que mulheres procuram mais o serviço de saúde e obtêm o diagnóstico prévio da doença, aspecto esse que possui relação com a concepção de cuidado culturalmente atribuída às mulheres (MOREIRA; GOMES; SANTOS, 2010).

Alguns estudos constataram que mulheres procuram mais os serviços de saúde porque são mais cuidadosas, têm mais paciência, desfrutam de maior disponibilidade, são estimuladas desde pequenas a irem ao médico, e também devido ao seu maior envolvimento com as atividades propostas de autocuidado, como a auto-aplicação de insulina e a prática de atividades físicas (DIÓGENES et al., 2012; FREITAS et al., 2015; ALVES et al., 2011).

Deve-se ressaltar que os homens procuram os serviços de saúde apenas no surgimento de uma doença, fato que contribui com a diminuição da expectativa de vida desses em relação às mulheres (ALVES et al., 2011).

As intensas jornadas de trabalho, a falta de tempo, a inflexão de horários, os aspectos culturais, a organização do serviço de saúde, os fatores socioeconômicos e o desconhecimento da importância da prática preventiva, funcionam como fatores que dificultam a busca dos homens aos serviços de saúde (SILVA et al., 2010; CAVALCANTI et al., 2014). 
Em relação à idade, cinco usuários estavam na faixa etária de 55 a 59 anos, confirmando o que foi relatado por Ramos e Ferreira (2011) em seu estudo sobre fatores emocionais, qualidade de vida e adesão ao tratamento em adultos com diabetes tipo 2.

As doenças crônicas não transmissíveis como o DM têm a característica de acometer as pessoas com o avançar da idade, devido à ocorrência concomitante de vários fatores de risco, uso contínuo de diversos medicamentos e mudanças fisiológicas advindas do processo de envelhecimento (MALTA et al., 2013).

Quanto ao estado civil, igualou-se o número de solteiro com os dos casados. Ao serem comparados os estratos feminino e masculino com o estado conjugal, percebeuse que a maioria das mulheres vivia sem companheiros, já os homens encontravam-se ou casados ou solteiros. Esse perfil está de acordo com os resultados de um estudo realizado por Lima, Pereira e Romano (2011), no qual se verificou que, quanto mais elevada a idade da mulher, maior a sua proporção de viver sem companheiro, quando comparadas a homens da mesma faixa etária.

É importante ressaltar o estado civil dos participantes do estudo, pois a presença de um(a) companheiro(a) pode ajudar na melhoria da gestão do processo de autocuidado, como foi observado ao longo das entrevistas. Uma vez que a organização familiar quando bem orientada pode influenciar diretamente nas adoções de comportamento protetores da saúde no cotidiano da pessoa com diabetes, estimulando a adoção de hábitos saudáveis, como a prática de exercício físico, o seguimento da dieta hipoglicemiante, a realização do controle glicêmico, a prática da autoaplicação da insulina e o autocuidado com o corpo (SANTOS et al., 2011).

No tocante à escolaridade, dos dez usuários, somente quatro possuem o ensino médio completo. A baixa escolaridade pode influenciar diretamente a não adesão ao tratamento devido à dificuldade em entender a prescrição médica, o mecanismo fisiológico da doença e as orientações quanto ao controle da glicemia (RODRIGUES et al., 2012; LYRA et al., 2010).

Dessa forma, faz-se necessário o estudo de estratégias de educação em saúde nos diversos níveis de escolaridade, com a finalidade de aumentar o empoderamento dos usuários em relação à gestão do seu próprio cuidado e adequá-las.

Em relação à ocupação exercida, três eram servidores públicos, dois comerciantes, e os demais aposentado, pensionista, desempregado, cozinheira e açougueiro. 
Quando perguntados sobre a renda familiar, a maioria relatou que a faixa salarial estava entre $R \$ 881,00$ a $R \$ 2.640,00$, dado que diverge do encontrado em vários estudos (ZANDONÁ; OLIVEIRA, 2012; SANTOS et al., 2010), que afirmam que a maioria dos diabéticos possuíam uma renda mensal familiar de um salário mínimo.

Tal achado ratifica os dados obtidos pela Pesquisa Distrital por Amostra de Domicílios - PDAD 2013, realizada em Ceilândia, cuja renda domiciliar média dos moradores dessa Região Administrativa do Distrito Federal era de $R \$ 2.509,00$ (DISTRITO FEDERAL, 2013).

Vale ressaltar que o Distrito Federal (DF) tem a maior renda per capita média de todo país, sendo de $R \$ 2.252,00$ em 2015, mas também possui um dos maiores custos de vida, o que não proporciona benefício direto à população brasiliense (SAMPAIO, 2016).

O fator financeiro é extremamente importante para subsidiar o tratamento dos portadores de DM, pois um estudo realizado nos Estados Unidos afirma que os usuários que possuem instabilidade financeira apresentam dificuldades em realizar o controle glicêmico e a prática do autocuidado (SELIGMAN et al., 2010).

Em relação ao tempo de insulinoterapia, os usuários apresentaram variação de dois a quinze anos, com uma média de 5,6 anos. O tempo de insulinoterapia influencia na segurança, no conhecimento e na prática da administração desse hormônio (STACCIARINI; CAETANO; PACE, 2011). Quanto ao tipo de insulina, a mais utilizada foi a insulina humana Neutral Protamine Hagedon (NPH). Isso aconteceu devido à sua ação intermediária, à longa experiência com seu uso, ao seu menor custo e pelo fato de ela ser a única insulina de ação intermediária disponibilizada pelo Centro de Saúde estudado (BRASIL, 2009; 2013).

Vale ressaltar que, quando os diabéticos necessitam utilizar outro tipo de insulina que não é disponibilizada pelo Centro de Saúde, os mesmos devem procurar as farmácias que dispensam os medicamentos de média complexidade, localizadas em outras regiões administrativas, tais como Hospital de Base, Hospital Universitário de Brasília, Policlínica de Taguatinga e Centro de Saúde nํ 8 do Gama (DISTRITO FEDERAL, 2016). 


\section{2 - A EXPERIÊNCIA DOS INSULINOTRATADOS EM VIVER COM A SUA CONDIÇÃO CRÔNICA E ADMINISTRAR A INSULINA}

Nessa categoria privilegiou-se analisar o conhecimento e experiências vivenciadas pelos usuários em relação ao DM e ao uso da insulina. Para o portador de DM, o conhecimento sobre a sua doença e a prática da insulinoterapia são fatores imprescindíveis para o êxito do tratamento e, consequentemente, para a manutenção do controle metabólico (FERRI, 2013). Em geral, os usuários retratam o período de descoberta da sua condição crônica e da necessidade de uso de insulina como algo estressor e negativo,

\subsection{1 - A experiência dos diabéticos em viver com sua condição crônica}

Correr et al. (2013) acreditam que as emoções ligadas à negação, à minimização da doença, à raiva, à frustração, à depressão, à culpa e à procura de soluções impossíveis para a cura do DM são vivenciadas por todos os usuários ao descobrirem ser portadores dessa patologia. Porém, neste estudo foi possível reconhecer que apenas as emoções ligadas ao medo, ansiedade e depressão foram vivenciadas durante o diagnóstico da doença.

A própria característica da condição crônica do DM, como o seu caráter irreversível, as mudanças no estilo de vida e a dependência contínua de medicamentos levam os usuários com o diagnóstico de DM a possuírem maior probabilidade de vivenciar, de forma patológica, o medo, o estresse, a ansiedade e a depressão (RAMOS; FERREIRA, 2011).

A American Diabetes Association - ADA (2013) preconiza que as variáveis psicológicas devem ser incluídas como uma parte contínua no manejo do diabetes, visto que o medo, a ansiedade e a depressão são fatores que influenciam o seguimento do tratamento e os cuidados com o DM.

Dessa forma, ao diagnosticar sinais e sintomas emocionais, o profissional de saúde precisa fazer intervenções específicas, muitas vezes simples, como a determinação de metas para satisfação com a vida. No entanto, em virtude da formação biologicista dos mesmos, esses aspectos por vezes podem ser identificados, mas não há ações para minimizá-los, assim, restritos à identificação.

Outra alternativa seria o encaminhamento desse indivíduo para profissional de saúde devidamente treinado para ajudar o usuário a lidar com as dificuldades emocionais advindas do DM. Porém, sabe-se que no Centro de Saúde investigado não 
existe um profissional da área de psicologia para realizar esse tipo de assistência; assim, o portador de diabetes precisa ser acompanhado no próprio local, diferentemente da proposta do atendimento na RAS (Vide fluxograma de atendimento ao paciente diabético, p.34), em que diferentes profissionais atendem a esse indivíduo. Dessa forma, as reações emocionais precisam ser bem compreendidas pelos profissionais que atuam na atenção básica, uma vez que muitas vezes manifestam tais reações por meio de comportamentos inadequados que interferem no bom controle glicêmico, o que repercute na saúde, nas relações sociais e, por extensão, na qualidade de vida do usuário.

No entanto, para que ocorra tal acompanhamento, deve haver redefinições nos processos de trabalho dos profissionais. Sendo que essas mudanças poderiam ocorrer desde o momento do diagnóstico de DM, pois esses sentimentos negativos, em geral, são despertados por conceitos preconcebidos ou por desconhecimento sobre essa condição crônica, relacionando essa doença unicamente com a alimentação não saudável, causando culpabilização/vitimização do usuário, ou mesmo por ruídos na comunicação entre profissional e usuários.

Para isso, o indicado é o treinamento das equipes que atendem à pessoa com DM, visto que dentre as atribuições da equipe da APS inclui a de promover a saúde mental do usuário, auxiliando a enfrentar as pressões advindas do DM, respeitando sua individualidade e, consequentemente, seguindo as diretrizes da Política Nacional de Humanização (PHN).

Mediante os resultados apresentados, a maneira com que os usuários reagiram diante da doença interfere diretamente no desempenho dos papéis de autocuidado, cabendo aos profissionais de saúde o papel de mediar a relação emocional e o desempenho das ações de autocuidado, pois os aspectos emocionais dos usuários geram outras demandas para os serviços de saúde, além da hiperglicemia própria da DM.

No tocante à definição de como é viver com o DM, a maioria dos usuários definiram essa experiência como algo negativo, pois o adoecer crônico gera sentimentos de inferioridade, medo, raiva, revolta, frustração, ansiedade e depressão. Porém, somente um indivíduo citou que a falta de conhecimento minimizou os efeitos negativos, pois ele não conhecia a doença e suas possíveis complicações.

Gomes e Espírito Santo (2015) afirmam que, diante do choque do diagnóstico, os usuários apresentam sentimentos negativos como susto, tristeza e medo devido ao entendimento de perceber que as coisas já não são, nem serão mais do mesmo jeito, e 
que agora precisam aprender a conviver com as mudanças físicas, sociais e alimentares.

Foi observado, nos usuários que os sentimentos negativos são vivenciados principalmente devido às dificuldades encontradas no replanejamento da vida diária, como as mudanças de hábitos e estilo de vida, e a adoção e manutenção das restrições dietéticas.

Oliveira e Zanetti (2011) relatam que alguns usuários buscam minimizar os efeitos negativos da doença, utilizando eufemismos, pelo falto de não possuírem conhecimentos acerca da patologia que desenvolveram, porém os participantes deste estudo não utilizaram essa figura de linguagem. Dessa forma, faz se necessário realizar rodas de conversa na UBS para incentivar a troca de experiência, a fim de facilitar a compreensão e as explicações sobre o processo de adoecer com DM.

Em relação à descoberta da $\mathrm{DM}$, os usuários relataram que descobriram a doença ao apresentar os seus sinais e sintomas em casa, e por isso procuraram o serviço de saúde. Um dos critérios para realizar o diagnóstico de DM aceito pela Sociedade Brasileira de Diabetes (2015) é a pessoa apresentar poliúria, polidpsia, perda de peso acrescidos de glicemia casual maior que 200 mg/dl. Para o Ministério da Saúde (BRASIL, 2013), os principais sinais e sintomas característicos do DM são os "quatro Ps": poliúria, polidipsia, polifagia e perda inexplicada de peso.

Observa-se, nas falas dos usuários, que os sinais e sintomas apresentados na hiperglicemia como a perda de peso, a polidpsia e a poliúria facilitaram o diagnóstico da doença, porém a falta de conhecimento e de experiência de alguns profissionais da área de saúde pode levar ao diagnóstico incorreto, como aconteceu com o entrevistado II (p.46), que teve seu diagnóstico confundido com virose.

Outro ponto a se considerar é que todos os usuários tiveram o DM diagnosticado na UBS por meio de exames laboratoriais. Esse é um dos aspectos positivos sobre a gestão de cuidado existente no serviço de saúde pesquisado, que propicia diagnóstico, tratamento e acompanhamento dos portadores de DM.

Porém isso não reflete o acesso ao serviço de saúde, pois, de acordo com o cronograma de marcação de consultas entregue aos usuários, percebe-se que os entrevistados têm somente duas consultas médicas agendadas por ano, e relataram possuir dificuldades em conseguir uma terceira consulta, recorrendo assim, várias vezes ao serviço privado de saúde.

Vale ressaltar que o número de consultas e atendimentos ao usuário com DM deve considerar a estratificação de risco descrita por Brasil (2013). Porém a equipe 
deve ter sensibilidade para considerar os determinantes sociais de saúde, as necessidades individuais e as intercorrências clínicas.

Quando questionados sobre motivos que acreditavam ter desenvolvido DM, os usuários relataram que podem ter adquirido a doença devido ao hábito de vida não saudável. Cabe ressaltar que uma alimentação não saudável é um fator de risco modificável associado ao DM tipo 2, pois afeta a sensibilidade e a secreção de insulina, causando a hiperglicemia (NAGAII; CHUBACI; NERI, 2012). Mas essa não é a única causa, visto que o DM tratar de uma síndrome multifatorial.

Durante as entrevistas, o DM foi diversas vezes comparado com outras doenças como a Aids, problemas cardíacos e o câncer. Essa comparação pode ter acontecido, pois as doenças citadas nas falas acima são doenças graves que requerem tratamento geralmente contínuo, que dificilmente possuem cura e, quando não controladas, podem causar graves complicações como o DM.

Essas comparações precisam ser aclaradas aos usuários, uma vez que tanto os efeitos colaterais/adversos das drogas para tratamento de câncer e Aids, quanto o cotidiano desses indivíduos são mais exigentes, indicando a necessidade de aprofundamento nesse aspecto. Para nortear essa ação, faz-se necessário empoderar os usuários de conhecimentos relacionados à sua condição crônica, esclarecendo que o DM é uma doença crônica, que pode ser controlada e que o correto tratamento evita complicações.

Ainda, os usuários demonstraram ter ciência de que o DM é uma doença crônica incurável, mas alguns acreditam na possibilidade da cura divina. Nos depoimentos, revelaram que a fé e a crença religiosa são mecanismos decisivos para o enfrentamento da doença. Segundo Nagai, Chubaci e Neri (2012), a fé religiosa auxilia no tratamento do DM, pois gera esperança, equilíbrio, fortalecimento, propiciando apoio para lutar pela vida e consequentemente aceitar a doença.

Apesar de a fé ser mecanismo de enfrentamento, ela pode se esgotar e trazer a desistência da terapia, no caso destes, da insulinoterapia. Vale ressaltar também que na literatura existem várias interferências de setores religiosos nas recomendações de profissionais de saúde; em outras palavras, alguns religiosos orientam os usuários a abandonarem o tratamento farmacológico, justificando que a intervenção divina seria capaz de promover a cura milagrosa do diabetes (NETTO, 2016). Dessa forma, os profissionais de saúde devem ficar atentos às manifestações religiosas que prejudicam o tratamento dos portadores de diabetes, a fim de minimizar complicações advindas do abandono da terapia medicamentosa. 
Baquedano et al. (2010) afirmam que quanto maior o tempo de diagnóstico da doença menor é a adesão terapêutica do usuário. Em contrapartida, Arrelias et al. (2015) destacam que aqueles usuários que possuem maior tempo de diagnóstico têm maiores informações sobre a fisiopatologia da doença, tornando-os mais seguros em relação ao tratamento prescrito.

Quanto ao tempo de diagnóstico da doença, os usuários apresentaram uma variação de dois a vinte anos, possuindo uma média de 9,9 anos, contradizendo os dados encontrados na pesquisa de Villas Boas et al. (2012), que destacou-se que o tempo médio de diagnóstico de DM foi de 14,8 anos. Essa divergência pode ter acontecido devido ao critério utilizado para a inclusão do participante da pesquisa, em que foram entrevistados tanto usuários que se encontravam na fase etária adulta como idosos.

O presente estudo mostrou que usuários que possuíam menos de cinco anos de diagnóstico da doença tiveram maior aceitação ao tratamento proposto e a adesão à prática de autocuidado; já aqueles que tinham mais de dez anos de diagnóstico apresentaram comportamentos indesejáveis frente a alguns elementos do autocuidado como a prática de atividade física.

Dessa forma, esse aspecto pode servir como sinal de alerta para a equipe de saúde, como acompanhar as pessoas com DM de modo diferenciado, para além da estratificação de risco; ou seja, observar a adesão dos usuários ao tratamento prescrito e a prática da gestão do cuidado. Ao diagnosticar indivíduos com dificuldades em seguir a terapêutica, é necessário registrar esse achado a fim de alertar a equipe de saúde quanto ao usuário que apresenta maior propensão de desistir de algum aspecto da terapêutica.

Sobre o tipo de diabetes, seis indivíduos não souberam responder com exatidão essa pergunta. É de suma importância que o usuário saiba o tipo de diabetes que possui, pois a evolução clínica e o prognóstico dessa condição crônica modificam de acordo com o tipo de diabetes que o mesmo apresenta. O diagnóstico correto permite traçar estratégias de tratamento para obtenção de um bom controle glicêmico, o que minimiza futuras complicações (CORREIA et al., 2011; MARASCHIN et al., 2010).

Ao analisar a conjectura relacionada com o desconhecimento sobre o tipo de diabetes, percebemos que a vivência no campo e dos relatos, que os usuários já foram orientados sobre essa questão, porém a estratégia de educação em saúde pode não ter sido eficiente, visto que os usuários não conseguiram definir o tipo de diabetes que possuiam. Dessa forma, faz-se necessária uma abordagem mais detalhada desse item 
nas palestras educativas e nas consultas oferecidas na UBS que envolvem enfermeiro, médico, farmacêutico, nutricionista.

As principais dificuldades reveladas pelos usuários relacionadas ao manejo do DM foram: seguir uma dieta hipoglicemiante e praticar atividades físicas. Percebeu-se também que essas dificuldades são vivenciadas por influência do fator econômico e do comodismo.

Todos os usuários demonstraram dificuldade em seguir as restrições impostas pela alimentação. A não adesão a essa prática foi justificada pelo excesso de trabalho, hábitos culturais, a dificuldade em seguir horários pré-estabelecidos e a indisponibilidade financeira. Já a dificuldade em realizar atividade física foi justificada pelo cansaço, comodismo, esforço físico realizado no trabalho, dupla jornada exercida pelas mulheres em casa e no trabalho, indisponibilidade financeira e por complicações nos membros inferiores advindas da doença.

A mudança de hábitos de vida é um processo lento e gradual, particularmente no que se refere à alimentação e à prática de atividade física, pois ambos estão relacionados a hábitos culturais e a disponibilidade financeira dos usuários (SOARES; ARAÚJO; OLIVEIRA, 2014).

A rotina diária que o DM exige é complexa e requer a participação de terceiros, como familiares e amigos, para influenciar positivamente na adesão ao tratamento; porém, os usuários da UBS participantes deste estudo não obtêm apoio adequado de seus amigos, sendo muitas vezes esquecidos por eles e/ou expostos às brincadeiras constrangedoras.

A situação descrita acima pode acentuar o quadro de depressão dos usuários e consequentemente prejudicar a qualidade de vida dos mesmos (SANTOS, 2013). Ainda segundo esse autor, a qualidade de vida está diretamente relacionada ao grau de satisfação familiar, amorosa, social e ambiental.

Dessa forma, é possível afirmar que o ciclo de amizade dos usuários deste estudo dificulta a adesão ao tratamento do DM, contradizendo o que foi exposto por Vilas Boas et al. (2012), que afirmam que a influência de amigos pode levar a maior adesão, tanto nas recomendações de dieta e exercício físico, quanto no tratamento medicamentoso.

Portanto, sugerimos que profissionais de saúde da UBS proporcionem ambientes e atividades que aproximam usuários que vivem com DM em horários distintos, pois essas atividades acontecem somente no período matutino, a fim de garantir a participação de usuários trabalhadores, proporcionando-lhes espaços 
destinados à socialização, ao relaxamento, à promoção do autocuidado, à troca de experiência e, consequentemente, melhorar a qualidade de vida dos usuários.

\subsection{2 - A insulinoterapia na visão de pessoas com diabetes}

Em relação à descoberta da necessidade do uso de insulina, os usuários relataram que vivenciaram alguns sentimentos como medo, raiva, angústia, ansiedade, susto e depressão. Segundo Torquato, Santos e Santa (2015, p. 34), "a raiva, a depressão, o medo da doença, a baixa motivação e o receio de utilizar insulina são sentimentos aflorados na vida de um portador de DM em insulinoterapia".

Percebe-se que os usuários apresentaram diversos sentimentos que dificultam a adesão à insulinoterapia. Acredita-se que esses sentimentos foram vivenciados pelo fato de classificar o diabético insulinodependente como uma pessoa que não obteve êxito no seu tratamento e que precisará utilizar a insulina continuamente.

Batista et al. (2013) explicam que o uso de insulina é relacionado erroneamente com a falta de opção de tratamento, e, geralmente, as complicações crônicas da doença são atribuídas como efeitos colaterais da insulinoterapia.

A partir dos resultados deste estudo, os sentimentos vivenciados pelos usuários entrevistados não interferiram somente no uso ou não da insulina, mas também influenciaram negativamente no seguimento das restrições dietéticas quando vivenciadas a raiva e a ansiedade, e na gestão do cuidado quando os diabéticos encontravam-se depressivos.

A prevalência da associação do diabetes com a ansiedade pode chegar até $40 \%$, e isso é uma condição que afeta diretamente o tratamento do DM, visto que o transtorno da ansiedade correlaciona com a baixa adesão ao tratamento e ao controle glicêmico inadequado (SANTOS, 2013).

Os sentimentos vivenciados pelos usuários de insulina, descritos anteriormente, mostram que os usuários necessitam de assistência para auxiliá-los no enfrentamento e resolução de problemas avivados pelas demandas advindas dessa terapia. Essa assistência pode ser obtida por meio de consultas de enfermagem que ajudam atingir a excelência no cuidado, pois a consulta proporciona a possibilidade de acompanhamento das necessidades fisiológicas, emocionais e sociais dos indivíduos e autorrealização dos cuidados, quando pautada na Teoria de Wanda Horta, facilitando os ajustes clínicos e a intervenções individualizadas, tendo a possibilidade de se fundamentar em outras teorias. 
O uso de insulina diariamente também foi descrito como uma experiência negativa, pois o ato de aplicar a insulina todos os dias incomoda os usuários. Os entrevistados deste estudo demonstraram desejo em se libertar dessa rotina. Esse movimento corrobora com os achados de Ferri (2013, p.46), pois os participantes de sua pesquisa também compartilharam sentimento de incômodo relacionado à obrigatoriedade do uso da medicação injetável diariamente.

Para muitos portadores de DM, a constante necessidade de automonitorização e as aplicações diárias de insulina levam muitas vezes a omissões de doses, devido aos desconfortos e incômodos gerados pelas furadas (SANTOS, 2013).

Oliveira et al. (2000) reconhecem que as canetas de injeção de insulina são mais convenientes, causam menos dor e consequentemente melhoram a qualidade de vida dos usuários. Assim, se as canetas com todos os tipos de insulinas fossem distribuídas pelo Governo do Distrito Federal (GDF) para os usuários, minimizariam os desconfortos decorrentes da dor na aplicação de insulina.

Vale ressaltar que o GDF disponibiliza os refis da insulina garglina e da determir para o usuário que apresentar o receituário médico nas farmácias que dispensam medicamentos de média complexidade, como a Policlínica de Taguatinga, que é a mais próxima da UBS frequentada pelos diabéticos estudados (DISTRITO FEDERAL, 2016).

Outro incomodo relatado pelos usuários do estudo é que, além das fitas para a realização do teste de glicemia, faltam também medicamentos. A dificuldade de acesso aos insumos para o controle e tratamento do DM, associada à falta de recursos financeiros da família, faz com que os usuários utilizem métodos de economia de insumos como a verificação de glicemia em quantidades inferiores ao orientado para esses indivíduos. Esse movimento também pode ter relação com a falta de conhecimento do usuário em relação ao real significado de verificar glicemia, pois o aumento ou a diminuição da taxa glicêmica pode determinar alterações na prescrição de insulina.

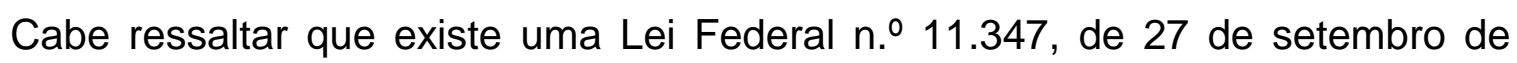
2006, que determina a distribuição gratuita de insumos e medicamentos específicos aos portadores de DM (BRASIL, 2006). Porém os entrevistados deste estudo revelaram que nem todos os usuários acompanhados pela UBS estão assegurados quanto à aquisição de insumos, conforme determina a Lei citada.

Já a Portaria do Ministério da Saúde $n .{ }^{\circ}$ 2.583/2007 considera a automonitorização glicêmica uma ferramenta importante para o controle do DM; assim, 
essa técnica deve ser incluída no plano terapêutico dos usuários, juntamente com os insumos necessários à realização (BRASIL, 2007).

Andrade e Alves (2014) afirmam que a baixa distribuição de insumos e de medicamentos para o tratamento de diabéticos pode estar relacionada ao défice público em decorrência dos gastos incontroláveis no setor saúde e que, para garantir os direitos dos usuários com DM, previsto na legislação, é necessário assegurar o acesso às informações sobre seus direitos legais de cidadãos.

Os usuários relataram que sentem receio em carregar as agulhas e seringas em público. Esse comportamento foi justificado devido ao medo dos entrevistados serem confundidos com usuários de drogas ilícitas injetáveis. Essas falas sinalizaram a existência do risco de sofrer preconceito em relação ao uso de insulina por parte do próprio usuário insulinodependente, e que isso prejudica a liberdade do transporte, manuseio e a aplicação da insulina de forma segura.

Portanto, pode-se perceber que a descoberta da necessidade do uso de insulina potencializa os efeitos emocionais negativos advindos da descoberta dessa condição crônica, prejudicando a adesão ao tratamento e a autogestão do cuidado.

\section{3 - A GESTÃO DO CUIDADO NO MANEJO DA INSULINA}

Nessa categoria será discutida a gestão do cuidado e os diferentes comportamentos revelados por meio de falas e simulações relacionadas ao armazenamento, transporte, preparo e aplicação da insulina.

\subsection{1 - Armazenamento e transporte da insulina}

As insulinas apresentam estabilidade e têm sua ação preservada desde que devidamente conservadas; para tanto, as insulinas lacradas devem ficar refrigeradas entre $2^{\circ} \mathrm{C}$ e $8^{\circ} \mathrm{C}$. Após aberto, o frasco deve ser mantido em temperatura ambiente entre $15^{\circ} \mathrm{C}$ e $30^{\circ} \mathrm{C}$, ou em refrigeração entre $2^{\circ} \mathrm{C}$ e $8^{\circ} \mathrm{C}$ (BRASIL, 2013).

Diógenes et al. (2012) destacam que a insulina necessita de conservação adequada, para que sejam garantidas as suas propriedades farmacológicas, e afirma ainda que o correto armazenamento desse hormônio é na parte inferior da geladeira, não podendo ser armazenada na porta, devido à variação de temperatura nesse local, como também não pode ser congelada ou exposta à luz solar, pois a mesma pode alterar suas propriedades. Caso o usuário não possua geladeira, a insulina deverá ser mantida no local mais fresco do domicílio, por exemplo, próximo ao filtro de água. 
Segundo as Diretrizes da Sociedade Brasileira de Diabetes (2015), a insulina nunca deve ser exposta a temperaturas menores que $2^{\circ} \mathrm{C}$; para tanto, seu armazenamento na geladeira deve evitar locais como a porta, as proximidades com as paredes e com o congelador. Assim, os locais mais indicados para o seu armazenamento são as prateleiras localizadas do meio para baixo e na gaveta de verduras, legumes e frutas.

Vale ressaltar ainda que o Ministério da Saúde (BRASIL, 2013) afirma que a insulina não pode congelar e recomenda-se que o usuário inspecione o seu aspecto antes da aplicação, descartando-a em caso de anormalidades.

Percebe-se que os usuários deste estudo desconhecem a possibilidade de armazenamento da insulina que está em uso à temperatura ambiente, e também não possuem a clareza de qual parte da geladeira é a ideal para manter esse armazenamento. Desse modo, tais aspectos contribuem para o insucesso da terapêutica.

Quando investigado o comportamento dos usuários em relação ao transporte de insulina, eles revelaram que esse medicamento é transportado da UBS para a sua residência dentro de bolsas e sacolas; já o transporte da insulina em caso de viagem é realizado dentro de uma caixa de isopor com gelo.

As Diretrizes da Sociedade Brasileira de Diabetes (2015, p. 222) afirma que:

\begin{abstract}
O transporte da insulina, a fim de manter sua integridade, deve ser cauteloso desde a sua saída da indústria até a chegada ao domicílio, seguindo as devidas recomendações do fabricante e respeitando a temperatura adequada. O transporte doméstico poderá ser em embalagem comum, respeitando-se os cuidados com o tempo, o calor e a luz solar direta. Se utilizada embalagem térmica ou isopor, com gelo ou similar, deve se tomar precauções para que a insulina não entre em contato direto. Sempre transportá-la como bagagem de mãos. Não é recomendado conservá-la em porta-luvas, painel, bagageiro de carro ou ônibus.
\end{abstract}

Já o Ministério da Saúde - MS (BRASIL, 2013) ressalta que, em caso de transporte ou viagem, deve-se colocar a insulina em bolsa térmica ou caixa de isopor sem gelo. $\mathrm{Na}$ ausência de bolsa térmica, o transporte deve ser realizado em bolsa comum, tendo o cuidado em não expor a insulina ao calor excessivo.

Observa-se que existe uma discordância entre o que é recomendado pela SBD (2015) e pelo MS (BRASIL, 2013) em relação ao uso ou não do gelo na caixa de isopor ou na bolsa térmica. Faz-se necessário o desenvolvimento de outras pesquisas com esta temática, a fim de assegurar maiores conhecimentos para que os usuários sejam orientados em relação a melhor maneira de transportar a insulina, garantindo as suas propriedades farmacêuticas. Vale ressaltar também que a insulina, após aberta, não 
pode ultrapassar a 30ㄷ (BRASIL, 2013); contudo, ao realizar o transporte desse medicamento sem gelo, deve-se considerar a temperatura ambiente e o tempo de viagem, pois vários estados brasileiros apresentam temperatura ambiente maior que $30^{\circ} \mathrm{C}$.

Outro ponto importante que foi observado neste estudo é que a maioria dos usuários não se atenta para o prazo de uso da insulina e que utiliza um frasco de insulina por mais de um mês após aberto. O MS (BRASIL, 2013, p. 152) afirma que "após um mês do início do uso, a insulina perde sua potência, especialmente se mantida fora da geladeira. Por isso é importante orientar que o usuário anote a data de abertura no frasco".

De acordo com as Diretrizes da SBD (2015), existe diferença entre a conservação de insulina lacrada e a insulina em uso, conforme quadro abaixo:

QUADRO 1: CONSERVAÇÃO DA INSULINA

\begin{tabular}{l|l|l|}
\hline \multicolumn{1}{c|}{ INSULINA } & \multicolumn{1}{c|}{ TEMPERATURA } & \multicolumn{1}{c|}{ TEMPO DE USO } \\
\hline $\begin{array}{l}\text { Insulina lacrada } \\
\text { Frasco, refil e caneta descartável }\end{array}$ & Sob refrigeração, entre $2^{\circ} \mathrm{C}$ a $8^{\circ} \mathrm{C}$ & $\begin{array}{l}2 \text { a } 3 \text { anos, de acordo com o fabricante, a partir da } \\
\text { data de fabricação }\end{array}$ \\
\hline $\begin{array}{l}\text { Insulina em uso } \\
\text { frasco e caneta descartável }\end{array}$ & $\begin{array}{l}\text { Sob refrigeração, entre } 2^{\circ} \mathrm{C} \text { a } 8^{\circ} \mathrm{C} \\
\text { ou } \\
\text { Até } 30^{\circ} \mathrm{C} \text {, em temperatura ambiente }\end{array}$ & $\begin{array}{l}4 \text { a } 6 \text { semanas após a data de abertura e início do } \\
\text { uso, de acordo com o fabricante }\end{array}$ \\
\hline $\begin{array}{l}\text { Insulina em uso } \\
\text { Caneta recarregável }\end{array}$ & Até $30^{\circ} \mathrm{C}$, em temperatura ambiente & $\begin{array}{l}\text { 4 a } 6 \text { semanas após a data de abertura e início do } \\
\text { uso, de acordo com o fabricante }\end{array}$ \\
\hline
\end{tabular}

FONTE: bulario.net, APUD, Diretrizes da SBD (2015), adaptado

Tal quadro aponta que o tempo de uso da insulina, após aberta, varia de quatro a seis semanas, independentemente se armazenada em temperatura ambiente ou sob refrigeração, entre $2^{\circ} \mathrm{C}$ e $8^{\circ} \mathrm{C}$; após esse período, o frasco deverá ser desprezado, pois a sua potência de ação tende a diminuir com o passar do tempo (ARRAIS; OLIVEIRA, 2016). Importante apontar que esse período é superior ao indicado pelo MS, de quatro semanas (BRASIL, 2013).

Assim, as falas revelaram que não foram orientados sobre o prazo de uso da insulina. Dessa forma, indica-se abordar essa temática nas atividades de práticas de saúde realizadas para esse público, pois a administração de insulina fora do prazo de uso interfere diretamente na eficácia do tratamento. 


\subsection{2 - Técnica de preparo da insulina}

A técnica de preparo da dose de insulina para ser administrada requer alguns cuidados específicos para garantir a eficácia do tratamento do DM; para tanto, no presente estudo foi observada a realização de alguns cuidados nessa etapa, como a higiene das mãos e a homogeneização da insulina.

Para iniciar a preparação da insulina, é necessário primeiramente realizar a higienização e a secagem das mãos (BRASIL, 2013; SBD, 2014-2015). Esse passo é fundamental para proporcionar a segurança necessária quanto à aplicação da insulina, pois remove sujidades, suor, oleosidade, células descamativas e algumas microbiotas da pele (BRASIL, 2007).

Porém, somente um usuário afirmou que realiza a higienização das mãos antes de pegar no frasco de insulina para aspiração. Acredita-se que esse passo não foi realizado por todos os usuários, uma vez que para o usuário essa técnica não foi abordada com ênfase durante as consultas e palestras, sinalizando que os profissionais de saúde da UBS preocupam-se mais em abordar temáticas como alimentação saudável e prática de atividade física, do que a técnica de armazenamento, preparo e aplicação de insulina.

Após a higienização das mãos, faz-se necessário realizar a homogeneização da insulina. Segundo as Diretrizes da SBD (2014-2015), para homogeneizar corretamente as insulinas, recomenda-se movimentar o frasco de dez a vinte vezes; sugere-se, ainda, realizar movimentos suaves, pois a agitação desordenada do frasco pode ocasionar o aparecimento de bolhas de ar que dificultam o preparo da dose de insulina.

Neste estudo, metade dos usuários afirmaram realizar a homogeneização da insulina; porém, na hora de demonstrar como isso poderia ser feito, apenas um usuário realizou conforme as recomendações descritas na SBD (2014-2015).

Após a homogeneização da insulina, deve-se proceder à desinfecção da borracha do frasco de insulina com algodão embebido com álcool a 70\%, a fim de diminuir os riscos de contaminação da insulina e da agulha (SBD, 2014-2015). Porém, nenhum usuário descreveu ou demonstrou que realiza a desinfecção da borracha do frasco de insulina conforme recomendado.

Nas observações realizadas durante as simulações de aspiração de insulina, verificou-se que nenhum dos usuários injetou o ar dentro do frasco para auxiliar na aspiração, e que somente um realizou a aspiração da quantidade correta de insulina sem desperdiçar medicação e sem deixar bolha de ar na seringa. 
Contradizendo os dados do estudo de Batista et al. (2013), que encontrou que $52,63 \%$ das pessoas realizavam a introdução de ar no frasco de insulina para facilitar a aspiração da medicação, e 57, 89\%, após a aspiração da insulina do frasco, realizavam o golpeamento da seringa para a retirada de ar.

Stacciarini, Caetano e Pace (2011) afirmam em seu estudo que a maioria dos usuários preparou a dose diferente da prescrita, tanto para uma maior dosagem quanto para uma menor. No presente estudo, somente um usuário conseguiu simular de forma correta a quantidade exata de insulina prescrita pelo médico.

O motivo utilizado para justificar a dificuldade em preparar exatamente a dosagem prescrita de insulina foi que três dos usuários relataram apresentar dificuldades para visualizar as marcações das unidades existentes nas seringas de $1 \mathrm{~mL}$, disponibilizadas pela UBS para a administração de insulina, confirmando o achado no estudo de Carvalho (2015), em que 33\% dos participantes entre a faixa etária de 22 a 85 anos tiveram resultados de acuidade visual para perto diminuída.

Uma das condições indispensáveis para garantir a correta preparação da dosagem de insulina é possuir uma boa acuidade visual; quando essa deficiência é diagnosticada, faz-se necessária a participação de terceiros para auxiliar os usuários com DM no preparo das doses diárias de insulinas (CARVALHO, 2015).

As dificuldades encontradas nas simulações de administração de insulina repercutem negativamente no tratamento dos usuários, visto que a administração incorreta da dosagem interfere diretamente no controle metabólico dos mesmos. Podem ocorrer complicações advindas da hiperglicemia, quando administrada dosagem de insulina abaixo da recomendada, ou da hipoglicemia, quando são administradas mais unidades de insulina do que a prescrita.

Dessa forma, o profissional enfermeiro e a equipe de saúde precisam atentar para identificar fatores facilitadores e dificultadores apresentados pelos usuários para adquirir novos conhecimentos, antes de orientar a técnica de autoaplicação de insulina. Caso se confirme que o usuário não seja capaz de realizar tal procedimento com segurança, faz-se necessário o envolvimento de algum familiar/amigo para assumir essa função.

Outro ponto a ser observado é que os usuários deste estudo são adultos; assim, indica-se criar grupos específicos de atividades em educação em saúde, pois na UBS as orientações acontecem de forma generalizada, tanto para jovens, adultos e idosos, haja vista que fatores dificultadores podem ser específicos de adultos. 


\subsubsection{Técnica de aplicação da insulina}

Em relação à reutilização da seringa/agulha, foi relatado pelos usuários que no mínimo as mesmas são utilizadas em duas aplicações e no máximo em 14 aplicações. O Ministério da Saúde (MS) indicou, em 2006, a reutilização da agulha por esses usuários por até oito aplicações, desde que sejam respeitadas as orientações sobre armazenamento da insulina; higienização das mãos e do local de aplicação, com a devida proteção da agulha com a capa protetora de plástico; que não possua nenhuma ferida aberta nas mãos ou infecção de pele no local de aplicação; e que tenha destreza manual, ausência de tremores e boa acuidade visual para reencapar a agulha com segurança (BRASIL, 2006).

Essa informação foi reiterada em um documento de 2013, que trata de orientações para assistência à pessoa com diabetes. Nele é afirmado que, apesar de as seringas e agulhas serem descartáveis, podem ser reutilizadas por até oito aplicações pela própria pessoa, desde que não tenham sido contaminadas (BRASIL, 2013).

Nesse sentido, vale ressaltar que os usuários que vivem com diabetes em uso de insulina geralmente não possuem conhecimentos técnicos para reconhecer se o dispositivo utilizado para a aplicação da insulina foi contaminado. Para analisar se os dispositivos utilizados para aplicação de insulina estão contaminados ou não, é necessário realizar uma análise bacteriológica nesses instrumentos (WISNESKY et al., 2014), ou pelo menos ter o entendimento do que é um equipamento contaminado na área da saúde.

No presente estudo, observamos que, além dos usuários não possuírem conhecimentos para reconhecer se um dispositivo tinha sido contaminado ou não, a maioria deles não realizava nem o procedimento mínimo exigido para evitar contaminação dos instrumentais utilizados para insulinoterapia - a higienização das mãos. Dessa forma, percebe-se que os usuários necessitam de maiores informações sobre a importância de higienização das mãos antes de administrar a insulina, a fim de evitar possíveis infecções.

Acredita-se que esse tema não é muito discutido na UBS porque a maioria dos profissionais de saúde atuantes nas atividades educativas trata de temas sobre modificação do estilo de vida do usuário, dando menor ênfase na prática segura da administração da insulina. 
Vale lembrar que a Diretoria da Divisão Nacional de Vigilância Sanitária de Medicamento (DIMED), em sua Portaria $n .^{\circ} 04$ de 1986, proíbe o reprocessamento dos artigos médico-hospitalares de uso único em todo território brasileiro, com o argumento que, quando um artigo médico-hospitalar é reutilizado, ele perde suas características originais e pode desencadear riscos aos usuários, como transmissão de agentes infecciosos (BRASIL, 1986)

Contudo, o que se observa é que pessoas adeptas da prática de reutilização de seringas e agulhas não fazem o reprocessamento proibido pela DIMED, sendo que reutilizam esses materiais sem realizar nenhum tipo de assepsia. Quando o fazem, utilizam álcool para limpeza das agulhas. Esse procedimento retira o lubrificante siliconado das mesmas, agravando ainda mais os problemas dérmicos advindos do seu reuso (STACCIARINI; PACE; IWAMOTO, 2010).

Souza e Zanetti (2000) afirmaram que o reuso de seringas e agulhas para administração de insulina não causa infecções, contradizendo o que afirma DIMED (BRASIL, 1986), pois as insulinas possuem fenol e metacresol, aditivos bacteriostáticos que inibem o crescimento bacteriano, protegendo os usuários diabéticos em insulinoterapia de possíveis infecções.

Entretanto, um estudo desenvolvido no Brasil, em 2014, mostrou que, embora a análise bacteriológica de seringas reutilizadas na insulinoterapia não tenha apresentado um percentual significativo na amostra, o reuso de seringas descartáveis coloca em risco a segurança do usuário (WISNESKY et al., 2014).

Estudos (STACCIARINI; PACE; IWAMOTO, 2010; WISNESKY et al., 2014) pontuam que, ao reutilizar a seringa e a agulha na aplicação de insulina, a pessoa coloca em risco sua segurança, aumentando, assim, as chances de obter lesões cutâneas, hematomas, microtraumas, dermatopatia, xantoma eruptivo e até infecções por Cândida Albicans, Staphylococcus Aureus e Streptococcus Pyogenes. A reutilização da agulha também aumenta a chance desse dispositivo quebrar e ficar inserido na pele, a lubrificação da agulha também é comprometida, tornando as aplicações mais dolorosas (CASTRO; GRAZIANO; GROSSI, 2006).

Outro ponto a ser observado é que a DIMED (BRASIL, 1986) proíbe qualquer prática na reutilização descartável em serviço hospitalar, público ou privado; porém, no Brasil não existe nenhuma legislação vigente que cita esta prática no âmbito doméstico (FEDERAL, 2013).

Os usuários afirmaram que, quando reutilizam as agulhas, eles sentem mais dor; isso pode ser resultante da perda da lubrificação siliconada da agulha. Eles também 
apontam a dor e o sangramento como as principais dificuldades relacionadas ao uso de insulina. A dor advinda da aplicação da insulina pode estar relacionada à temperatura da insulina, à reutilização de agulhas e ou ao local de aplicação da mesma.

As Diretrizes da Sociedade Brasileira de Diabetes (SBD, 2014-2015) ressaltam que o frasco de insulina deve ser retirado da geladeira de 15 a 30 minutos antes da aplicação, para garantir melhor conforto, reduzindo a irritação e a dor local.

Já o local de aplicação da insulina deve ser escolhido em comum acordo entre profissionais de saúde e o usuário do serviço de saúde, pois a aplicação em local inapropriado e falta de realização de rodízio pode causar dores, sangramentos, abscessos, hipertrofia e atrofia da região (GAERTNER et al., 2014).

Durante a realização desta pesquisa, percebeu-se também que os insumos necessários para a realização da insulinoterapia eram fornecidos pelo UBS de forma gratuita, conforme a Lei Federal n. ${ }^{0}$ 11.347/2006 (BRASIL, 2006), porém o quantitativo de seringas/agulhas disponibilizada era em quantidade restrita, cerca de dez a quinze unidades por mês, para cada usuário.

Tal achado corrobora com Castro, Graziano e Grossi (2006), os quais relataram que o fornecimento gratuito de quantitativo ideal de seringas e agulhas necessárias para o uso único, na aplicação de insulina por usuários é irregular, favorecendo, assim, o reuso desses materiais.

Comumente os usuários deste estudo optaram pelo reuso de seringas e agulhas; portanto, não compram insumos, haja vista que o custo do tratamento para controle de glicemia é elevado, pois o usuário precisa de insumos para a insulinoterapia, de alimentação equilibrada de proteínas, vitaminas e carboidratos, além de acompanhamento multiprofissional, que nem sempre é disponibilizado de forma eficaz pelo SUS.

Pesquisa bibliográfica sobre o reuso de seringas e agulhas sinaliza que a prática de reutilização de seringa gera polêmica em nível mundial, pois países como os Estados Unidos, Inglaterra e França praticam o reuso desse material (CASTRO; GRAZIANO; GROSSI, 2006).

Sendo assim, essa prática é comum em países desenvolvidos e em desenvolvimento, como o Brasil; a diferença é a legalização dessa prática, pois, nos Estados Unidos, a Associação Americana de Diabetes admite essa prática, já no Brasil não existe uma autorização legal, por parte da Vigilância Sanitária e da Sociedade 
Brasileira de Diabetes (SBD), para que a população com diabetes em insulinoterapia execute essa prática de forma segura (CASTRO; GRAZIANO; GROSSI, 2006).

Diante dessas controvérsias entre a DIMED (BRASIL, 1986), a SBD (SBD, 2014) e o MS (BRASIL, 2006, 2013), os profissionais de saúde podem não ter segurança para orientar os usuários com diabetes quanto aos riscos e benefícios dessa prática, colocando em risco a segurança do usuário. Assim, essas divergências poderiam ser foco de discussão entre essas instituições para que os profissionais de saúde não infrinjam a portaria da DIMED ou recomendações da SBD e do MS.

Outro ponto importante na insulinoterapia é reduzir os elevados encargos do tratamento à família, à sociedade e ao sistema público de saúde. Apesar da prática de reutilização da seringa e da agulha poder diminuir os gastos do tratamento do diabetes, deve-se levar em conta a relação de custo e benefício para a melhoria da qualidade de vida do usuário (WISNESKY et al., 2014).

Portanto, um dos grandes desafios para os serviços de saúde corresponde à garantia da qualidade do uso seguro da insulinoterapia pelos usuários. Inserido nesse contexto, repercute na reformulação de protocolos orientadores sobre o fornecimento de insumos médicos-hospitalares para a insulinoterapia, com o intuito de direcionar a gestão de saúde dos usuários com DM. Considera-se, também, o gerenciamento de riscos pelo reuso de seringas e agulhas em prol da segurança do usuário, por ser um dos pilares para a recuperação de sua saúde (COSTA et al, 2014; NOBREGA; BEZERRA, 2012; SILVA; SANTANA; PALMEIRA, 2013).

Em relação ao descarte correto das agulhas, observou-se que ainda não é seguido pela metade dos usuários. Frequentemente, os resíduos perfurocortantes produzidos em domicílios não recebem manejo e nem descarte correto, misturando muitas vezes com o lixo doméstico. Assim, precisa adequar orientações para as pessoas com DM, em uso de insulina, sobre não desprezar as agulhas no lixo de sua própria residência, gerando risco à comunidade e ao meio ambiente (SILVA; SANTANA; PALMEIRA, 2013).

Alguns estudos (SOUZA, 2008; TAPIA, 2009) apontam a existência de défice de informação sobre o destino dos materiais perfurocortantes por parte dos usuários, mas nesta pesquisa percebeu-se que os usuários são orientados, porém não colocam em prática as orientações recebidas.

Segundo Brasil (2013), o descarte dos materiais perfurocortantes deve ser realizado em recipientes próprios oferecidos pelas instituições de saúde, ou em 
recipientes rígidos como latas, frasco de achocolatados e de amaciantes. Não é recomendada a utilização de garrafa pet para essa finalidade, devido à sua fragilidade.

Nessa questão, faz-se necessário destacar o papel dos profissionais de saúde atuantes nessa UBS, pois sugerimos que esses profissionais direcionem as intervenções educativas sobre as vulnerabilidades levantadas, a fim de reduzir danos ambientais e problemas de saúde causados pelo manejo incorreto de materiais perfurocortantes.

Destaca-se também que, para um adequado manejo dos resíduos sólidos em domicílio de materiais dos Serviços de Saúde, fazem-se necessários investimentos em ações educativas, com o objetivo de orientar os usuários de insulina sobre a importância de sua ação no descarte correto e seguro desse insumo (ANDRÉ; TAKAYANAGUI, 2015).

Quanto à realização de rodízio, somente três usuários realizavam essa prática. Foi possível observar também que, mesmo realizando o rodízio, uma usuária aplica a insulina em um local não recomendável. Entende-se que os entrevistados não realizam o rodízio devido ao défice de informação e à falta de prática.

A realização de rodízio é um ponto decisivo para o tratamento seguro e eficaz com insulina; entretanto, ele deve ser planejado com o intuito de considerar os números de aplicações, os horários e as atividades físicas realizadas ao longo do dia (SBD, 2014-2015).

Assim, a prática do rodízio pode ser orientada pelos profissionais de saúde utilizando metodologias didáticas, dentre essas, a oficina, pois essa prática auxilia os usuários a administrarem insulina nos locais adequados e consequentemente quebra os medos e mitos relacionados a essa prática.

Sobre o ambiente utilizado para realização da aplicação da insulina, quatro usuários relataram que, quando estão fora de casa e chega o horário de administrar a insulina, os mesmos entram em um sanitário para realizar tal procedimento. Esse fato demonstra que os usuários sentem vergonha em utilizar a insulina na frente de outras pessoas, recorrendo, então, a ambientes isolados e contaminados para a realização dessa prática.

Assim, essa prática compromete a segurança do usuário, uma vez que o mesmo realiza esse procedimento em ambiente totalmente contaminado, colocando a sua saúde em risco, visto que a insulinoterapia é um procedimento invasivo que necessita de técnica asséptica para a sua preparação e administração. 
Em relação à assepsia do local de aplicação com álcool antes da administração da insulina, dois usuários realizavam essa prática. Brasil (2013) recomenda que não é necessário limpar o local de aplicação com álcool; já as Diretrizes da Sociedade Brasileira de Diabetes de 2013-2014 e de 2014-2015 relacionam que a falta de cuidados na assepsia do local pode causar infecções de pele, e recomenda realizar a antissepsia com álcool $70 \%$ no local escolhido para aplicação e esperar secar.

Nas observações realizadas durante as simulações de administração de insulina, observou-se que nenhum usuário realizava a prega cutânea para administrar a medicação e que todos possuíam dificuldades para autoadministrar a insulina nos membros superiores.

A prega cutânea somente deve ser realizada quando as agulhas utilizadas ultrapassam $5 \mathrm{~mm}$ de comprimento ou quando o usuário apresenta pouco tecido subcutâneo (SBD, 2014-2015). No caso dos usuários desse estudo, eles utilizavam as seringas de 100 unidades com a agulha acoplada de $6 \mathrm{~mm}$. Dessa forma, todos os entrevistados precisavam ser orientados a realizarem a prega cutânea para a maior precisão na hora da aplicação, conforme mostra o quadro abaixo:

QUADRO 2: INDICAÇÕES E RECOMENDAÇÕES PARA O USO DAS AGULHAS

\begin{tabular}{|c|c|c|c|c|}
\hline AGULHAS & INDICAÇĀOO & PREGA SUBCUTÂNEA & $\begin{array}{c}\text { ÂNGULO DE INSERÇÃO } \\
\text { DA AGULHA }\end{array}$ & IMPORTANTE \\
\hline $4 \mathrm{~mm}$ & Todas as pessoas & $\begin{array}{l}\text { Dispensável, exceto } \\
\text { para crianças } \\
\text { menores de seis anos }\end{array}$ & $90^{\circ}$ & $\begin{array}{l}\text { Recomenda-se realizar prega } \\
\text { subcutânea em pessoas com } \\
\text { escassez de tecido subcutâneo nos } \\
\text { locais de aplicação }\end{array}$ \\
\hline $5 \mathrm{~mm}$ & Todas as pessoas & $\begin{array}{l}\text { Dispensável, exceto } \\
\text { para crianças } \\
\text { menores de seis anos }\end{array}$ & $90^{\circ}$ & $\begin{array}{l}\text { Recomenda-se realizar prega } \\
\text { subcutânea em pessoas com } \\
\text { escassez de tecido subcutâneo nos } \\
\text { locais de aplicação }\end{array}$ \\
\hline $6 \mathrm{~mm}$ & Todas as pessoas & Indispensável & $\begin{array}{l}90^{\circ} \text { para adultos } \\
45^{\circ} \text { para crianças e } \\
\text { adolescentes }\end{array}$ & $\begin{array}{l}\text { Recomenda-se realizar ângulo de } 45^{\circ} \\
\text { em adultos com escassez de tecido } \\
\text { subcutâneo nos locais de aplicação, } \\
\text { para prevenir risco de aplicação IM }\end{array}$ \\
\hline $8 \mathrm{~mm}$ & $\begin{array}{l}\text { Indicação restrita para } \\
\text { crianças, adolescentes } \\
\text { e adultos com } \\
\text { escassez de tecido } \\
\text { subcutâneo }\end{array}$ & Indispensável & $\begin{array}{l}90^{\circ} \text { ou } 45^{\circ} \text { adultos } \\
45^{\circ} \text { crianças e } \\
\text { adolescentes }\end{array}$ & $\begin{array}{l}\text { Recomenda-se realizar ângulo de } 45^{\circ} \\
\text { em adultos com escassez de tecido } \\
\text { subcutâneo nos locais de aplicação, } \\
\text { devido ao risco de aplicação IM }\end{array}$ \\
\hline $\begin{array}{l}12 \mathrm{~mm}, 12,7 \mathrm{~mm} \\
\text { e } 13 \mathrm{~mm}\end{array}$ & $\begin{array}{l}\text { Indicação restrita para } \\
\text { todas as pessoas }\end{array}$ & Indispensável & $45^{\circ}$ & $\begin{array}{l}\text { Alto risco de aplicação IM para todas } \\
\text { as pessoas }\end{array}$ \\
\hline
\end{tabular}

FONTE: SBD, 2015 
Para nortear a orientação do usuário em realizar a autogestão do cuidado no manejo da insulina, foi elaborado um fluxograma que demonstra que, para um indivíduo realizar a insulinoterapia de forma eficaz, ele precisa autogerenciar o armazenamento e transporte, a técnica de preparo e a técnica de aplicação da insulina.

Neste contexto, o fluxograma é uma ferramenta a ser utilizada pelo enfermeiro na gerência do cuidado no processo da autogestão do manejo da insulina. Por ser uma técncia de representação gráfica que possibilita a descrição clara do fluxo ou sequencia de um processo, ou seja, ela propicia a implementação de ações de cuidado sistematizadas.

Também foi observado que vários fatores influenciam negativamente na autogestão do manejo da insulina como o défice de conhecimento/orientação, o preconceito, a falta de prática, a acuidade visual diminuída, a falta de insumos/medicamentos e a indisponibilidade financeira.

Nota-se que a maioria desses fatores é modificável, exceto a acuidade visual diminuída, que pode ser corrigida. Esses fatores podem ser modificados com a oferta de informações qualificadas e por meio de políticas públicas eficazes.

Vale ressaltar que dispor de informações não é o único aspecto envolvido na complexa relação entre o saber e fazer, uma vez que fatores emocionais também influenciam o tratamento. Somente as experiências de vida adquiridas pelos usuários serão capazes de permitir a incorporação de prática e de hábitos de vida saudáveis no seu cotidiano (PÉRES; FRANCO; SANTOS, 2008).

Assim, para o acompanhamento qualificado dos usuários com DM em insulinoterapia, é interessante municiar os profissionais de saúde de instrumentos que facilitem o levantamento de dificuldades vivenciadas pelos indivíduos, para a realização da prática da insulina.

Ao perceber que não existia nenhum instrumental utilizado pelos profissionais da UBS para essa finalidade, foi elaborado como produto dessa dissertação um checklist das etapas da insulinoterapia, com o intuito de nortear especialmente a consulta de enfermagem e avaliar a habilidade dos usuários em realizar a prática de armazenamento, transporte, preparo e administração desse hormônio (APÊNDICE III).

Para utilizar o referido instrumento, sugiro que o profissional de saúde ofereça insumos para a prática da insulina como seringa, agulha, insulinas e algodão; assim, o usuário terá condições de realizar a simulação de autoadministração de insulina. Dessa forma, o profissional poderá avaliar as etapas de preparação, aplicação e 
armazenamento de forma mais fidedigna, avaliando as dificuldades apresentadas e reforçando os pontos necessários.

O checklist produzido representa o modo de organizar os processos de trabalho, que relacionam entre si a cadeia de produção do trabalho. O eixo condutor do fluxo é o usuário, geralmente sistematizado por uma linha de cuidado, visando diminuir os entraves e gargalos que perpassam o processo da autogestão do manejo da insulina.

Vale ressaltar também que, além de oferecer subsídios para auxiliar os profissionais de saúde, faz-se necessário reorganizar a atenção e a gestão do Sistema Único de Saúde, pois atualmente os serviços oferecidos ao público estudado é fragmentado em programas e ações de práticas clínicas, necessitando assim de uma organização em rede, em que cada serviço e prática devem ser repensados como um componente fundamental da integralidade do cuidado, valorizando a particularidade e necessidade de cada indivíduo.

Para que isso ocorra, precisa-se que a assistência do usuário diabético seja realizado por uma equipe multiprofissional, que trabalhe interligada, com a finalidade de concentrar esforços para identificar estratégias que motivem os usuários a promoverem a gestão do seu cuidado, pois um bom controle metabólico diminui a incidência de complicações e melhora a qualidade de vida dos diabéticos.

Os usuários que autoadministram insulina também precisam ser avaliados continuamente pela equipe de saúde, com atividades práticas que permitam observar, corrigir e verificar as suas aquisições de habilidades. Para tanto, recomenda-se que o profissional enfermeiro realize a educação em saúde com foco no treinamento, podendo aplicar o checklist elaborado neste estudo a partir da visão dos usuários com DM em uso de insulina, o mais precoce possível. Esse instrumento pode ser reaplicado em diferentes momentos para reavaliar se as orientações foram assertivas e realinhar conforme a experiência de cada usuário..

Assim, além de treinamento e orientações coletivas realizadas pelos profissionais nessa UBS, os enfermeiros e demais profissionais precisam considerar as políticas já formuladas, tais como Programa Saúde na Escola e Programa Academia da Saúde, que são espaços que reúnem pessoas de diferentes faixas etárias, para desconstruir ideias preconceituosas sobre ter DM e usar insulina, como também alinhar, entre os profissionais de saúde da UBS, ações para o diagnóstico de DM e a necessidade de uso contínuo de insulina. Essa redefinição de fluxo de informações precisa considerar a gestão local, os recursos humanos, a infraestrutura, os recursos materiais, ou seja, o planejamento desse processo de trabalho. 


\section{CAPÍTULO 6 - CONSIDERAÇÕES FINAIS}

Para refletirmos sobre a finalização desse trabalho, retornamos ao seu início, quando apresentamos nossas inquietações diante das experiências vivenciadas pelos usuários ao descobrir sua condição crônica e realiza o uso de insulina e a vontade de contribuir para além dos cuidados da patologia. Assim, nesse momento, podemos analisar as contribuições geradas por este trabalho.

O estudo em questão nos permitiu conhecer os aspectos socioeconômicos das pessoas entrevistadas, compreender a experiência dos insulinotratados em viver com a sua condição crônica, fazer o uso da insulina e analisar a autogestão do cuidado no seu manejo.

Conforme presumimos, o significado do DM e do uso de insulina é circundado por sentimentos negativos que precisam ser compreendidos e trabalhados pela equipe multidisciplinar responsável pela sua assistência. Os resultados foram esclarecedores no que diz respeito a esse quesito.

Assim, foi possível reconhecer que durante o diagnóstico do DM os usuários vivenciaram o medo, a ansiedade e a depressão. Já durante a descoberta da necessidade do uso de insulina, o medo, a raiva, a angústia, a ansiedade, o susto e a depressão foram os sentimentos vivenciados. Notou-se que a necessidade do uso de insulina potencializou os efeitos emocionais negativos advindos da descoberta do DM.

Percebemos, também, no decorrer da coleta de dados, que a aproximação aos usuários envolve empatia, atenção e ética. Observamos que a UBS é um espaço de credibilidade evidente, pois é nesse ambiente que os usuários se sentem à vontade para falar das suas vivências e experiências.

Entendemos que nessa UBS os profissionais esclarecem dúvidas dos usuários, porém nota-se que se faz necessário mais um movimento, principalmente no que diz respeito ao acompanhamento da prática das etapas da insulinoterapia.

Ao analisar a autogestão do cuidado no manejo da insulina, foram identificadas algumas inadequações no uso da mesma, dentre as quais destaca-se o desconhecimento da maioria dos usuários quanto ao armazenamento, transporte e à prática segura de aplicação desse hormônio. Esse achado repercute no controle glicêmico do diabético e consequentemente nas complicações advindas do DM.

Algumas dificuldades foram reveladas durante o manejo do DM, como seguir uma dieta hipoglicemiante e praticar atividades físicas. Percebeu-se que essas 
dificuldades foram influenciadas pelo fator econômico e pelo comodismo. Já os fatores que influenciam negativamente na autogestão do manejo da insulina foram: o défice de conhecimento/orientação, o preconceito, a falta de prática, a acuidade visual diminuída, a falta de insumos/medicamentos e a indisponibilidade financeira dos usuários.

O estudo demonstrou que a problemática da gestão terapêutica do portador de DM em insulinoterapia não é de responsabilidade somente do usuário, mas perpassa desde o cuidado prestado pelos profissionais de saúde até aos problemas administrativos advindos da gestão do próprio serviço de saúde, como falta de insumos e assistência oferecida de forma fragmentada.

Identificamos, ao longo desta pesquisa, vários aspectos que precisam ser trabalhados a fim de minimizar as complicações advindas do manejo da insulina, dentre eles podemos destacar a necessidade de alinhar a linguagem entre profissionalusuário, assim como ações de abordagens diferenciadas das práticas educativas nos ambientes de promoção a saúde/prevenção de agravos.

Assim, este trabalho pode contribuir para que se amplie o olhar sobre o cuidado prestado aos usuários diabéticos em insulinoterapia. A compreensão da realidade sob a ótica dos usuários pode direcionar treinamentos dos profissionais de saúde, por meio de educação continuada e permanente, com a finalidade de oferecer metodologias diversificadas para uma melhor abordagem na educação em saúde, levando em consideração a especificidade do público estudado.

Outra repercussão é estimular novos estudos para que possa sensibilizar os agentes do processo de trabalho - profissionais, usuários e gestores. Desse modo, a promoção da gestão do cuidado repercute de forma positiva na qualidade de vida do usuário, pois o impacto do DM e do uso de insulina na vida do usuário são marcados pelas emoções recordadas e demonstradas no decorrer da realização do estudo, o que nos sugere que seja uma fase de muitos dilemas.

No âmbito da pesquisa, o nosso amadurecimento se deu no sentido da elucidação do nosso objeto de estudo, que nos forneceu diretrizes para uma abordagem metodológica mais apropriada. Mesmo não tendo, até o início da investigação, familiaridade com a pesquisa qualitativa, observamos que o objeto deste estudo nos impulsionou em tal direção. A oportunidade de mudança foi um desafio, superado à medida que nos aproximamos da literatura sobre essa temática. A pesquisa qualitativa nos proporcionou conhecer a subjetividade dos usuários para uma melhor 
abordagem de suas impressões, sentimentos, conhecimentos, vivências, seu cotidiano e dilemas.

Este estudo de compreensão da experiência pode auxiliar a reorganização da atenção ao diabético em nível de APS, com vistas a propor intervenções eficazes e dirigidas de forma a minimizar a morbimortalidade, oferecendo melhor qualidade de vida aos usuários.

Assim, sugerimos o aperfeiçoamento dos programas educativos na UBS, com vistas à promoção da saúde por meio da implementação de atividade física; proporcionar atividades culturais e recreação, visando redução dos sentimentos negativos advindos da descoberta do DM e da necessidade de uso da insulina; oferecer cursos sobre fatores de risco, sintomas do DM e sobre a prática da insulinoterapia para os usuários que necessitam utilizar esse hormônio; e criar materiais educativos para subsidiar a prática correta de transporte, armazenamento, preparo e administração da insulina.

Percebemos também a necessidade de novos estudos, a fim de validarem 0 instrumento de checklist elaborado por esta pesquisa, com a finalidade de nortear a consulta de enfermagem e avaliar o desempenho dos usuários no armazenamento, transporte, preparo e administração da insulina. Vale reforçar que estudos na atenção primária que destaquem a autogestão de pessoas com diabetes são profícuos para diminuir internações de condição sensível, desde que possibilitem apontar manejo adequado e acompanhamento necessário.

Dessa forma, os resultados obtidos apontam para a relevância de se refletir sobre o saber e o fazer no cuidado em saúde quanto ao significado do usuário com DM em insulinoterapia. A perspectiva é não apenas diminuir estatísticas de DM, mas também de sermos capazes de reduzir as complicações advindas do DM, com profissionais mais sensibilizados, que conhecem os sentimentos de seus usuários.

A partir dos resultados, o atendimento à pessoa com diabetes em uso de insulina pode ter diferentes estratégias de abordagem, com a inclusão do checklist, pois, nos mostraram o melhor caminho para uma assistência com qualidade. Sentimonos também realizadas por tê-lo desenvolvido, considerando que seus resultados mostram-se consistentes o suficiente para responder às questões inicialmente propostas aos seus pressupostos atingindo também os objetivos.

Assim, compartilhamos este material para que possa servir como subsídio a mudanças e também como possibilidade a mais de espaço para o trabalho do enfermeiro(a). Que ele sirva de sensibilização da enfermagem, no sentido de perceber 
o usuário diabético além de sua condição crônica, mas como um ser cheio de emoções e sentimentos.

Portanto, entendemos que as ideias aqui expostas não são finais, mas considerações para se pensar no redimensionamento da atenção à saúde do usuário com DM, no propósito de, somando-se às experiências aqui relatadas, trazer novas dimensões para o cuidar, que vão além do aspecto biológico do ser portador da doença, porquanto envolvem a integração das dimensões biológicas e psicossociais incluindo os contextos sociais e culturais desses sujeitos. 


\section{REFERÊNCIAS}

ADA. American Diabetes Association. Diagnosis and classification of diabetes mellitus. Diabetes Care. V. 36 Jan. 2013. Disponível em: < http://care.diabetesjournals.org/content/36/Supplement_1/S67>. Acesso em: 10 mar. 2016.

ALFRADIQUE, M.A et al. Internações por condições sensíveis à atenção primária: a construção da lista brasileira como ferramenta para medir o desempenho do sistema de saúde (Projeto ICSAP-Brasil). Cadernos de Saúde Pública, Rio de Janeiro, v.25, n. 6, 2009. Disponível em: <http://www.scielo.br/pdf/csp/v25n6/16.pdf>. Acesso em: 10 nov.2015.

ALVES, R.F et al . Gênero e saúde: o cuidar do homem em debate. Psicol. teor. prat., São Paulo , v. 13, n. 3, p. 152-166, dez. 2011 . Disponível em: <http://pepsic.bvsalud.org/scielo.php?script=sci_arttext\&pid 36872011000300012\&lng=pt\&nrm=iso>. Acesso em: 06 mar. 2016. $=$ S1516 -

ANDRADE, C.J.N; ALVES, C.A.D. Análise comparativa do controle glicêmico de crianças com diabetes melito tipo $1 \mathrm{com}$ base na distribuição de insumos: capital $x$ interior da Bahia. Rev. Ciênc. Méd. v. 13, n.3 - especial, p. 274-279. set-dez, 2014. Disponível em: < http://www.portalseer.ufba.br/index.php/cmbio/article/view/12930>. Acesso em: 15 mar. 2016.

ANDRÉ, S.C.S, TAKAYANAGUI, A.M.M. Orientações sobre o descarte de resíduos gerados em domicílios de usuários de insulina. Revista Baiana de Saúde Pública. V. 39, n. 1, p. 105-118. Março de 2015. Disponível em: DOI: 10.5327/Z0100-02332015390100010. Acesso em: 09 abr. 2015.

ARRAIS E.C, OLIVEIRA, B.F.S. Acondicionamento da insulina no domicílio por diabéticos. Revista Recien, v. 6, São Paulo, n.16, p-21-31, 2016. Disponível em: < http://www.recien.com.br/online/index.php/Recien/article/view/132>. Acesso em: 16 mar. 2016.

ARRELIAS, C.C.A. et al . Adesão ao tratamento do diabetes mellitus e variáveis sociodemográficas, clínicas e de controle metabólico. Acta paul. enferm., São Paulo, v. 28, n. 4, p. 315-322, Ago. 2015 . Disponível em: <http://dx.doi.org/10.1590/19820194201500054>. Acesso em: 12 mar. 2016.

ASSIS L.C, SIMÕES M.O.S, CAVALCANTI A.L. Políticas públicas para o monitoramento de hipertensos e diabéticos na atenção básica, Brasil. Rev. Bras. Pesqui Saude [internet].v. 14, n. 2, p 65-70, 2012. Disponível em: <http://periodicos. ufes.br/RBPS/article/viewFile/4189/3313>. Acesso em: 15 nov. 2014.

BAQUEDANO, I.R. et al. Fatores relacionados ao autocuidado de pessoas com diabetes mellitus atendidas em serviço de urgência no México. Revista da Escola de Enfermagem da USP, v. 44, n. 4, p. 1017-1023, 2010. Disponível em: <http://dx.doi.org/10.1590/S0080-62342010000400023>. Acesso em: 13 mar. 2016.

BARDIN, L. Análise de Conteúdo. Lisboa: Edições 70, LDA, 2009. 
BASTOS, F.S. A pessoa com doença crônica: uma teoria explicativa sobre a problemática da gestão da doença e do regime terapêutico. 2012. 707f. Tese (Doutorado em Enfermagem) - Universidade Católica Portuguesa, Instituto de Ciências da Saúde- Portugal-Porto.

BATISTA J.M.F et al. O ensino em grupo do processo de aplicação de insulina. Rev. Eletr. Enf. v. 15, n. 1, p.71-9, jan, 2013. Disponível em: < http://www.fen.ufg.br/revista/v15/n1/pdf/v15n1a08.pdf. Acesso em: 19 nov. 2015.

BATISTA, N.N.L; LUZ, M.H.B.A. Vivências de pessoas com diabetes e amputação de membros. Rev. Bras. Enfer, Brasília, v.65, n.2, p- 244-50, mar-abr. 2012. Disponível em: http://www.scielo.br/scielo.php?script=sci_arttext\&pid=S0034-71672012000200 007. Acesso em: 13 nov. 2015.

BOAS, L.C.G.V.et al . Adesão à dieta e ao exercício físico das pessoas com diabetes mellitus. Texto contexto - enferm., Florianópolis , v. 20, n. 2, p. 272-279, June 2011. Disponível em: <http://dx.doi.org/10.1590/S0104-07072011000200008>. Acesso em: 12 mar. 2016.

BONDIA, J.L. Notas sobre a experiência e o saber de experiência. Revista Brasileira de Educação. $\mathrm{n}$ 19. Jan/Fev/Mar/Abr, Barcelona, 2002. Disponível em: < http://www.scielo.br/pdf/rbedu/n19/n19a02.pdf>. Acesso em: 20 nov. 2015.

BONIFÁCIO N.A et al. Processo de administração de insulina subcutânea em pacientes diabéticos hospitalizados. Ciênc. Cuidado Saúde, Maringá: 2008. Disponível em: < http://www.periodicos.uem.br/ojs/index.php/CiencCuidSaude /article/view/4996/3238>. Acesso em: 06 dez. de 2015.

BRASIL. Agência Nacional de Vigilância Sanitária. Higienização das mãos em serviços de saúde. Brasília: ANVISA, 2007.

Decreto n. 037.057 de 14 de janeiro de 2016. Dispõe sobre a estrutura administrativa da Secretaria de Estado de Saúde do Distrito Federal. Diário Oficial da União, Brasília, DF, 14 de jan. 2016. Disponível em: < http://www.jusbrasil.com.br/diarios/107131345/dodf-secao-01-15-01-2016-pg-1>. Acesso em: 20 jun. de 2016.

- Lei $n$. ${ }^{11.347}$, de 27 de setembro de 2006. Dispõe sobre a distribuição gratuita de medicamentos e materiais necessários à sua aplicação e à monitoração da glicemia capilar aos portadores de diabetes inscritos em programas de educação para diabéticos [legislação na Internet]. Diário Oficial da União. Brasília; 2006. Disponível em: http://www.planalto.gov.br/ccivil_03 /_Ato2004-2006/2006/Lei/L11347.htm. Acesso em: 20 mar. 2016.

Ministério da Saúde. Caderno de Atenção Básica n. 16: Diabetes Mellitus. Brasília: Ministério da Saúde, 2006. Disponível em: < http://bvsms.saude.gov.br/bvs/publicacoes/diabetes_mellitus.PDF>. Acesso em: 01 set 2015.

Ministério da Saúde. Divisão Nacional de Vigilância Sanitária de Medicamentos. Portaria n. 4, de 7 de fevereiro de 1986. Diário Oficial da União, Brasília, 12 de fev. 1986. Seção 1, p. 23-7. 
Ministério da Saúde. Parecer Técnico-Científico: 0 uso de Insulinas Recombinantes Análogas à Humana de Ação Basal (Glargina e Detemir) no tratamento do Diabetes Mellitus Tipo 1. Brasília - DF. Fev. 2009.

. Ministério da Saúde. Relatório de Recomendação da Comissão Nacional de Incorporação de Tecnologias no SUS - CONITEC. Brasília - DF. Dez. 2013. Disponível em: <http://u.saude.gov.br/images/pdf/2014/fevereiro/28/ RelatorioInsulinas-analogas-diabetes-tipo-I-CP-114.pdf>. Acesso em: 13 mar. 2016.

Ministério da Saúde. Secretaria de Atenção à Saúde. Departamento de Atenção Básica. Estratégias para o cuidado da pessoa com doença crônica: diabetes mellitus. Brasília: Ministério da Saúde, 2013. 160p. (Caderno de Atenção Básica, n. 36). Disponível em: <http://bvsms.saude.gov.br/bvs/publicacoes /estrategias_cuidado_pessoa_diabetes_mellitus_cab36.pdf>. Acesso em: 13 mar. 2016.

Ministério da Saúde. Secretaria de Atenção à Saúde. Departamento de Atenção Básica. Estratégias para o cuidado da pessoa com doença crônica: Diabetes Mellitus. Brasília: Ministério da Saúde, 2013.

. Portaria n.․ 2.583 de 10 de outubro de 2007. Define elenco de medicamentos e insumos disponibilizados pelo Sistema Único de Saúde, nos termos da Lei n.. 11.347, de 2006, aos usuários portadores de diabetes mellitus. Ministério da Saúde, Diário Oficial da União, Brasília, DF, 10 out. 2007. Disponível em: < http://bvsms.saude.gov.br/bvs/saudelegis/gm/2007/prt2583_10_10_2007.html>. Acesso em: 10 nov. 2015.

. Resolução n.- 466 de dezembro de 2012. Incorpora sob a ótica do indivíduo e das coletividades, referenciais da bioética, tais como, autonomia, não maleficência, beneficência, justiça e equidade, dentre outros, e visa a assegurar os direitos e deveres que dizem respeito aos participantes da pesquisa, a comunidade científica e ao Estado. Conselho Nacional de Saúde, Diário Oficial da União, Brasília, DF, 12 dez. 2012. Disponível em: < http://sintse.tse.jus.br/documentos/2013/Jun/13/cns-resolucao-no-466de-12-de-dezembro-de-2012>. Acesso em: 10 nov. 2015.

CARVALHO, G.C.N. Avaliação da acuidade visual para perto das pessoas que preparam doses de insulina. 2015. 115f. Dissertação (Mestrado em Enfermagem)Universidade Federal do Ceará- Fortaleza-Ceará.

CASTRO A.R.V, GRAZIANO K.U, GROSSI S.A. Alterações nos locais de aplicação de insulina e nas seringas reutilizadas pelos pacientes diabéticos. Rev Gaúcha Enferm. Porto Alegre (RS), v. 27, n. 1, p-27-34, 2006. Disponível em: < http://seer.ufrgs.br/RevistaGauchadeEnfermagem /article/view/4581>. Acesso em: 15 out. 2015.

CAVALCANTI, J.R.D. et al . Assistência Integral a Saúde do Homem: necessidades, obstáculos e estratégias de enfrentamento. Esc. Anna Nery, Rio de Janeiro, v. 18, n. 4, p. 628-634, Dez. 2014 . Disponível em: <http://dx.doi.org/10.5935/14148145.20140089. Acesso em: 06 mar. 2016.

CHAVES, M.O; TEIXEIRA, M.R.F; SILVA, S.E.D. Percepções de portadores de diabetes sobre a doença: contribuições da Enfermagem. Rev. Bras Enferm. Brasília v. 
66, n.2, p. 215-21. 2013. Disponível em: < http://www.scielo.br/scielo.php?script=sci _arttext\&pid=S0034-71672013000200010 >. Acesso em: 10 nov. 2015.

CONASS, Conselho Nacional de Secretários de Saúde. CONASS Debate: Inovação na Atenção Ambulatorial Especializada. Revista do Conselho Nacional de Secretários de Saúde. Brasília. Ano. 5, n. 16, jul-ago-set, 2015. Disponível em: < http://www.conass.org.br/biblioteca/pdf/revistaconsensus_16.pdf>. Acesso em: 15 de set. 2015.

CORREIA, F. et al. Diabetes Monogénica: a importância do Diagnóstico molecular. Rev. Port. Endo. Diab. Met. Portugal. p. 64-68. 2011. Disponível: http://www.spedm.org/media/Casos_clinicos-Artigo-4-SPEDM_Vol-6_numero220121110-210323.pdf. Acesso em: 12 mar. 2016.

CORRER, R. et al. Avaliação do cotidiano e enfrentamento de adolescentes com diabetes mellitus 1. SALUSVITA, Bauru, v. 32, n. 3, p. 243-263, 2013. Disponível: http://www.usc.br/biblioteca/salusvita/salusvita_v32_n3_2013_art_03.pdf. Acesso em: 10 nov. 2015.

COSTA G.J.E, LITWAK L.E, FUENTE G.V, FAINGOLD M.C. Adherencia terapéutica y flexibilidad en el uso de las insulinas basales. Medicina (B. Aires) [online]. 2014, vol.74, n.4, p. 273-281.ISSN 0025-7680. Disponível em: < http://bibliomedicinadigital.fmed.uba.ar/medicina/cgi-bin/library.cgi?a=d\&c= catalogo\&d=CatalogoRevar_43721>. Acesso 15: nov. 2015.

COSTA, D.A.M; ZAGO, M.M.F, MEDEIROS M. Experiência da adesão ao tratamento entre mulheres com Vírus da Imunodeficiência Humana/Síndrome da Imunodeficiência Adquirida. Acta Paul Enferm. 2009, v.22. n. 3. p.631-7. Disponível em: < file:///C:/Users/Sandro/Downloads/Experi\%C3\%AAncia\%20da\%20ades\%C3\%A30\%20 ao\%20tratamento.pdf>. Acesso em 20: mar. de 2016.

DAMIÃO, E.B.C. et al., Inventário de estratégias de enfrentamento: um referencial teórico. Rev. Esc. Enferm USP; v. 43, esp 2, p-1199-203, 2009. Disponível em: <http://www.scielo.br/pdf/reeusp/v43nspe 2/a09v43s2.pdf>. Acesso em: 10 nov. 2015.

DIÓGENES, M. et al. Insulinoterapia: conhecimento e práticas utilizadas por portadores de diabetes mellitus tipo 2 [Insulintherapy: knowledgeandpracticesusedbypatientswithtype 2 diabetes mellitus]. Revista Enfermagem UERJ, Rio de Janeiro, V. 20, mai. 2012. Disponível em: <http://www.epublicacoes.uerj.br/ojs/index.php/enfermagemuerj/article/view/ 5998>. Acesso em: 06 mar. 2016.

DISTRITO FEDERAL, Companhia de Planejamento do Distrito Federal. Pesquisa Distrital Por Amostra de Domicílios PDAD-2013 Ceilândia. Brasília, 2013. Disponível em: <http://www.codeplan.df.gov.br/images/CODEPLAN/PDF/Pesquisas \%20Socioeconômicas/PDAD/2013/Ceilândia-PDAD\%202013.pdf>. Acesso em: 05 dez. 2015.

Secretaria de Estado de Saúde do. Unidades de Saúde Vinculadas. Regional de Saúde de Ceilândia. Governo do Distrito Federal, 2015. Disponível em: $<$ http://www.saude.df.gov.br/sobre-a-secretaria/hospitais-e-regionais/266-regional-desaude-de-ceilandia.html> Acesso em: 05 dez. 2015. Acesso: 20 de abril 2016. 
Secretaria de Estado de Saúde. Subsecretaria de Atenção Integral à Saúde. Coordenação de Atenção Especializada à saúde. Diretoria de Assistência Farmacêutica. Relação de Medicamentos Padronizados na SES/DF Média Complexidade. Brasília, 2016. Disponível em: <http://www.saude.df.gov.br/images/DIASF/7_Medicamentos_de_media_complexidad e_padronizados_na_SES_DF.pdf>. Acesso em: 24 mar. 2016.

FARIA A.P.S, BELLATO R. A compreensão do fenômeno condição crônica por diabetes mellitus a partir da experiência de adoecimento. Rev. Eletr. Enf. [Internet]. v.12, n.3, p.520-7, 2010. Disponível em: <http://dx.doi.org/10.5216/ree.v12i3.6953>. Acesso em: 10 out. 2015.

FEDERAL, Ministério Público. Ação Civil Pública. Processo n.o 32214-62. 2013. Disponível em: http://www.prpa.mpf.mp.br/news/2013/arquivos/Decisao_ nacional_seringas_diabetes.pdf. Acesso em: 12 abr. 2015.

FERRAZ, R.R.N. et al., Gestão dos cuidados primários a portadores de diabetes mellitus e insuficiência renal em unidades básicas de saúde. Rev. Eletrônica Gestão \& Saúde. v. 06, n. 1,p. 308-22, 2015. Disponível em: <http://gestaoesaude.unb.br/index.php/gestaoesaude /article/view/798>. Acesso em: 04 jan. 2016.

FERREIRA, A.O.P. et al. Perfil Epidemiológico de Clientes com Hipertensão arterial Sistêmica e Diabetes Mellitus: Evidências para o ensino do autocuidado. Objetiva: Revista do Instituto de Ensino Superior de Rio Verde. p. 43 - 55. ano 6, n. 6 (Jul/dez.2010) - Rio Verde: IESRIVER, 2010.

FERREIRA, D.S.P. et al. Repercussão emocional diante do diagnóstico de Diabetes Mellitus tipo 2. Rev. enferm. UERJ, Rio de Janeiro, v. 21, n.1, p 41-46. jan/mar. 2013. Disponível em: <http://www.facenf.uerj.br/v21n1/v21n1a07.pdf>. Acesso em: 29 mar. 2016.

FERRI, L.P. O processo do autocuidado dos portadores de diabetes mellitus tipo 2 de Jataí/GO [manuscrito]. Dissertação de Mestrado. Universidade Federal de Goiás, 2013. Disponível em: < http://repositorio.bc.ufg.br/tede/bitstream/tede/3519/5 /Disserta\%C3\%A7\%C3\%A30\%20-\%20Lucila\%20Pessuti\%20Ferri\%20-\%202013.pdf>. Acesso em: 30 mar. 2016.

FILHO, C.V.S; RODRIGUES, W.H.C; SANTOS, R.B. Papéis de autocuidado-subsídios para enfermagem diante das reações emocionais dos portadores de diabetes mellitus. Esc. Anna Nery rev Enferm. v.12, n. 1, p-125-9, mar, 2008. Disponível em: <http://www.scielo.br/pdf/ean/v12n1/v12n1a19>. Acesso em: 02 jan. 2016.

FLICK, Uwe. Desenho da pesquisa qualitativa: Coleção Pesquisa Qualitativa. ARTMED EDITORA S. A. Porto Alegre, 2009.

FONTANELLA, B.J.B.; RICAS, J; TURATO, E.R. Amostragem por saturação em pesquisas qualitativas em saúde: contribuições teóricas. Caderno de Saúde Pública, Rio de Janeiro, v.24, n.1, p. 17-27, jan. 2008. Disponível em: < 
http://www.scielo.br/scielo.php?script=sci_arttext\&pid=S0102-311X2008000100 003 >. Acesso em: 02 jan. 2016.

FRAGOSO, L.V.C et al., Vivências cotidianas de adolescentes com diabetes mellitus tipo 1. Texto Contexto Enferm. v. 19. n. 3. p- 443-51, jul-set, 2010. Disponível em:< http://www.scielo.br/pdf/tce/v19n3/a05v19n3. Acesso em: 14 nov. 2015.

FREITAS, E.F. et al . Prevalência de Diabetes Mellitus e Prática de Exercício em Indivíduos que Procuraram Atendimento na Estratégia Saúde da Família de Viçosa/MG.Rev. educ. fis. UEM, Maringá, v. 26, n. 4, p. 549-556, Dez. 2015 .Disponível em: <http://dx.doi.org/10.4025/reveducfis.v26i4.25202>. Acesso em: 09 mar. 2016.

GAERTNER et al. Procedimentos relacionados ao uso de insulina por portadores de diabetes mellitus tipo I e tipo II. Rev. Contexto Saúde. 2014 Jul-Dez: 44-53. Disponível em: $\quad<$ https://www.revistas.unijui.edu.br/index.php/contextoesaude/article /view/2891/3566>. Acesso em: 06 dez. 2015.

GOMES, D.M; ESPÍRITO SANTO, P.S.M.F. Experiências e percepções dos adolescentes com Diabetes Mellitus tipo 1. Rev. Enferm. UFPE online, Recife, 9 (2): 582-91, fev., 2015. Disponível em: DOI: 10.5205/reuol.7028-60723-1-SM.0902201513. Acesso em: 11 mai. 2016.

GRILLO M. F.F et al. Efeito de diferentes modalidades de educação para o autocuidado a pacientes com diabetes. Rev. Assoc. Med. Bras. São Paulo. v. 59, n.4. p-400-405. Jul/Ago. 2013. Disponível em: <http://www.scielo.br/scielo.php?pid=S010442302013000400021\&script $=$ sci arttext>. Acesso em: 12 set. 2015.

GUZ, Gabriela. O consentimento Livre e Esclarecido na Jurisprudência dos Tribunais Brasileiros. Revista de Direito Sanitário, São Paulo, v.11, n.1, p.95-122 Mar/Jun. 2010. Disponível em: <http://www.revistas.usp.br/rdisan/article/view/13197. Acesso em: 16 nov. 2015.

IDF, International Diabetes Federation, Diabetes Atlas 6th- Edition 2013 Update. Disponível em: <http://www.idf.org/sites/default/files/EN_6E_Atlas_Full_0 .pdf>. Acesso em: 6 jun. 2015.

KATZUNG, B.G. Farmacologia. Hormônios pancreáticos e fármacos antidiabéticos. Vol. único, 9 edição, p. 579-597, 2003.

LACERDA, M.R. Cuidado domiciliar: em busca da autonomia do indivíduo e da família na perspectiva da área pública. Ciência \& Saúde Coletiva. Rio de Janeiro, v.15, n. 5, Ago.2010. Disponível em: < http://www.scielo.br/scielo.php?script=sci_arttext\&pid= S1413-81232010000500 036. Acesso em: 06 jan. 2016.

LIMA, A.P, PEREIRA, D.A.G, ROMANO, V.F. Perfil Sócio-Demográfico e de Saúde de Idosos Diabéticos Atendidos na Atenção Primária. Rev. Bras. Ci. Saúde. Minas Gerais. V. 15, n. 1, p. 39-46, jan.2011. Disponível em: <http://dx.doi.org/10.4034/RBCS.2011. 15.01.06. Acesso em: 11 mar. 2016.

LORENZETTI, Jorge et al. Gestão em Saúde no Brasil: Diálogo com Gestores Públicos e Privados. Texto Contexto- Enferm. Vol. 23, oㅡ 2. Florianópolis. Abri/Jun, 2014. 
Disponível em: http://dx.doi.org/10.1590/0104-07072014000290013. Acesso em: 21 abr. 2016.

LYRA, Ruy et al . Prevalência de diabetes melito e fatores associados em população urbana adulta de baixa escolaridade e renda do sertão nordestino brasileiro. Arq Bras Endocrinol Metab, São Paulo, v. 54, n. 6, p. 560-566, Ago. 2010. Disponível em: <http://dx.doi.org/10.1590/S0004-27302010000600009>. Acesso em: 09 mar. 2016.

MAGGINI M. IGEA - A chronic disease management project for people with diabetes. Ann Ist Super Sanitá [Internet]. Roma. v.45, n.4, Out/Dez, 2009. Disponível em: < http://www.scielosp.org/scielo.php?script=sci_arttext\&pid=S0021-2571200900040000 1> . Acesso em: 20 dez. 2015.

MALTA, D.C. et al . Prevalência de fatores de risco e proteção para doenças crônicas não transmissíveis em adultos: estudo transversal, Brasil, 2011. Epidemiol. Serv. Saúde, Brasília , v. 22, n. 3, set. 2013. Disponível em: <http://dx.doi.org/10.5123/S1679-49742013000300007>. Acesso em: 07 dez. 2006.

MARASCHIN, J.F. et al . Classificação do diabete melito. Arq. Bras. Cardiol., São Paulo, v. 95, n. 2, p. 40-46, Ago. 2010. Disponível em: <http://dx.doi.org/10.1590/S0066-782X2010001200025 >. Acesso em: 13 mar. 2016.

MICHAELIS. Dicionário de Português Online. Editora Melhoramento Ltda, 2009. Disponível em: http://michaelis.uol.com.br/moderno/portugues/index .php?lingua=portugues-portugues\&palavra=experi\%EAncia. Acesso em: 24 abr. 2016.

MINAYO, M.C.S. O desafio do conhecimento: pesquisa qualitativa em saúde.4. ed. São Paulo: Hucitec-Abrasco, 1996. p 19-269.

MINAYO, MCS. O desafio do conhecimento: pesquisa qualitativa em saúde. 14 ed. São Paulo: Hucitec, 2014.

Trabalho de campo: contexto de observação, interação e descoberta. In: Deslandes SF, Gomes R, Minayo MCS, organizadora. Pesquisa social: teoria método e criatividade. Rio de Janeiro Vozes, 2007. p. 61- 77.

MOREIRA T.M.M, GOMES E.B, SANTOS J.C. Fatores de risco cardiovasculares em adultos jovens com hipertensão arterial e/ou diabetes mellitus. Rev Gaúcha Enferm., Porto Alegre (RS). v. 31, n. 4, p-662-9, 2010. Disponível em: < http://www.scielo.br/scielo.php?script=sci_arttext\&pid=S1983-14472010000400008>. Acesso em: 15 out. 2015.

MOREIRA, R.C. et al., Vivências em Família das necessidades de cuidados referentes à insulinoterapia e prevenção do pé diabético. Rev. Gaúcha Enfer. Porto Alegre, v. 29, n.2, p-283-91, jun. 2008. Disponível em: <http://seer.ufrgs.br/RevistaGauchade Enfermagem/article/view/5593>. Acesso em: 05 jan. 2016.

NAGAI, P.A;CHUBACI, R.Y.S. ; NERI, A.L. Idosos diabéticos: as motivações para o autocuidado. Revista Temática Kairós Gerontologia. São Paulo. v. 15, n.6, "Vulnerabilidade /Envelhecimento e Velhice: Aspectos Biopsicossociais", pp. 407-434. 
2012. Online. Disponível em: < file://C:/Users/Sandro/Downloads/17315-43184-1SM.pdf>. Acesso em: 20 dez. 2015.

NETTO, A.P. O impacto da fé no tratamento do diabetes. Sociedade Brasileira de Diabetes. Fev. 2016. Disponível em: < http://www.diabetes.org.br/ultimas/1253-oimpacto-da-fe-no-tratamento-do-diabetes>. Acesso em: 21 jun. 2016.

NOBREGA V.G, BEZERRA V.S. Identificação de eventos adversos relacionados a insulinoterapia em pacientes de cirurgia vascular. Rev. Bras. Farm. Hosp. Serv. Saúde. São Paulo v. 3 n.2 10-14 abr./jun. 2012. Disponível em: < http://www.sbrafh.org.br/rbfhss/public/artigos/2012030202BR.pdf>. Acesso em: 20 dez. 2015.

OLIVEIRA, J.E.P. et al . Aceitabilidade e funcionalidade de uma nova caneta para administração de insulina (Humapen®): experiência clínica em pacientes brasileiros.Arq Bras Endocrinol Metab, São Paulo, v. 44, n. 6, p. 519-522, Dec. 2000 . Disponível em: <http://www.scielo.br/scielo.php ?script=sci_arttext\&pid=S0004$27302000000600012 \& \mathrm{lng}=\mathrm{en} \& \mathrm{nrm}=\mathrm{iso}>$. Acesso em: 25 mai. $201 \overline{6}$.

OLIVEIRA, K.C.S, ZANETTI, M.L. Conhecimento e atitude de usuários com diabetes mellitus em um serviço de atenção básica à saúde. Rev. esc. enferm. USP. v. 45, n.4, p 862-8, 2011 Agosto: 862-868. Disponível em: < http://www.scielo.br/scielo.php?pid=S008062342011000400010\&script=sci arttext>.

Acesso em: 10 dez. 2015.

PEREIRA D.A et al. Efeito de intervenção educativa sobre o conhecimento da doença em pacientes com diabetes mellitus. Rev. Latino-Am. Enfermagem. Ribeirão Preto, v.20. n, 3, p. 478-485. Mai/Jun 2012. Disponível em: <http://www.scielo.br/scielo.php?pid=S0104-11692012000300008\&script=sci_ arttext\&tlng=pt>. Acesso em: 20 jan. 2016.

PÉRES, D.S. et al., Dificuldades dos pacientes diabéticos para o controle da doença: sentimentos e comportamentos. Rev. Latino-am Enfermagem, Ribeirão Preto, v.15, n.6, Nov/Dez 2007. Disponível em: <http://www.scielo.br/scielo.php?pid=S0104$11692007000600008 \&$ script=sci_arttext\&tlng=pt>. Acesso em: 03 fev. 2016.

PÉRES, D.S; FRANCO, L.J; SANTOS, M.A. Sentimentos de mulheres após o diagnóstico de Diabetes tipo 2. Rev. Latino-am. Enfermagem. v.16, n.1, 2008. Disponível em: < http://www.scielo.br/pdf/rlae/v16n1/pt_15.pdf>. Acesso em: 20 out. 2015.

PIANCASTELI, C.H; SPIRITO, G.C.; FLISH, T.M.P. Saúde do Adulto. Belo Horizonte: Nescon/UFMG, 2013. 166p. Disponível em: <https://www.nescon.medicina.ufmg.br/biblioteca/imagem/3999.pdf>. Acesso em: 05 dez 2015.

PIRES, M.R.G.M; GOTTEMS, L.B.D. Análise da gestão do cuidado no Programa de Saúde da Família: referencial teórico-metodológico. Rev. bras. enferm. 2009; 62(2): 294-299.

RAMOS, L.; FERREIRA, E.A.P. Fatores emocionais, qualidade de vida e adesão ao tratamento em adultos com diabetes tipo 2. Rev. bras. crescimento desenvolv. 
hum., São Paulo , v. 21, n. 3, p. 867-877, 2011 . Disponível em: <http://pepsic.bvsalud.org/scielo.php?script=sci_arttext\&pid=S0104-128220110 00300013\&lng=pt\&nrm=iso >. Acesso em: 11 mar. 2016.

REZENDE M.C.R.A et al. Impacto do controle glicêmico sobre as complicações associadas ao diabetes mellitus na osseintegração. Arch Health Invest. v. 3, n.3, p.73-81. 2014. Disponível em: < http://base.repositorio.unesp.br/bitstream/handle/11449/133226/ISSN2317-3009-201403-05-73-81.pdf? sequence=1\&isAllowed=>. Acesso em: 15 mar. 2016.

REZENDE, M.FC. Um estudo de caso sobre a experiência da doença de diabéticos tipo 2 usuários de uma unidade básica de saúde da família de Araguari-MG. 2010. 98f. Dissertação (Mestrado profissional em saúde pública) Fundação Oswaldo Cruz - Brasília-DF.

RODRIGUES, F.F.L. et al. Relação entre conhecimento, atitude, escolaridade e tempo de doença em indivíduos com diabetes mellitus. Acta paul. enferm., São Paulo, v. 25, n. 2, p. 284-290, 2012. Disponível em: <http://dx.doi.org/10.1590/S010321002012000200020>. Acesso em: 09 mar. 2016.

RODRIGUES, S.F. Os estilos de gestão do regime terapêutico e a sua influência nas atividades de autocuidado da população com diabetes mellitus tipo 2. 2014. 116f. Dissertação (Mestrado em Ciências de Enfermagem) - Instituto de Ciências Biomédicas Abel Salazar, Universidade do Porto-Portugal- Porto.

SAMPAIO, K. IBGE: renda per capita média do brasileiro atinge R\$ 1.113 em 2015. Agência Brasil. 2016. Disponível em: < http://agenciabrasil.ebc.com.br/economia/noticia/2016-02/ibge-renda-capita-media-dobrasileiro-atinge-r-1113-em-2015>. Acesso em: 21 jun. 2016.

SANTOS F.S, OLIVEIRA K.R, COLET C.F. Adesão ao tratamento medicamentoso pelos portadores de Diabetes Mellitus atendidos em uma Unidade Básica de Saúde no município de ljuí/RS: um estudo exploratório. Rev. Ciênc. Farm. Básica e Apl. Rio Grande do Sul, v.31, n.3, p. 223-227, 2010. Disponível em: <http://servbib.fcfar.unesp.br/seer/index.php/Cien_Farm /article/viewFile/1572/992>. Acesso em: 13 mar. 2016.

SANTOS, M.A. et al. Social representations of people with diabetes regarding their perception of family support for the treatment. Rev. esc. enferm. USP, São Paulo, v. 45, n. 3, p. 651-658, Jun. 2011 . Disponível em: <http://dx.doi.org/10.1590/S008062342011000300015>. Acesso em: 12 mar. 2016.

SANTOS, M.A.B. Avaliação da presença de transtornos ansiosos e qualidade de vida em pacientes com diabetes mellitus tipo 2 dependentes de insulina. 2013. 46f. Dissertação (Mestrado em Enfermagem)- Universidade do Extremo Sul Catarinense- Criciúma.

SBD, Diretrizes da Sociedade Brasileira de Diabetes: 2014-2015/ Sociedade Brasileira de Diabetes; [organização José Egidio Paulo de Oliveira, Sérgio Vencio]. São Paulo: AC. Farmacêutica, 2015. 
SBD, Sociedade Brasileira de Diabetes. Diretrizes da Sociedade Brasileira de Diabetes: 2013-2014. [organização José Egídio Paulo de Oliveira, Sérgio Vencio]. São Paulo: AC Farmacêutica (2014).

SCHMIDT, M.I. et al. Prevalência de diabetes e hipertensão no Brasil baseada em inquérito de morbidade auto-referida, Brasil, 2006. Rev. Saúde Pública, São Paulo , v. 43, supl. 2, p. 74-82, Nov. 2009 . Disponível em: <http://dx.doi.org/10.1590/S003489102009000900010>. Acesso em: 09 mar. 2016.

SELLIGMAN, H.K. et al. Food Insecurity is Associated with Hypoglycemia and Poor Diabetes Self-Management in a Low-IncomeSample with Diabetes. Journal Health Care Poor Underserved, v. 21, n. 4, p. 1227-1233, 2010. Disponível em: < http://dx.doi.org/ 10.1353/hpu.2010.0921>. Acesso em: 13 mar. 2016.

SEVERO, Denise de Sousa. Planejamento Urbano no Distrito Federal: O caso de Ceilândia. 2014. 89f. Dissertação (Departamento de Geografia), Universidade de Brasília, Brasília, Distrito Federal.

SILVA, E.N.S.F; SANTANA, P.S; PALMEIRA, C.S. Descarte de Seringas e Agulhas por Pacientes com Diabetes Mellitus. Revista Enfermagem Contemporânea, v. 2, n.1, p82-102, Ago. 2013. Disponível em: <http://www.bahiana.edu.br/revista>. Acesso em: 09 abr. 2015.

SILVA, M. E. D. C. et al. Resistência do homem às ações de saúde: percepção de enfermeiras da Estratégia Saúde da família. Revista Interdisciplinar NOVAFAPI. Teresina. V.3, n. 3, p. 21-25, Jul-Ago-Set. 2010. Disponível em: <http://www.novafapi.com.br/sistemas/revistainterdisciplinar/v3n3/pesquisa/p3_v3n3.pd f>. Acesso em: 06 mar. 2016.

SOARES, A.L; ARAÚJO, T.D; OLIVEIRA, J.S.A. Revisão de literatura sobre a desistência ao tratamento de diabetes mellitus. Rev. Científica da Escola de Saúde. Natal, Ano 3, n. 2, abr/set. 2014. Disponível em: <https://repositorio.unp.br/index.php/catussaba/ article/view/391>. Acesso em: 06 jan. 2016.

SOUZA ,A.A;SAD, P.N. Descarte do material perfurocortante por paciente insulino dependente [monografia] [internet]. Curitiba: Universidade Positivo; 2008. [acesso em 2011 ago 15]. Disponível em: <http://bvsms.saude.gov.br /bvs/publicacoes/premio2009/alessandra_aparecida.pdf>. Acesso em: 20 nov. 2015.

SOUZA C.R, ZANETTI M.L. Administração de insulina: uma abordagem fundamental na educação em diabetes. São Paulo. Rev. Esc. Enferm. USP, v.34, n.3, p.264-70, set. 2000. Disponível em: <http://www.scielo.br/pdf/reeusp/v34n3/v34n3a07>. Acesso em: 16 out. 2015.

STACCIARINI, T.S.G; CAETANO,T.S.G.; PACE,A.E. Dose de insulina prescrita versus dose de insulina aspirada. Acta paul. enferm., São Paulo , v. 24, n. 6, p. 789-793, 2011 . Disponível em: <http://dx.doi.org/10.1590/S0103-21002011000600010>. Acesso em: 12 mar. 2016.

STACCIARINI, T.S.G; PACE, A.E; IWAMOTO, H.H. Distribuição e utilização de seringas para aplicação de insulina na Estratégia Saúde da Família. Rev. Eletr. Enf. 
[Internef]. V. 12, n. 1, p- 47-55, 2010. Disponível em: < https://www.fen.ufg.br/fen_revista/v12/n1/v12n1a06.htm>. Acesso em: 30 nov. 2015.

STACCIARINI, T.S.G; PACE, A.E; HAAS, V.J. Técnica de autoaplicação de insulina com seringas descartáveis entre os usuários com diabetes mellitus, acompanhados pela estratégia saúde da família. Rev. Latino-Am. Enfermagem, Ribeirão Preto, v. 17, n. 4, p. 474-480, Ago. 2009. Disponível em: $<$ http://www.scielo.br/scielo.php?script=sci_arttext\&pid=S0104-11692009000400007 \&lng=en\&nrm=iso>. Acesso em: 05 jan. 2016.

TAPIA C.E.V. Diabetes mellitus e o descarte de seringas e agulhas. Rev Gaúcha Enferm.[internet]. v. 30, n. 2, p- 228-34, 2009. Disponível em: <http://seer.ufrgs.br/RevistaGauchadeEnfermagem/article/view/ 11310 /6696>. Acesso em: 21 out. 2015.

TAVARES, V.S et al. Avaliação da atenção ao diabetes mellitus em Unidades de Saúde da Família de Petrolina, Pernambuco, 2011. Epidemiol. Serv. Saúde, Brasília, v. 23, n.3, $p$ 527-536, jul-set 2014. Disponível em: $<$ http://scielo.iec.pa.gov.br/scielo.php?script=sci_arttext\&pid=S1679-497420140003 00015>. Acesso em: 26 fev. 2016.

THIRY- CHERQUES, H.R. Saturação em pesquisa qualitativa: estimativa empírica de dimensionamento. Af- Revista PMKT, p. 20-27, 2009. Disponível em: $<$ http://www.revistapmkt.com.br/Portals/9/Edicoes/Revista_PMKT_003_02.pdf>. Acesso em: 06 dez. 2015.

TORQUATO, T.M et al. Atuação do Enfermeiro no Serviço de Emergência na Assistência ao Cliente com Cetoacidose Diabética: Uma Revisão Bibliográfica. IN: 7ํ Mostra de Produção Científica da Pós-Graduação Lato Sensu da PUC, 2012, Goiânia. Caderno de artigos. Goiânia: PUC, 2012. Disponível em: < http://www.cpgls.pucgoias.edu.br/7mostra/Artigos/Caderno\%20de\%20Artigos\%207\%20 Mostra.pdf>. Acesso em: 01 dez. 2015.

TORQUATO, T.M. Conhecimento dos Clientes Diabéticos em Relação aos Cuidados com a Insulinoterapia. 2010. 57f. Monografia (Graduação em Enfermagem), Instituto de Ensino superior de Rio Verde - IESRIVER, Faculdade de Enfermagem, Rio Verde, Goiás.

TORQUATO, T; SANTOS, W; SANTA, T. Prática educativa de autocuidado para portadores de Diabetes Mellitus insulinotratados: revisão integrativa da literatura. CIAIQ2015, $\quad$ v. $1,2015.2$ Disponível em: < http://proceedings.ciaiq.org/index.php/ciaiq2015/article /view/8>. Acesso em: 10 fev. 2016.

TORRES H.C, PEREIRA F.R.L, ALEXANDRE L.R. Avaliação das ações educativas na promoção do autogerenciamento dos cuidados em diabetes mellitus tipo 2. Rev. esc. enferm. USP. v.45, n. 5, p.1077-82, Out, 2011. Disponível em: < http://www.scielo.br/scielo.php?script=sci arttext\&pid=S0080-62342011000500007>.

Acesso em: 27 nov. 2015.

TORRES, H.C et al. Monitoramento telefônico como estratégia educativa para o autocuidado das pessoas com diabetes na atenção primária. Cien. enferm. v.19, n.1, 
p:95-105, Nov, 2013. Disponível em: <http://www.scielo.cl/scielo.php?script=sci arttext\&pid=S0717-9553201300010>.

Acesso em: 30 nov. 2015.

TORRES, H.C et al., Capacitação de profissionais da atenção primária à saúde para educação em Diabetes Mellitus. Acta Paul Enferm. v.23, n.6, 2010. Disponível em: < http://www.scielo.br/pdf/ape/v23n6/06.pdf>. Acesso em: 10 jan. 2016.

VIGITEL. VIGITEL: diabetes 2011. Soc. Bras. End. Met.. Fev. 2011. Disponível em: < http://www.endocrino.org.br/vigitel-2011-diabetes/. Acesso em: 10 set. 2015.

VILLAS BOAS, L.C.G et al. Relação entre apoio social, adesão aos tratamentos e controle metabólico de pessoas com diabetes mellitus. Rev. Latino-Am, Enfermagem. v. 20, n.1 jan-fev, 2012. Disponível em:< http://www.scielo.br/pdf/rlae/v20n1/pt_08.pdf>. Acesso em: 16 out. 2015.

VILLAS BOAS, L.C.G; LIMA, M.L.S.A.P; PACE, A.E. Adesão ao tratamento do diabetes mellitus: validação de instrumentos para antidiabéticos orais e insulina. Revista LatinoAm. Enfermagem. v. 22, n. 1, jan,-fev, 2014. Disponível em: $<$ http://www.scielo.br/pdf/rlae/v22n1/pt_0104-1169-rlae-22-01-00011.pdf>. Acesso em: 06 dez 2015.

WISNESKY, U.D et al. Insulinoterapia: o reuso de seringas descartáveis por pacientes diabéticos. Perspectivas Médicas, v. 25, n. 2, p-5-12, mai/ago. 2014. Disponível em: < http://www.redalyc.org/pdf/2432/243231714002.pdf>. Acesso em: $21 \mathrm{dez} 2015$.

ZANDONÁ, T.; OLIVEIRA, T.B. Perfil dos pacientes diabéticos tipo 2 que utilizam antidiabéticos orais. Rev. Bras. Farm, Rio Grande do Sul, v. 93, n. 4, p. 476-480, 2012. Disponível em: <http://www.rbfarma.org.br/files/rbf-2012-93-4-13.pdf>. Acesso em: 12 mar. 2016 


\section{APÊNDICE I}

\section{Termo de Consentimento Livre e Esclarecido - TCLE}

$\mathrm{O}(\mathrm{A})$ senhor(a) está sendo convidado a participar do projeto de pesquisa "Experiência de pessoas que vivem com diabetes e insulinotratadas, atendidas em Regional Administrativa do Distrito Federal". A pesquisa tem por objetivo investigar a experiência de viver com diabetes utilizando a insulina como elemento da terapêutica e que são atendidos em Regional Administrativa do Distrito Federal.

$\mathrm{O}(\mathrm{A})$ senhor(a) receberá os esclarecimentos necessários antes e no decorrer da pesquisa, e lhe asseguramos que seu nome será mantido sob rigoroso sigilo por meio da omissão total de quaisquer informações que permitam identificá-lo(a).

A sua participação será por meio de uma entrevista que irá responder em um ambiente propício e favorável em data combinada, com um tempo estimado de 30 minutos, sendo respeitado o seu tempo para essa conversa. Informamos que o senhor(a) pode se recusar a responder qualquer questão que the traga constrangimento, podendo desistir de participar da pesquisa em qualquer momento, sem nenhum prejuízo para o(a) senhor(a).

$\mathrm{O}(\mathrm{A})$ senhor(a) estará exposto a riscos mínimos, podendo sentir algum incômodo em ter que compartilhar informações pessoais e ao presenciar a gravação de suas falas.

O desenvolvimento desse estudo será de suma importância, pois ele poderá servir de subsídio para a elaboração de planos de cuidados específicos voltados às necessidades do grupo de estudo, facilitando o atendimento em saúde com a orientação de pessoas em relação à insulinoterapia e, consequentemente, diminuindo as complicações decorrentes dessa patologia.

Os resultados da pesquisa serão divulgados na Universidade de Brasília Faculdade de Ciências da Saúde, podendo ser publicados posteriormente em revistas e apresentados em encontros científicos. Os dados e materiais utilizados na pesquisa ficarão sob a guarda do pesquisador responsável.

Se o senhor tiver qualquer dúvida em relação à pesquisa, por favor, entrar em contato com: Esp. ${ }^{\text {a }}$ Thatiane Marques Torquato, pelo telefone: (61) 92548529, no horário comercial, e pelo email: thatiane.torquato@ifg.edu.br. Este projeto foi Aprovado 
pelo Comitê de Ética em Pesquisa da SES/DF. As dúvidas com relação à assinatura do TCLE ou os direitos do sujeito da pesquisa podem ser obtidos pelo telefone: (61) 3325-4955. Este documento foi elaborado em duas vias, uma ficará com o pesquisador responsável e a outra com o sujeito da pesquisa. Agradecemos sua colaboração.

Nome / assinatura

Esp. ${ }^{\mathrm{a}}$ Thatiane Marques Torquato

Pesquisadora Responsável

Brasília (Ceilândia/DF), de de 


\section{APÊNDICE II}

\section{Questões Iniciais - Perfil sociodemográfico}

Idade:

( ) 20 a 29 anos

( ) 30 a 39 anos

( ) 40 a 49 anos

( ) 50 a 59 anos

( ) 60 anos ou mais

\section{Estado Conjugal:}
( ) solteiro
( ) casado
( ) divorciado
( ) viúvo

Nível de Escolaridade:

( ) Não Alfabetizado

( ) Ensino Fundamental Incompleto

( ) Ensino Fundamental

( ) Ensino Médio

( ) Ensino Médio Incompleto

( ) Ensino Superior incompleto

( ) Ensino Superior completo

Profissão:

\section{Renda Familiar:}

( ) Até 1 salário mínimo. [R $\$ 788,06]$

( ) 2 a 3 salários mínimos. [R $\$ 1.576,12$ a 2.364,18]

( ) 4 a 6 salários mínimos. [R $\$$ 3.152,24 a 4.728,36]

( ) Mais que 6 salários mínimos. [acima de $R \$ 4.728,36$ ] 


\section{Questões Iniciais da Entrevista}

Tipos de diabetes? Diabetes: Tipo 1 ( ) Tipo 2 ( )

Tempo de diagnóstico:

Tempo de insulinoterapia: :

Tipo de Insulina utilizada: :

Dosagem de insulina utilizada:

\section{Questão Norteadora da Entrevista}

11- Descreva-me a experiência de viver com diabetes e realizar o uso de insulina? 


\section{APÊNDICE III}

\begin{tabular}{|c|c|c|c|}
\hline \multicolumn{4}{|c|}{ CHECKLIST DE ORIENTAÇÕES RELACIONADAS À INSULINOTERAPIA } \\
\hline \multirow[t]{2}{*}{ Orientações realizadas pelo enfermeiro } & \multicolumn{3}{|c|}{ Procedimento executado pelo usuário } \\
\hline & Acertou & $\begin{array}{l}\text { Apresentou } \\
\text { dificuldade }\end{array}$ & $\begin{array}{l}\text { Não soube } \\
\text { realizar }\end{array}$ \\
\hline $\begin{array}{l}\square \text { Informar sobre a retirada da insulina da } \\
\text { geladeira e aguardar de } 15 \text { a } 30 \text { minutos para } \\
\text { preparar a insulina }\end{array}$ & & & \\
\hline $\begin{array}{c}\square \quad \text { Observar o aspecto da insulina e sua } \\
\text { validade (conforme o fabricante caso lacrada } \\
\text { ou até seis semanas após aberta) }\end{array}$ & & & \\
\hline$\square \quad$ Realizar a higienização das mãos & & & \\
\hline$\square \quad$ Homogeneizar a insulina & & & \\
\hline $\begin{array}{l}\square \text { Limpar a borracha do frasco de insulina } \\
\text { com álcool a 70\% e esperar secar (não soprar) }\end{array}$ & & & \\
\hline $\begin{array}{c}\square \text { Aspirar o ar até a quantidade prescrita de } \\
\text { insulina }\end{array}$ & & & \\
\hline$\square$ Injete o ar dentro do frasco da insulina & & & \\
\hline $\begin{array}{c}\square \text { Aspire a quantidade de insulina prescrita } \\
\text { e verifique se há ar na seringa, se houver, } \\
\text { injete a insulina de volta para o frasco e } \\
\text { aspire novamente }\end{array}$ & & & \\
\hline $\begin{array}{l}\square \text { Verifique se a dosagem está conforme a } \\
\text { prescrição médica }\end{array}$ & & & \\
\hline $\begin{array}{l}\text { Retire a agulha do frasco e cubra- a com o } \\
\text { seu protetor }\end{array}$ & & & \\
\hline Aplicação da insulina & Acertou & $\begin{array}{l}\text { Apresentou } \\
\text { dificuldade }\end{array}$ & $\begin{array}{l}\text { Não soube } \\
\text { realizar }\end{array}$ \\
\hline $\begin{array}{l}\text { Escolher o local para a realização da } \\
\text { insulina, explicar sobre o rodízio e ensinar a } \\
\text { técnica de autoaplicação da insulina em todas }\end{array}$ & & & \\
\hline
\end{tabular}




\begin{tabular}{|c|c|c|c|}
\hline as regiões & & & \\
\hline$\square$ Realizar a assepsia do local de aplicação & & & \\
\hline Faça a prega cutânea & & & \\
\hline $\begin{array}{c}\square \quad \text { Introduza a agulha a } 90^{\circ} \text { e solte a prega } \\
\text { cutânea }\end{array}$ & & & \\
\hline$\square \quad$ Injete toda a insulina da seringa & & & \\
\hline $\begin{array}{l}\square \quad \text { Retire a agulha e pressione o local por } \\
\text { alguns segundo com algodão sem massagear }\end{array}$ & & & \\
\hline Armazenamento e transporte da insulina & Acertou & $\begin{array}{l}\text { Apresentou } \\
\text { dificuldade }\end{array}$ & $\begin{array}{l}\text { Não soube } \\
\text { realizar }\end{array}$ \\
\hline $\begin{array}{c}\square \quad \begin{array}{c}\text { Orientação sobre a temperatura correta } \\
\text { de armazenamento da insulina }\end{array}\end{array}$ & & & \\
\hline $\begin{array}{c}\square \quad \begin{array}{c}\text { Explicar sobre os possíveis locais de } \\
\text { armazenamento da insulina }\end{array}\end{array}$ & & & \\
\hline $\begin{array}{c}\square \quad \text { Orientar sobre o transporte de insulina } \\
\text { em pequena distância }\end{array}$ & & & \\
\hline $\begin{array}{c}\square \quad \text { Orientar sobre o transporte da insulina } \\
\text { em longa distância }\end{array}$ & & & \\
\hline
\end{tabular}




\section{ANEXO I}

\section{APROVAÇÃO DO PROJETO DE PESQUISA PELO COMITÊ DE ÉTICA}

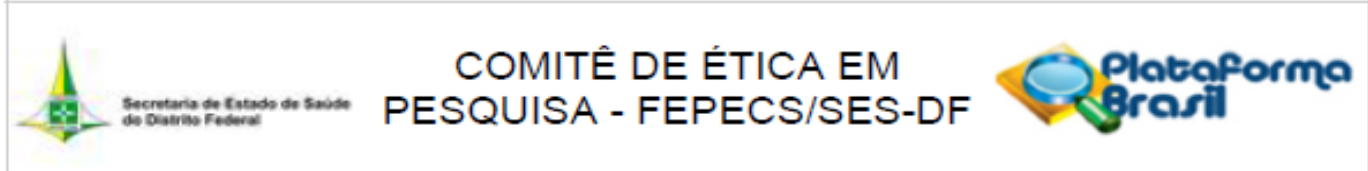

Continuaçäo do Parecer. 1.037.214

Regional Administrativa do Distrito Federal.

Específicos:

- Conhecer o perfil de pessoas que vivem com diabetes insulinotratados atendidos em Regional Administrativa do Distrito Federal.

- Compreender a experiência de administração de insulina para pessoas que vivem com diabetes atendidos em Regional Administrativa do Distrito Federal.

- Identificar as dificuldades apontadas no manejo do DM e no uso da insulina pelas pessoas que vivem com diabetes atendidos em Regional Administrativa do Distrito Federal.

Avaliação dos Riscos e Benefícios:

Os sujeitos foram adequadamente identificados. Foram apresentados os riscos e benefícios. Com os benefícios, espera-se que sejam elaborados planos de cuidados específicos voltados às necessidades do grupo de estudo, facilitando o atendimento em saúde com a orientação de pessoas em relação à insulinoterapia e, consequentemente, diminuindo as complicações decorrentes da patologia estudada. Os antecedentes científicos que justificam a pesquisa foram apresentados.

Comentários e Considerações sobre a Pesquisa:

A pesquisa refere-se a um Trabalho de Mestrado em Enfermagem. Trata-se de um estudo com abordagem qualitativa, que será realizado no Centro de Saúde 06 da Regional Administrativa de Saúde de Ceilândia/SES/DF.

Os sujeitos de pesquisa serão de 10 a 15 indivíduos que realizam tratamento de Diabetes Mellitus, cadastrados e acompanhados pela equipe de saúde do referido Centro de Saúde, que estão no mínimo há um ano em insulinoterapia, que praticam o automanejo da insulina, com idades acima de 18 anos.

A coleta de dados será realizada através de uma entrevista semi-estruturada composta por dados de identificação dos sujeitos e a seguinte questão norteadora: Descreva-me a experiência de viver com diabetes e realizar o uso de insulina?

As entrevistas gravadas serão transcritas pelo pesquisador e em seguida serão submetidos à Análise de Conteúdo, na modalidade temática.

Endereço: SMHN 2 Qd 501 BLOCO A - FEPECS

Bairro: ASA NORTE

UF: DF Município: BRASILIA

CEP: $70.710-904$

Telefone: (61)3325-4955 Fax: (33)3325-4955 E-mail: comitedeetica.secretaria@gmail.com 


\section{COMITÊ DE ÉTICA EM
PESQUISA - FEPECS/SES-DF Plotoforma}

Continuaçäo do Parecer. 1.037.214

Considerações sobre os Termos de apresentação obrigatória:

Folha de rosto: Apresentada. Documento assinado pelo Coordenador Geral de Saúde de Ceilândia/HRC/SES/DF.

Termo de Concordância: Apresentado. Documento assinado pelo Diretora e Responsável pela Unidade Clínica do Centro de Saúde $n^{\circ} 06$ da Regional de Saúde de Ceilândia/SES/DF.

Curriculum Vitae do(s) pesquisador(es): Apresentados.

Cronograma da Pesquisa: Apresentado.

Planilha de orçamento: Apresentada.

TCLE: Apresentado.

Critérios de Inclusão e Exclusão: Definidos.

\section{Recomendaçōes:}

O pesquisador assume o compromisso de garantir o sigilo que assegure o anonimato e a privacidade dos sujeitos da pesquisa e a confidencialidade dos dados coletados. Os dados obtidos na pesquisa deverão ser utilizados exclusivamente para a finalidade prevista no seu protocolo, que só poderá iniciar após aprovação pelo CEP/FEPECS/SES/DF.

O pesquisador deverá encaminhar relatório parcial e final de acordo com o desenvolvimento do projeto da pesquisa,

Conclusōes ou Pendências e Lista de Inadequações:

- Projeto Aprovado.

\section{Situação do Parecer:}

Aprovado

Necessita Apreciação da CONEP:

Não

Considerações Finais a critério do CEP:

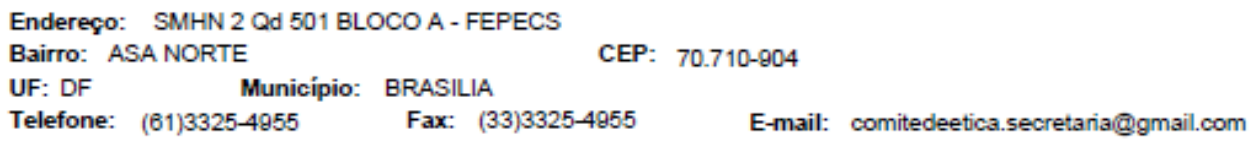




\section{COMITÊ DE ÉTICA EM PESQUISA - FEPECS/SES-DF

\section{Prasil}

Continuaçäo do Parecer: 1.037.214

BRASILIA, 27 de Abril de 2015

Assinado por:

Helio Bergo

(Coordenador) 
ANEXO II

COMPROVANTE DE SUBMISSÃO DO ARTIGO NA REVISTA DE SAÚDE PÚBLICA

$24 / 05 / 2016$

Mensagem de Impressão do Outlook.com

$\underline{\text { Imprimir }}$

$\underline{\text { Fechar }}$

\section{RSP - Confirmacao do recebimento de artigo}

De: $\quad$ RSP (rspline@fsp.usp.br)

Enviada: terça-feira, 1 de março de 2016 10:39:44

Para: Thatiane Marques Torquato (th4thy@hotmail.com)

Prezado(a) Senhor(a) Thatiane Marques Torquato,

Acusamos o recebimento do artigo "Seringas descartáveis para insulinoterapia: já que são descartáve reutilizar?", enviado para análise na Revista de Saúde Pública, com vista a possível publicação. O ar1 sob o protocolo $n^{\circ} 6993$

Para acompanhar o processo de avaliação, acesse o endereço www.rsp.fsp.usp.br

Atenciosamente,

Secretaria RSP 